MICHEL CAMACHO ROULET

UMA APLICAÇÃO DE ANÁLISE MULTICRITÉRIO PARA A COORDENAÇÃO VERTICAL NO TRANSPORTE DE GRANÉIS SÓLIDOS AGRÍCOLAS

\author{
Dissertação apresentada à Escola \\ Politécnica da Universidade de São \\ Paulo para obtenção do Título de \\ Mestre em Engenharia de Sistemas \\ Logísticos
}

São Paulo 
MICHEL CAMACHO ROULET

UMA APLICAÇÃO DE ANÁLISE MULTICRITÉRIO PARA A COORDENAÇÃO VERTICAL NO TRANSPORTE DE GRANÉIS SÓLIDOS AGRÍCOLAS

Dissertação apresentada à Escola Politécnica da Universidade de São Paulo para obtenção do Título de Mestre em Engenharia de Sistemas Logísticos

Área de concentração:

Engenharia de Sistemas Logísticos

Orientador: Prof. Dr.

José Vicente Caixeta-Filho

São Paulo 
Este exemplar foi revisado e corrigido em relação à versão original, sob responsabilidade única do autor e com a anuência de seu orientador.

São Paulo, 05 de janeiro de 2015.

Assinatura do autor

Assinatura do orientador

Catalogação-na-publicação

Roulet, Michel Camacho

Uma aplicação de análise multicritério para a coordenação vertical no transporte de granéis sólicods agrícolas / M.C.

Roulet. -- versão corr. -- São Paulo, 2015.

$110 \mathrm{p}$.

Dissertação (Mestrado) - Escola Politécnica da Universidade de São Paulo. Departamento de Engenharia de Transportes.

Sistemas Logísticos.

1.Transporte de carga 2.Produtos agrícolas 3.Análise multicritérios I.Universidade de São Paulo. Escola Politécnica. Departamento de Engenharia de Transportes II.t. 


\section{DEDICATÓRIA}

Dedico este trabalho ao Senhor que tem me guiado durante a minha vida, à minha esposa Stephanie Dias Roulet e à minha filha Louise Marie Roulet que está à caminho. Também dedico aos meus pais, Jacques Alain Roulet e Patrícia Camacho Roulet, pelo exemplo que são em minha vida. 


\section{AGRADECIMENTOS}

Agradeço a Deus por me guiar diante dos caminhos e escolhas durante a minha vida, que continue a me abençoar e me orientar por toda a eternidade.

À minha esposa que amo Stephanie Dias Roulet, que esteve sempre ao meu lado, me estimulando, desafiando e reconhecendo todo o esforço realizado. E que depois de tudo concluído me presenteou com uma bebê maravilhosa que será a realização dos nossos sonhos e a alegria de nossas vidas.

À minha família, pais, avós, tios, sogros e cunhados, que sempre me apoiaram, ajudaram e compreenderam a dedicação que tive que entregar ao programa e que entenderam que muitas vezes não pude ceder todo o meu tempo a aqueles que realmente me amam mas que sabem que este precioso tempo foi muito importante para mim.

Ao meu orientador desde a graduação e também no mestrado Prof. Dr. José Vicente Caixeta-Filho, que dedicou o seu tempo, paciência, confiança e seus valiosos conselhos para a conclusão do curso. Agradeço também aos membros da banca, Dr. Hugo Tsugunobu Yoshida Yoshizaki e Dr. Augusto Hauber Gameiro, pelas críticas construtivas para a finalização da dissertação. Também agradeço ao Irineu Brito pela ajuda na aplicação final do modelo.

Aos meus colegas de trabalho e demais 'logistiqueiros' que sempre me ensinaram muito sobre logística, em especial ao meu chefe Rodrigo Koelle pela confiança depositada e a liderança da empresa que tem apoiado minhas ideias e projetos.

À Escola Politécnica (POLI) e Escola Superior de Agricultura 'Luiz de Queiroz' (ESALQ) e toda a equipe de professores que promoveram um ambiente desafiador e estimulante de aprendizado, assim como é na Universidade de São Paulo. Também agradeço aos colegas e amigos do programa que sempre me ajudaram e conviveram comigo nos trabalhos, dúvidas e outros momentos de estudo para adquirir este conhecimento valiosíssimo. 


\section{SUMÁRIO}

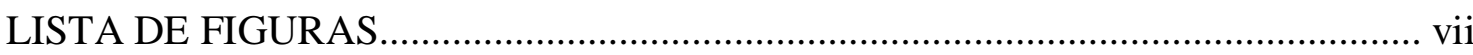

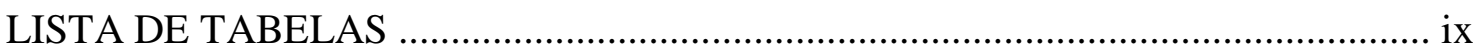

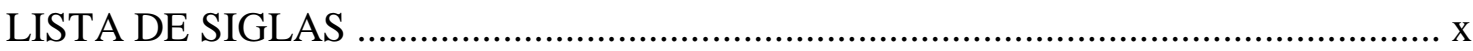

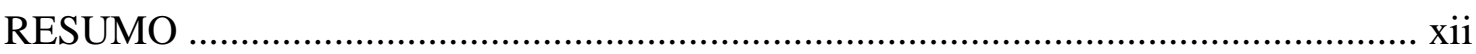

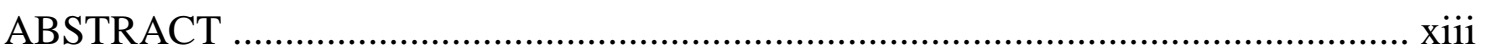

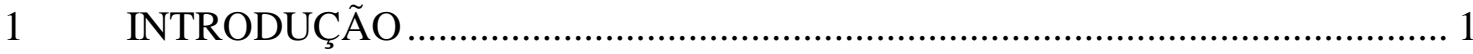

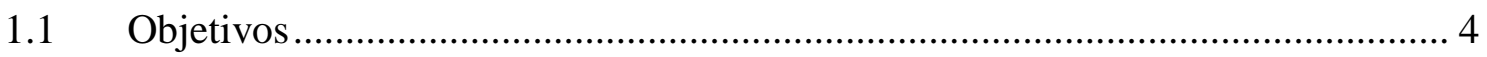

1.2 Organização da dissertação........................................................................ 5

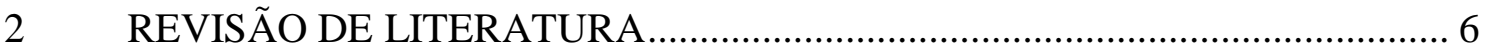

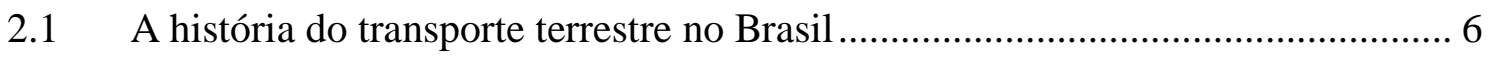

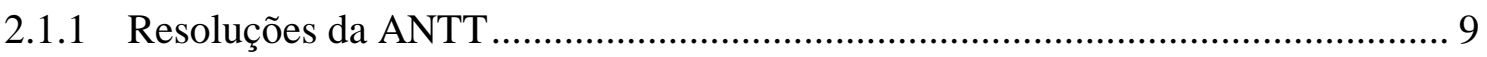

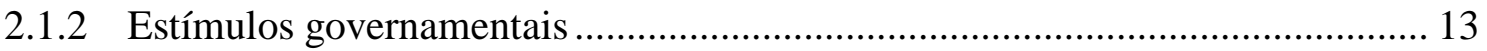

2.2 A economia dos custos de transação................................................................. 15

2.3 Caracterização do sistema de transporte rodoviário pela ótica de ECT ............. 19

2.4 Aplicação de Seguros no transporte de cargas.................................................. 23

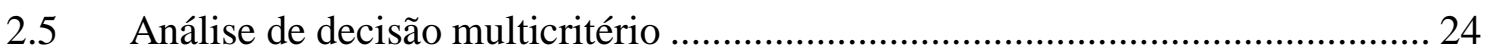

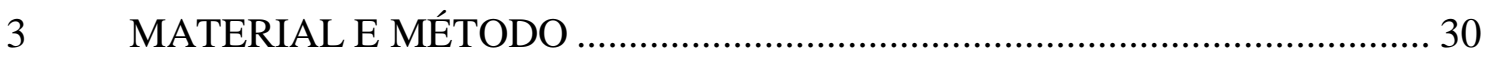

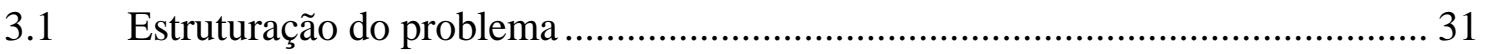

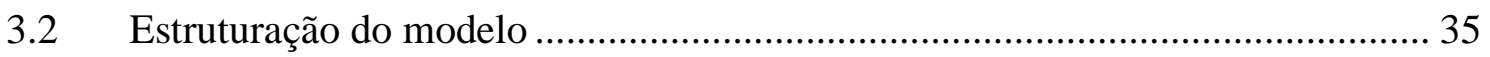

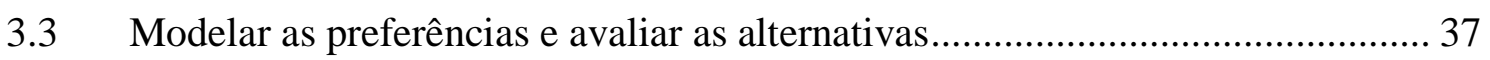

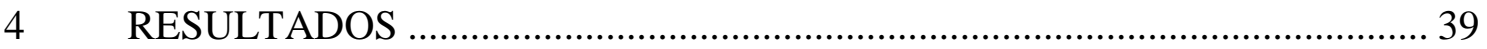




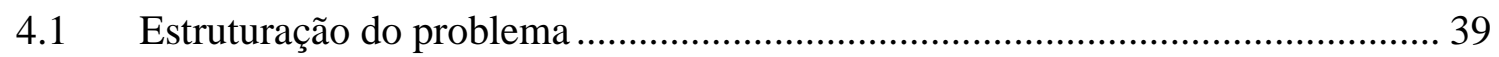

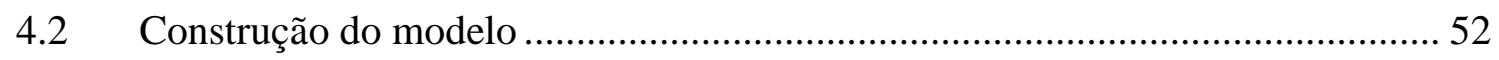

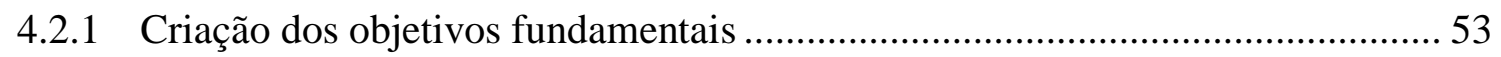

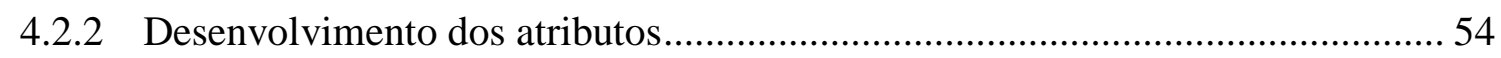

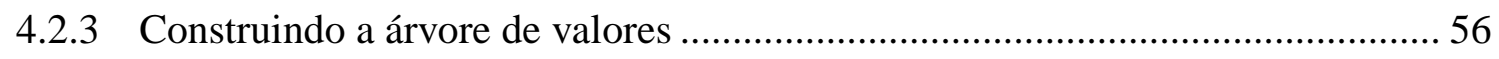

4.3 Modelar as preferências e avaliar as alternativas............................................. 57

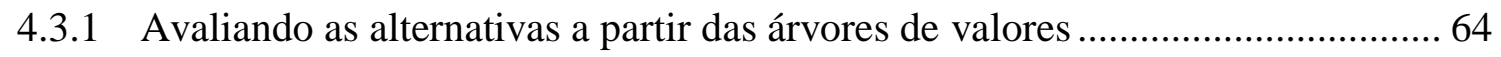

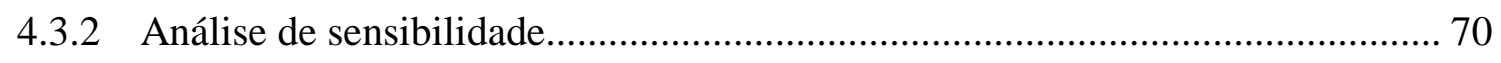

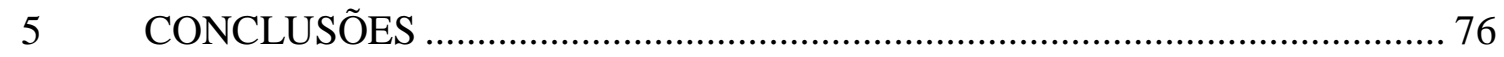

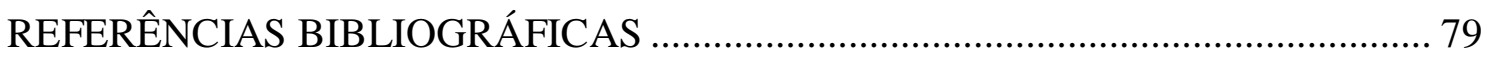

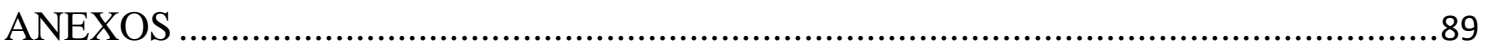




\section{LISTA DE FIGURAS}

Figura 01 - Matriz de Transportes proposta pelo PNLT (PERRUPATO, 2012 slide 43). 14

Figura 02 - Programa de expansão ferroviária (PERRUPATO, 2012, slide 53)..... .15

Figura 03 - Custos de governança em função da especificidade dos ativos (WILLIAMSON, 1991, p. 108).

Figura 04 - Forma organizacional em resposta a mudanças na frequência dos distúrbios (WILLIAMSON, 1991, p. 117). .18

Figura 05 - Veículo autodescarregável do tipo Hopper (PASTRE, 2013) 20

Figura 06 - Veículo autodescarregável do tipo Basculante (PASTRE, 2013)...... .20

Figura 07 - Estruturação do processo de MCDA (adaptado e traduzido a partir de Franco e Montibeller (2010) .25

Figura 08 - Sequenciamento das abordagens AFT e VFT, adaptado a partir de Parnell et al. (2008) .29

Figura 09 - Fases de desenvolvimento do trabalho .30

Figura 10 - Mapa cognitivo do problema proposto com base no processo MCDA.......34

Figura 11 - Auto Posto Locatelli em Rondonópolis .43

Figura 12 - Detalhe da sala da Transportadora da Amaggi...... .44

Figura 13 - Fluxograma da subcontratação de transporte (elaborado pelo autor)..........46

Figura 14 - Trade-off Custo x Benefício observado no ambiente da Trading .49

Figura 15 - Ponderação Custo x Benefício do modelo .53

Figura 16 - Ponderação dos atributos do subcritério Benefício .56

Figura 17 - Árvore de valores do modelo proposto .57

Figura 18 - Curva de valor para o subcritério Custo. .58 
Figura 19 - Curva de valor para o atributo Atendimento da demanda.

Figura 20 - Curva de valor para o atributo Adequação de frota.

Figura 21 - Curva de valor para o atributo Gestão e controle.

Figura 22 - Curva de valor para o atributo Capacidade de inovação .62

Figura 23 - Curva de valor para o atributo Know-how adquirido.

Figura 24 - Desempenho global das alternativas. .64

Figura 25 - Desempenho parcial dos subcritérios Custo e Benefício .65

Figura 26 - Trade-off Custo x Benefício .66

Figura 27 - Desempenho das estratégias para subcritério Custo.

Figura 28 - Desempenho das estratégias para o subcritério Benefício .67

Figura 29 - Desempenho parcial para os atributos do subcritério Benefício .68

Figura 30 - Trade-offs da relação Benefício x Atributos. .69

Figura 31 - Trade-offs da relação Custo x Atributos dos Benefícios. .70

Figura 32 - Análise de sensibilidade da decisão em relação a Custo. .71

Figura 33 - Análise de sensibilidade da decisão em relação a Benefício. . .72

Figura 34 - Árvore de valores da primeira variação .73

Figura 35 - Desempenho global da primeira variação................................................73

Figura 36 - Árvore de valores da segunda variação.....................................................74

Figura 37 - Desempenho global da segunda variação.................................................74 


\section{LISTA DE TABELAS}

Tabela 01 - Aspectos importantes para descrição do problema, adaptado de Belton e

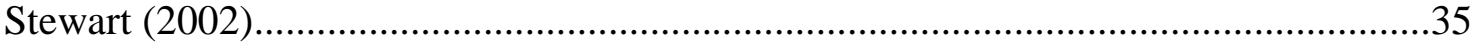

Tabela 02 - Estratégias de verticalização observadas nas entrevistas.............................40

Tabela 03 - Construção da curva de valor para o subcritério Custo...............................58

Tabela 04 - Construção da curva de valor para o atributo Atendimento da demanda....59

Tabela 05 - Construção da curva de valor para o atributo Adequação de frota...............60

Tabela 06 - Construção da curva de valor para o atributo Gestão e controle.................61

Tabela 07 - Construção da curva de valor para o atributo Capacidade de inovação......62

Tabela 08 - Construção da curva de valor para o atributo Know-how adquirido...........63

Tabela 09 - Desempenho atribuído a cada estratégia...................................................64

Tabela 10 - Composição do desempenho para cada estratégia......................................66 


\section{LISTA DE SIGLAS}

ABIOVE - Associação Brasileira das Indústrias de Óleos Vegetais e Biodiesel AFT-Alternative Focused Thinking

ANEC - Associação Nacional dos Exportadores de Cereais

ANFAVEA - Associação Nacional dos Fabricantes de Veículos Automotores

ANFIR - Associação Nacional dos Fabricantes de Implementos Rodoviários

ANTAQ - Agência Nacional de Transporte Aquaviário

ANTT - Agência Nacional de Transportes Terrestres

BNDES - Banco Nacional do Desenvolvimento Econômico e Social

CIOT - Código Identificador de Operação de Transporte

CLT - Consolidação das Leis do Trabalho

CTC - Cooperativas de Transporte de Carga

CT-e - Conhecimento de Transporte eletrônico

DACTE - Documento Auxiliar do Conhecimento de Transporte Eletrônico

DANFE - Documento Auxiliar da Nota Fiscal Eletrônica

DNIT - Departamento Nacional de Infraestrutura e Transportes

ECT - Economia dos Custos de Transação

EPL - Empresa de Planejamento e Logística

ESALQ-LOG - Grupo de Pesquisa e Extensão em Logística Agroindustrial

ETC - Empresas de Transporte de Carga

FINAME - Financiamento Nacional de Máquinas e Equipamentos

ILOS - Instituto de Logística e Supply Chain 
IPI - Imposto sobre Produto Industrializado

MCDA - Multiple Criterial Decision Analisys (Análise de Decisão Multicritério)

MDF-e - Manifesto Eletrônico de Documentos Fiscais

NF-e - Nota Fiscal eletrônica

NTC - Associação Nacional do Transporte de Cargas e Logística

PAC - Programa de Aceleração do Crescimento

PEF - Pagamento Eletrônico de Frete

PIB - Produto Interno Bruto

PNLT - Plano Nacional de Logística e Transportes

RCF-DC - Responsabilidade Civil Facultativo por Desaparecimento de Carga

RCTRC-C - Responsabilidade Civil do Transportador Rodoviário de Cargas

RFFSA - Rede Ferroviária Federal Sociedade Anônima

RNTRC - Registro Nacional de Transporte Rodoviário de Cargas

RR - Risco Rodoviário

SIFRECA - Sistema de Informações de Fretes de Cargas Agrícolas

SPED - Sistema Público de Escrituração Digital

SLA - Service Level Agreement - Acordo de Nível de serviço

TAC - Transportador Autônomo de Cargas

TRC - Transporte Rodoviário de Cargas

V.I.S.A. - Virtual Instrument Software Architecture

VFT - Value Focused Thinking 


\title{
UMA APLICAÇÃO DE ANÁLISE MULTICRITÉRIO PARA A COORDENAÇÃO VERTICAL NO TRANSPORTE DE GRANÉIS SÓLIDOS AGRÍCOLAS
}

\author{
Autor: MICHEL CAMACHO ROULET \\ Orientador: Prof. Dr. JOSÉ VICENTE CAIXETA-FILHO
}

\section{RESUMO}

As estratégias para executar o transporte rodoviário de granéis sólidos agrícolas no Brasil são um desafio à tomada de decisão. Este trabalho emprega a coordenação vertical e a análise da decisão para apresentar uma discussão acerca do processo decisório nas organizações. O método de análise multicritério, baseado em curvas de valor, permite a comparação de arranjos de governança em situações específicas. Para isso, foram definidos os principais objetivos, critérios e variáveis dos problemas de verticalização no transporte, e os resultados obtidos apontaram que o transporte verticalizado apresentou pior desempenho do que alternativas híbridas ou terceirizadas. Tal resultado suporta que em ambientes com alta dependência de custos e com baixa especificidade do ativo há maior tendência de se encontrar estruturas híbridas ou coordenadas via mercado. O levantamento descritivo do transporte rodoviário com empresas embarcadoras de cargas agrícolas bem como o resultado do modelo multicritério aplicado apontaram um mercado de transporte altamente terceirizado, que seria fomentado pela atual incerteza e baixa profissionalização dos transportadores rodoviários. À medida que a diferença de preços entre o modelo terceirizado e verticalizado diminui, há preferência pela estrutura hierárquica, dado o seu melhor desempenho nos benefícios oferecidos. Diante das mudanças no ambiente institucional, tal como a regulamentação dos transportes, os arranjos competitivos podem sofrer alterações. Para os tomadores de decisão, as estruturas verticalizadas poderiam compor com maior escala as estratégias das embarcadoras à medida que os custos da operação própria se aproximem dos valores praticados pelas transportadoras.

Palavras-chave: transporte rodoviário, coordenação vertical, análise da decisão, logística, regulamentação dos transportes. 


\title{
A MULTIPLE CRITERIAL ANALYSIS APPLICATION FOR VERTICAL COORDINATION IN THE TRANSPORTATION OFAGRICULTURAL COMMODITIES
}

\author{
Author: MICHEL CAMACHO ROULET \\ Advisor: Prof. Dr. JOSÉ VICENTE CAIXETA-FILHO
}

\begin{abstract}
The strategies to perform the transportation of agricultural commodities by truck in Brazil are a challenge to decision making. This paper brings together vertical coordination and decision analysis, to present a discussion of decision making in organizations. The Multiple Criterial Decision Analisys (MCDA), method based on value functions, allows comparison of governance arrangements in specific situations. After define the main objectives, criteria and variables found in transport verticalization problems, the results showed worse performance of verticalized arrengements than hybrid or outsourced alternatives. This result supports that in environments with high dependence on low costs and asset low specificity are more likely to meet hybrid or market coordinated structures. However, the descriptive survey of road transport with agricultural shippers and the results of the multicriterial model indicated a highly outsourced transport market, which would be fostered by the current uncertainty and low professionalism of haulers. As the price difference between the outsourced model and vertical decreases there is a preference for hierarchical structure given his best performances in the benefits offered. Given the changes in the institutional environment, such as the transport regulation, competitive arrangements may change. This type of preference by decision makers would compose the vertical structures with more scale strategies by shippers.
\end{abstract}

Keywords: truck transport, vertical coordination, decision analysis, logistics, transport regulations. 


\section{INTRODUÇÃO}

A coordenação vertical pode ser observada em determinadas cadeias de suprimentos, e reflete padrões de governança entre os agentes atuantes. No agronegócio, as empresas possuem diversos modelos de integração vertical e, no caso do transporte de granéis sólidos agrícolas, esta característica é relevante para a tomada de decisões estratégicas.

O presente trabalho propõe-se a auxiliar a tomada de decisão através de um modelo fundamentado na teoria de coordenação vertical (WILLIAMSON, 1989; ZYLBERSZTAJN; 1995) combinado com o método de análise da decisão multicritério (BELTON e STEWART, 2002; FRANCO e MONTIBELLER, 2010). Para isso, serão abordados e discutidos os principais trade-offs enfrentados durante o processo decisório de integração vertical no transporte rodoviário, propondo-se ao final do estudo estruturar a decisão de uma empresa na escolha do melhor arranjo competitivo para suas necessidades.

Enquanto a produção de grãos no Brasil destaca-se mundialmente pela alta produtividade e pela ocorrência de pelo menos duas safras anuais, a deficiência logística em todo o sistema agroindustrial é um grande desafio. O efeito logístico afeta diretamente os custos de produção bem como a valorização dos produtos nas unidades agroindustriais, uma vez que a precificação mais comum para as commodities agrícolas é a cotação do grão no mercado internacional, descontados os custos de frete. A coordenação vertical tem como objetivo a minimização dos custos de transação e pode tornar-se eficiente à medida que o ambiente institucional promova redução das incertezas.

Segundo a matriz de transporte de soja desenvolvida pela ANEC (2010), a participação rodoviária no Brasil é bastante elevada (53\%), enquanto outros países de dimensões continentais como os Estados Unidos possuem uma participação maior no transporte hidroviário (60\%). O transporte teve a grandeza de 10,6\% do PIB em 2010 (ILOS, 2013), sendo um dos mais relevantes segmentos da economia brasileira. Por outro lado, a alta dependência do modal rodoviário se contrasta com um setor desorganizado e desregulamentado até recentemente. A falta de informação, baixa profissionalização e 
pouco conhecimento dos agentes promoveram a criação de um mercado de fretes altamente sazonal e informal que foi estudado por diversos pesquisadores pioneiros dos estudos de logística em commodities agrícolas no Brasil (CAIXETA-FILHO e GAMEIRO, 2001; CORREIA JUNIOR, 2001; GAMEIRO, 2003; MARTINS, 2008).

Através de ações do governo, avanço tecnológico e investimentos fortes da iniciativa privada no setor, houve na última década uma mudança drástica no perfil do empresário que trabalha com logística (NTC, 2014). Nas bibliografias advindas dos estudos da década de 90, por exemplo em Soares e Caixeta-Filho (1997), não refletem o mercado atual, que se modernizou e permitiu um novo ponto de equilíbrio econômico mais seguro e controlado, com mais empresas de transporte e menor participação de autônomos (ANTT, 2013). Em 2013, com idade média de 10,9 anos, 73\% da frota pesada havia sido emplacada na década anterior, sendo que aproximadamente $48 \%$ dos equipamentos possuía menos de 5 anos (ANTT e ANFAVEA, 2013). O setor agroindustrial correspondeu a $81 \%$ dos licenciamentos de implementos rodoviários nos últimos 10 anos (ANFIR, 2013), o que mostra claramente a importância das commodities agrícolas para o transporte e vice-e-versa.

As iniciativas políticas foram extremamente relevantes para este crescimento. Os investimentos de longo prazo em infraestrutura, as linhas de crédito a baixo custo, as transações financeiras eletrônicas e o aumento da autonomia da agência reguladora ANTT (Agência Nacional de Transportes Terrestres) permitiram maior segurança para os investidores (NTC, 2014). A coordenação vertical permite que grandes indústrias possam realizar seus investimentos e reduzir custos ao mesmo tempo. Esta teoria pode ser observada na literatura de Economia dos Custos de Transação (ECT) e como descrevem Zylbersztajn e Nogueira (2002), os arranjos contratuais podem ser copiados e difundidos de modo simétrico e contínuo entre agentes do mesmo sistema.

Naturalmente, a decisão de investimento não é algo simples e necessita de ferramentas adequadas para a previsão dos resultados. Devido à complexidade em se definir um modelo que retorne uma solução adequada e de preferência ótima, a análise multicritério pode auxiliar a tornar decisões subjetivas em objetivas, devido ao uso de critérios baseados em curvas de valor. $\mathrm{O}$ uso de análise multicritério ou MCDA (Multiple Criterial Decision Analisys) é estudado há mais de 20 anos no Brasil no segmento de logística (PRADO, 2011) e sempre foi muito focado na seleção de 
fornecedores. Sua utilização também é muito difundida para apoiar modelos de programação linear como a localização de fábricas e armazéns, modelos de otimização em geral e até em decisões de políticas públicas (MONTIBELLER e YOSHIZAKI, 2011; PADOVANI et al., 2008; FRANCO e MONTIBELLER, 2011; ROY, 2010)

Entre as diversas complexidades para se estabelecer um processo decisório, Keeney (1982) destaca que múltiplos objetivos, intangibilidade, vários tomadores de decisão, trade-offs, horizontes de longo prazo, riscos e incertezas tornam o ambiente relativamente difícil para se tomar decisões com clareza. Por causa disso, a abordagem teórica de seleção multicritério pode auxiliar os stakeholders (as pessoas afetadas pela decisão) a aprimorarem e melhorarem suas decisões. Neste contexto, Almeida (2010) define trade-off de valores como a indiferença entre duas consequências, e portanto, os stakeholders estariam igualmente satisfeitos com a escolha.

Tais elementos apresentados salientam a relevância deste tema, principalmente para embarcadores de cargas agrícolas que podem adotar estratégias mais ou menos ousadas dependendo do ambiente a que estão expostos. Como o mercado é dinâmico, possuir flexibilidade estratégica é um diferencial e para isso é importante existir inteligência analítica que permita um posicionamento assertivo. 


\subsection{Objetivos}

O objetivo principal deste trabalho é propor um modelo capaz de auxiliar a tomada de decisão sobre a definição do tipo ideal de governança para o transporte rodoviário de granéis sólidos agrícolas sob a ótica de uma Trading. Para isso será utilizado o referencial teórico a partir da Economia dos Custos de Transação, aliado à decisão multicritério (MCDA). Através desta abordagem é possível indicar se modelos de transporte verticalizados são mais interessantes do que modelos terceirizados.

As alternativas propostas para a análise consideram os seguintes arranjos de governança:

I. Integração vertical total com aquisição e operação de ativos;

II. Integração vertical parcial com aquisição de ativos e operação por terceiros;

III. Integração vertical parcial através da subcontratação de terceiros;

IV. Terceirização total, com presença de contratos de longo prazo;

V. Terceirização total sem presença de contratos (spot).

Os principais resultados esperados dizem respeito às avaliações de arranjos observadas no mercado por intermédio do uso do modelo proposto. Também espera-se com a condução dessa pesquisa:

$>$ Realizar uma revisão de literatura abordando aspectos relevantes sobre a história do transporte rodoviário e seu processo regulatório;

A Apresentar o conceito de Economia dos Custos de Transação e seus impactos na coordenação vertical;

$>$ Mapear e descrever as estruturas verticais presentes no transporte rodoviário de cargas agrícolas;

$>$ Desenvolver e aplicar um modelo multicritério em um problema real de uma grande empresa embarcadora;

$>$ Avaliar o desempenho de cada alternativa proposta em relação à aplicação realizada;

Auxiliar a tomada de decisão da empresa embarcadora em relação ao modelo de governança mais indicado para o cenário proposto. 


\subsection{Organização da dissertação}

O presente trabalho está estruturado da seguinte forma:

Capítulo 1 - Introdução: contextualização do tema, sua importância e quais os objetivos a serem alcançados durante a pesquisa.

Capítulo 2 - Revisão de literatura: exploração do arcabouço teórico sobre coordenação vertical, contexto histórico da configuração do transporte no Brasil e análise da decisão multicritério. O objetivo deste capítulo é apresentar ao leitor os principais fundamentos de contextualização do tema, principalmente na esfera institucional.

Capítulo 3 - Material e método: descrição do método escolhido para o desenvolvimento do modelo.

Capítulo 4 - Resultados: apresentação do modelo, detalhando a construção de objetivos, critérios e estratégias a serem avaliadas. Demonstração dos resultados obtidos a partir da aplicação do modelo.

Capítulo 5 - Conclusões: fechamento da discussão, trazendo uma síntese do processo para a implementação do método e recomendações para trabalhos futuros. 


\section{REVISÃO DE LITERATURA}

As complexidades encontradas durante a evolução do transporte rodoviário, a situação atual e as perspectivas futuras podem ajudar a entender como a teoria molda-se na prática encontrada nas organizações.

Entre os diversos momentos que o transporte rodoviário brasileiro viveu ficou evidente que as mudanças ocorridas na primeira década de 2000 alteraram significativamente o perfil das empresas e estruturas existentes. Tais mudanças, extremamente focadas na regulação setorial e modernização da frota, afetaram a governança e as relações existentes entre os contratantes e contratados para executar o transporte. Este capítulo irá introduzir o leitor a tais conceitos para um melhor entendimento do modelo desenvolvido.

\subsection{A história do transporte terrestre no Brasil}

Os investimentos realizados em transporte no Brasil podem ajudar a entender a atual plataforma logística e até mesmo o comportamento dos stakeholders nas decisões logísticas. Mesmo sendo um país exportador de produtos agrícolas desde o início da sua colonização, a exploração das matérias primas foi restrita à região litorânea durante muitos anos. Os primeiros grandes avanços em infraestrutura foram focados no modal ferroviário, destacando-se o Barão de Mauá como pioneiro da construção da primeira ferrovia construída no país (SANTOS, 2004). A expansão deste modal durante o século XIX acompanhou o desenvolvimento da agroindústria exportadora. Através de concessões à iniciativa privada, os investimentos eram realizados em larga escala, integrando os principais centros produtores de café e outras commodities agrícolas aos principais portos do país.

Considerada a principal modalidade de transporte do início do século $\mathrm{XX}$, as ferrovias se expandiram por todo o centro-sul do país, promovendo um acesso mais eficiente da indústria e produtos agropecuários aos centros consumidores. Controlada por capital inglês por mais de 80 anos, a São Paulo Railway foi a primeira ferrovia paulista com acesso ao porto de Santos, sendo entregue ao Estado ao fim de sua concessão (BORGES, 1990). A crise mundial de 1929 provocou ociosidade no sistema ferroviário, levando a decadência precoce das vias. Precisando modernizar o sistema 
viário, o governo lançou em 1934 o Plano Nacional de Viação, que priorizava as ferrovias como a melhor alternativa para a formação de um sistema nacional de transportes (GALVÃO, 1996).

Contudo, em 1940, as ferrovias passaram a perder importância. Galvão (1996) destaca que o sistema tornou-se inadequado ao crescimento econômico por possuir uma diversidade de bitolas, impedindo a interligação das vias e o acompanhamento dos traçados. Em 1950, com a adoção de políticas governamentais para financiar o sistema rodoviário, os outros modais de transporte ficaram estagnados até a sua privatização na década de 90 . Com a priorização do transporte rodoviário por parte do Estado, a malha férrea reduziu sua dimensão, sendo focado o seu uso em apenas alguns corredores estratégicos ligados à mineração, à siderurgia e ao agronegócio.

No modal rodoviário, Santos (2004) destaca que alguns dos atuais trajetos foram desbravados já pelos bandeirantes, sendo até o início do século XX a tração animal o principal meio de transporte. A administração das vias controladas pelo Estado dispunha de arrecadação por meio dos pedágios regulamentados por lei desde 1835 , com os moldes de cobrança se assemelhando muito com o modelo atual.

Em 1945 o Fundo Rodoviário Nacional foi criado para fortalecer as bases institucionais e financeiras a favor do transporte rodoviário, mediante financiamentos e investimentos governamentais visando à expansão, bem como as melhorias das vias (GALVÃO, 1996). No final da década de 1950 a participação das rodovias no transporte de cargas era de $38 \%$ e no final da década de 1960 chegava a $71,5 \%$.

Desde então, os investimentos públicos foram essencialmente realizados na plataforma rodoviária, sendo o jargão "integrar para não entregar” o grande desbravador das novas fronteiras. O transporte rodoviário tornou-se o principal modal para médias e longas distâncias. Isso auxiliou o processo de industrialização e a expansão da agricultura. Porém, não era ideal no aspecto econômico, em virtude da pequena capacidade de carga transportada e alto custo variável do sistema (BARAT, 1991). Caixeta-Filho e Gameiro (2001) destacam que um sistema logístico eficiente é fundamental para a competitividade das cadeias produtivas, sendo que, na situação atual as cargas perdem a competitividade em virtude dos enormes gargalos existentes pela falta de alternativas modais, condições das estradas e portos, entre outros. 
Na década de 1990, um período considerável sem investimentos devido ao baixo crescimento econômico, as vias de transporte rodoviário e ferroviário encontravam-se sucateadas (VENCOVSKY, 2012) e com uma administração incapaz de atender a demanda. Além disso, os avanços dos conceitos de logística descritos em Passarini (1999) voltaram-se para os projetos em tecnologia, aumento do nível de serviço, redução de estoques e velocidade. Surgiram então temas como a preocupação ambiental, o uso da internet como suporte tecnológico, com a intermodalidade tornando-se uma realidade para as cadeias de suprimento.

Diante disso e pela dificuldade do poder público em acompanhar a vanguarda, a decisão do Estado foi de repassar à iniciativa privada a concessão das ferrovias e rodovias (VENCOVSKY, 2012). Na primeira metade da década de 1990, com a criação do Programa Nacional de Desestatização, a RFFSA (maior gestora da malha ferroviária brasileira) e as primeiras rodovias federais foram concedidas. Os principais motivos da privatização conforme descrito por Nunes (2011) eram: a desoneração do estado; a melhoria da alocação dos recursos; o aumento da eficiência operacional; o fomento do desenvolvimento do mercado de transportes e a melhoria da qualidade dos serviços.

Durante a primeira década de 2000, o foco do Governo mudou novamente. Com a criação da Agência Nacional de Transportes Terrestres (ANTT) em 2001 (Lei n ${ }^{\text {o }}$ 10.223), a visão regulatória passou a fazer parte da pauta das suas ações. Algumas entidades como DNIT (Departamento Nacional de Infraestrutura e Transportes), responsável pela infraestrutura de estradas; a ANTAQ (Agência Nacional de Transporte Aquaviário), responsável pela navegação fluvial e de cabotagem; a própria ANTT, regulando os setores ferroviários e rodoviários, entre tantas outras organizações, descentralizaram o poder de decidir o rumo do país no setor. O poder legislativo fez grandes avanços no tocante à regulamentação. Junto com a agência reguladora (ANTT) foram criadas algumas leis e resoluções que dispuseram sobre transporte e que trouxeram grande benefício para o empresário (NTC, 2014).

Os avanços tecnológicos em documentação eletrônica descritos por Fernandez (2012) foram importantes para a melhoria da gestão de documentos e compliance contábil, fiscal e social. Outrossim, os estímulos governamentais para renovação de frota como o FINAME e a redução do IPI (Imposto sobre Produto Industrializado) também 
colaboraram para o crescimento da frota para o atendimento da demanda crescente (BNDES, 2013).

\subsubsection{Resoluções da ANTT}

A atuação da ANTT tem sido focada na revisão das regras e nas práticas do segmento, buscando aumentar a transparência e a segurança das operações. A primeira grande mudança ocorrida na segunda metade da década de 2000 foi a sanção da Lei $n^{\circ}$ 11.442/07, que dispõe sobre o transporte rodoviário de cargas e revoga a Lei $n^{\circ} 6.813$ de 1980 (ANTT, 2013).

Os principais avanços foram o reconhecimento da atividade remunerada de transporte de cargas para terceiros e a definição dos direitos e responsabilidades do transportador. Além disso, através da Resolução ${ }^{\circ} 1.737 / 06$, todo transportador passou a possuir um Registro Nacional de Transporte Rodoviário de Cargas (RNTRC), que distinguiu as figuras do Transportador Autônomo de Cargas (TAC), a Cooperativa de Transporte de Cargas (CTC) e a Empresa de Transporte de Cargas (ETC). Esta medida foi extremamente importante para incentivar a legalidade e a distinção dos agentes. De acordo com NTC (2014) a Lei $\mathrm{n}^{\circ} 11.442 / 07$ colaborou com a profissionalização das empresas de transporte de cargas. Toda a tratativa de responsabilidade, emissão de documentos e controle de pagamentos foi prevista com a finalidade de aumentar o controle sobre as operações. Além disso, reconhece a execução através da subcontratação de prepostos (mesmo que pessoa física) sem existir vínculo empregatício, penaliza transgressões e cria obrigações para os agentes que contratam e realizam o serviço.

Em 2008, a Resolução n ${ }^{\circ}$ 2.885/08 instituiu que a antecipação de pedágio (prevista pela Lei $\mathrm{n}^{\mathrm{o}} 10.209$ de 2001) deveria ser realizada por meio eletrônico. Estas antecipações também precisariam ser gerenciadas por empresas habilitadas pela ANTT. Conforme Briozo et al. (2011), na época 3 empresas foram habilitadas, sendo elas: Dbtrans, Visa do Brasil Empreendimentos Ltda. e Repom S.A. Atualmente as empresas Roadcard Soluções Integradas em Meios de Pagamento S.A e Centro de Gestão de Meios de Pagamento S.A. - CGMP também estão homologadas como emissoras de ValePedágio. Os grandes impactos destas medidas foram a desvinculação do valor do pedágio do valor do frete (Lei $\mathrm{n}^{\circ}$ 10.209/01) e uma mudança radical da postura da 
ANTT em relação aos controles eletrônicos, que passaram a fazer parte das prioridades da agência.

A instituição do pagamento eletrônico de pedágios foi um modelo para a elaboração da Resolução no 3.658/11 que trata do Pagamento Eletrônico de Fretes (PEF). Esta medida entrou em vigor devido à falta de padrão entre os meios de pagamento de frete a terceiros, regulamentando as medidas previstas pela Lei $n^{\circ} 11.442 / 07$. Além da redução da sonegação de impostos, o PEF ajudou a eliminar o uso da Carta-Frete. Esta, durante muitos anos, foi o principal meio de pagamento de frete, principalmente para o TAC e para as ETC de pequeno porte (RODOCRED, 2013).

A Carta-Frete é um contra-cheque emitido pelo embarcador ao motorista subcontratado onde consta a negociação do valor do frete. O documento é dividido basicamente em duas partes: a primeira, relativa ao adiantamento do serviço, e trata-se de um pagamento à vista para suprir parte dos custos da viagem; a segunda é a quitação, onde o transportador recebe o saldo do pagamento mediante a apresentação da comprovação da descarga. Este modelo foi altamente utilizado pelas empresas de transporte na subcontratação de terceiros, pois ele servia como capital de giro, sendo de fácil controle. A Carta-Frete era descontada essencialmente em postos de combustível e poderia ser trocada condicionada ao abastecimento do veículo, sendo o preço do diesel frequentemente cobrado com ágio financeiro. Para ter validade, muitas vezes a transportadora dona da Carta-Frete tinha que possuir uma negociação, limite de crédito ou credenciamento com a rede de postos onde era feita a troca. Além disso, nesta negociação havia a incidência de juros, pois o pagamento da transportadora era realizado em um prazo estendido, enquanto o pagamento ao terceiro era feito à vista pelo posto de combustível (RODOCRED, 2013).

Esta operação foi caracterizada pelo governo como uma prática de agiotagem. Além disso, a total informalidade nas transações impedia que os impostos e encargos da subcontratação fossem recolhidos (IR, INSS, Sest-Senat, entre outros), o que era considerado ineficiente na visão do Estado. Outros meios de pagamento como o dinheiro e cheque também eram utilizados, porém todos possuíam a mesma característica de falta de controle e alto custo social. Entre outros benefícios, a nova Resolução permitiria a correta identificação dos agentes, das operações, obrigações e 
responsabilidades financeiras e também previa penalidades ao descumprimento da lei (ANTT, 2013).

A Resolução $\mathrm{n}^{\mathrm{o}}$ 3.658/11 utilizou do processo de pagamento eletrônico através de empresas homologadas para ampliar os registros das transações. Para isso foi criado um Código Identificador de Operação de Transporte (CIOT). Este código registra todas as transações ocorridas entre contratantes (ETC e embarcadores) e contratados (TAC/equiparado - equiparam-se ao TAC as ETC com menos de três veículos e as CTC). Junto com a emissão do CIOT, em cada viagem também é emitido um Contrato de Transporte, que estabelece as condições comerciais para a prestação do serviço. Entre outros itens, são determinados no contrato as figuras do contratante, contratado, subcontratado, consignatário e proprietário da carga, além do acordo comercial realizado. É possível utilizar a mesma prática de adiantamento e quitação da CartaFrete, porém de maneira controlada. Por fim, o pagamento só pode ser realizado através de depósito em conta bancária ou através do uso de empresas homologadas pela ANTT. Estas empresas são obrigadas a emitir o CIOT mesmo quando o pagamento for realizado via depósito na conta do contratado (ANTT, 2013). Em 2011, quando a Resolução entrou em vigor, apenas as empresas que já operavam o Vale-Pedágio se homologaram (Repom S/A, Roadcard Soluções Integradas em meios de pagamento S/A, GPS Logística e Gerenciamento de Riscos S/A e Dbtrans S/A). Em 2013, a ANTT já homologara 20 empresas para prestar este serviço, sendo elas essencialmente instituições financeiras, gestoras de abastecimento, de risco e de benefícios (ANTT, 2013).

$\mathrm{O}$ uso do PEF trouxe diversas consequências positivas ao mercado, como o maior controle financeiro, profissionalização das empresas e até o recadastramento no RNTRC. O fato desta Resolução permitir a fiscalização por meio de auditoria e o alto valor das penalidades (chegando até a suspensão do registro) também colaborou com a adoção da ferramenta (RODOCRED, 2013).

Em paralelo ao uso do PEF e em sinergia com o SPED fiscal, Fernandez (2012) cita o projeto do Conhecimento de Transporte eletrônico (CT-e). O mesmo teve início em 2007 após a implantação da Nota Fiscal eletrônica (NF-e), sendo a cláusula primeira do Ajuste SINIEF 09 que determinou quais documentos em papel seriam substituídos, bem 
como a definição do CT-e. O Conhecimento de Transporte é o documento utilizado para a circulação intermunicipal de mercadorias, recolhimentos de impostos e cobrança do frete e por isso sempre deve acompanhar a Nota Fiscal do produto. O processo do SPED fiscal do governo deve ser aplicado a todos os modais de transportes. Através de um processo longo com as Secretarias de Fazenda, o primeiro Estado a receber a implantação do CT-e obrigatório foi o Mato Grosso em 2011. Em 1º de Agosto de 2013, após muitas prorrogações, a obrigatoriedade passou a ser nacional para toda e qualquer Empresa de Transporte de Cargas (ETC).

Em $1^{\circ}$ de janeiro de 2014, um novo documento passou a ser obrigatório nas operações de transporte. O MDF-e (Manifesto Eletrônico de Documentos Fiscais), por meio dos ajustes SINIEF n ${ }^{\circ} 10$ e 24, deve ser emitido no início das operações de carga fracionada com o objetivo de, eletronicamente, fiscalizar o trânsito das mercadorias com maior eficiência. Segundo a NTC (2014), o MDF-e é um predecessor do programa Brasil ID, onde cargas e veículos passarão a ser fiscalizados por meio de tecnologia RFID, o que eliminaria completamente a necessidade de documentos impressos e daria agilidade nas operações de carga e descarga, bem como na fiscalização do transporte de mercadorias. A fiscalização dos transportes ajuda o governo a controlar melhor o perfil da economia brasileira. Por isso, a EPL irá criar o Observatório Nacional de Transporte e Logística, que terá a finalidade de oferecer subsídios aos que planejam investir na infraestrutura brasileira no segmento de transporte (NTC, 2014).

A preocupação do poder público em manter o controle sobre a arrecadação promoveu uma profissionalização do setor. A alta participação de autônomos no transporte pesado no início da década de 2000, apresentada por Caixeta-Filho (2001), passou a ser de apenas de 32\% em 2013 (ANTT, 2013). Enquanto a idade média do TAC em 2013 superava 17 anos, a idade da frota das empresas (ETC) era de somente 7 anos. A capacidade de transporte por veículo de carga, que era de 26 toneladas de peso líquido na década de 1990, passou a ser de 50 toneladas na década de 2010 (ANFIR, 2013). Além disso, o implemento de transporte do tipo graneleiro (normalmente feito de madeira) está sendo substituído gradualmente por implementos basculantes e de alumínio, que garantem maior performance de carga e descarga e menor perda física de mercadorias. $\mathrm{O}$ empresário investiu pois, além da alta demanda, enxergou um ambiente seguro institucionalmente para exercer a sua atividade no longo prazo. 
Em 2012, o transporte rodoviário sofreu uma nova mudança de direção. A Lei $n^{\circ}$ 12.619, mais conhecida como 'lei do motorista', entra em vigor, atendendo diversas medidas solicitadas desde o PL n 2.660 de 1996. Basicamente, a lei limita o tempo de direção ao máximo de 10 horas por dia e cria intervalos de descanso para o motorista. Também cria direitos e deveres para o profissional motorista CLT e altera o Código de Trânsito Brasileiro. Com o objetivo de tornar a profissão e as estradas mais seguras, a Lei impede que os caminhoneiros trafeguem por mais de 4 horas sem descanso de 30 minutos e obriga um descanso mínimo de 11 horas por dia entre jornadas de trabalho, além de um descanso ininterrupto de 36 horas por semana.

O transporte rodoviário, como o principal modal utilizado no Brasil, foi um laboratório para o governo aplicar regulamentações. Apesar das dificuldades encontradas, pode-se considerar que o ambiente do transporte rodoviário está mais transparente, seguro e profissional, sendo um exemplo para os outros modais de transporte.

\subsubsection{Estímulos governamentais}

O papel do governo, que foi fundamental para a regulamentação, também foi importante para os investidores. Em um ambiente mais seguro, a disponibilidade de capital a custos baixos foi capaz de aumentar a capacidade de transporte e atender a demanda da agroindústria. Além das ações federais como o Programa de Aceleração do Crescimento (PAC I e PAC II), o Plano Nacional de Logística e Transportes (PNLT) direcionou o empresariado para os investimentos em logística no Brasil (PERRUPATO, 2012). Para possibilitar o crescimento, destacam-se também as linhas de crédito para aquisição de equipamentos (BNDES, 2013).

O principal produto obtido para a compra e renovação de frota foi a linha de crédito FINAME, do Banco Nacional do Desenvolvimento (BNDES). Com ela, os pequenos empresários e caminhoneiros autônomos poderiam ter acesso a um crédito com juros baixos (por volta de 2 a 4,5\% ao ano), com financiamento de até $100 \%$ do valor do caminhão e prazo de pagamento de 5 anos. Entretanto, para isso era essencial que a empresa estivesse habilitada na ANTT, com o RNTRC ativo e que tivesse renda comprovada. Este programa, mais destinado ao TAC ou equiparado, foi conhecido como pró-caminhoneiro (BNDES, 2013). 
A linha FINAME também foi acessível às empresas jurídicas e colaborou muito para o crescimento da frota pesada de caminhões. Além dos juros baixos, com a crise internacional de 2008, o governo zerou a alíquota de IPI para caminhões com o objetivo de manter o mercado de vendas aquecido (VALOR, 2008) A renovação da frota não é apenas uma questão econômica mas atualmente também é uma preocupação ambiental como descrevem Bartholomeu et al. (2008). De acordo com o estudo, veículos mais novos consomem menos combustível e emitem uma quantidade inferior de gases tóxicos. Além disso, a partir de 2012, os novos caminhões deveriam ser fabricados obrigatoriamente com uma nova tecnologia conhecida como Euro 5, menos poluente e com o uso de um combustível com menor concentração de enxofre, o Diesel S10.

Além dos estímulos ao transporte, Rocha et al. (2012) destacam que a armazenagem pode ser um fator decisório para a comercialização e ganhos de receita para os produtores de grãos. Além disso, armazenar as safras permite que exista demanda de transporte durante o ano inteiro, reduzindo os custos logísticos de ociosidade de ativos. Por isso, o Governo também subsidiou a construção de armazéns através do FINAME, o que foi positivo para todo o cenário logístico.

Além das linhas de crédito, os programas de governo prometiam investimentos significativos na integração multimodal. O PNLT, sendo o guia dos investimentos no setor, pretende em um horizonte de 20 anos alterar a matriz de transporte, tal proposta encontra-se destacada na Figura 01 (PERRUPAT0, 2012).

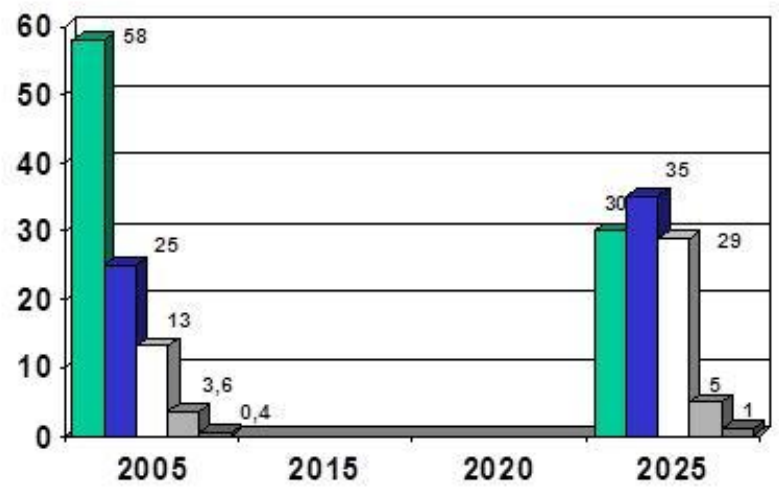

Figura 01 - Matriz de Transportes proposta pelo PNLT (PERRUPATO, 2012, slide 43). O PNLT, conforme Perrupato (2012), tem como foco atuar em vetores socioeconômicos, reduzindo as desigualdades no território nacional através da redução 
dos custos de transporte. Os principais projetos estão descritos na Figura 02, sendo o destaque para a construção da integração Norte-Sul e Leste-Oeste, onde as novas ferrovias estarão conectadas. Os investimentos em ferrovias passaram a ser prioridade entre os projetos apresentados. A expansão da malha torna-se necessária, uma vez que a malha atual não atende o desenvolvimento econômico e o avanço da fronteira agrícola.

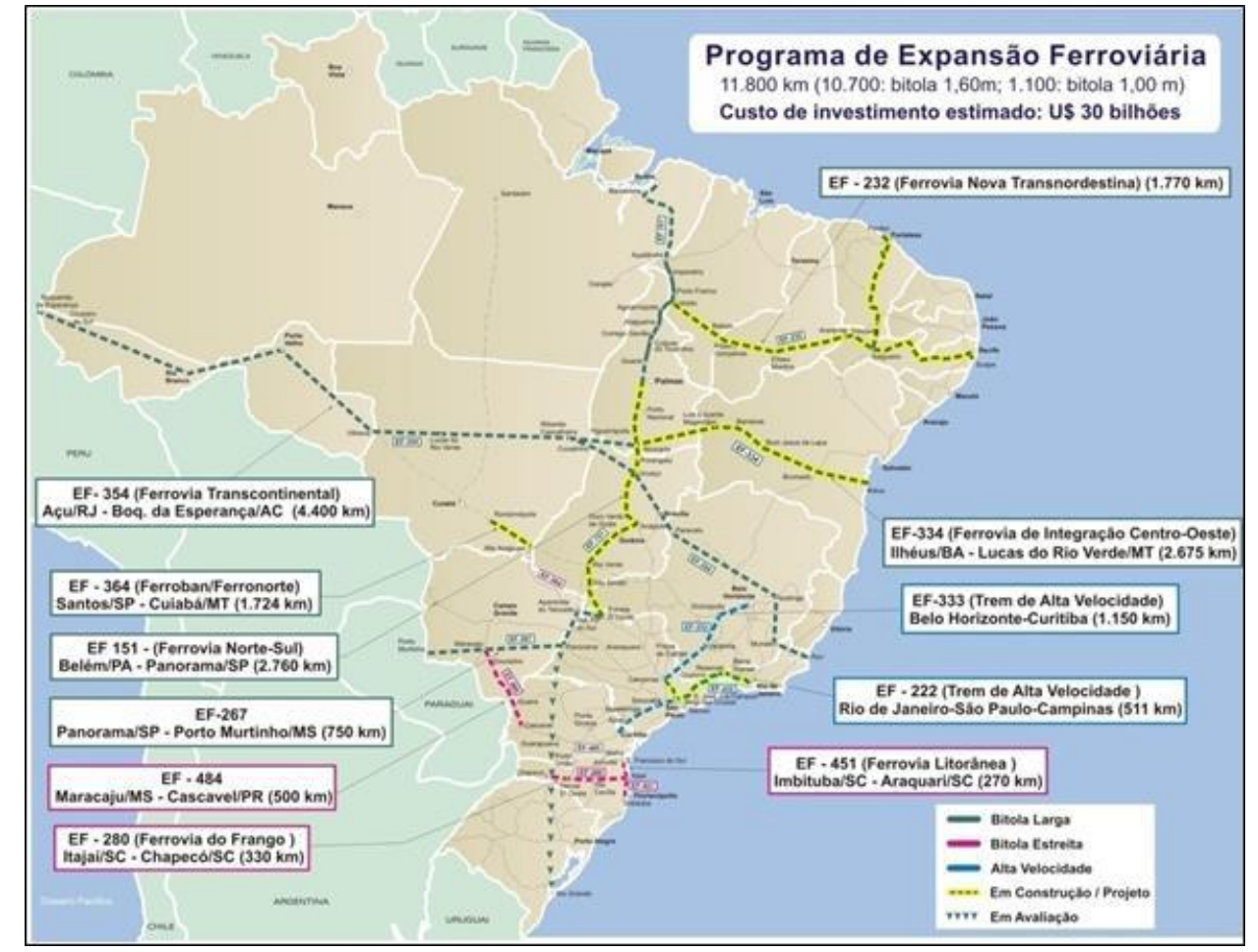

Figura 02 - Programa de expansão ferroviária (PERRUPATO, 2012, slide 53).

Pela nova plataforma multimodal existe a expectativa de que a competitividade do produto brasileiro não fique unicamente nas estradas. A interligação multimodal é prioridade da Empresa de Planejamento e Logística (EPL), que será a responsável por gerenciar os programas de governo no tocante a investimentos logísticos (PERRUPATO, 2012). Por isso, aborda-se a seguir os aspectos institucionais e a caracterização do modal rodoviário, utilizando-se a ótica de Economia dos Custos de Transação.

\subsection{A Economia dos Custos de Transação}

O referencial teórico de ECT (Economia dos Custos de Transação) pode ser observado nos estudos de Coase (1937) e Williamson (1985). Esta linha de pesquisa sugere que as características de uma transação seriam estabelecidas por um determinado período e 
espaço geográfico e que os seus custos de transação seriam determinados pela incerteza, frequência e grau de especificidade dos ativos envolvidos nas operações. Também abordado a partir da Nova Economia Institucional, os custos de transação ganharam muita importância por enxergarem a cadeia produtiva como um todo, sendo as relações comerciais e seus contratos o principal foco dos estudos. O princípio básico descrito por Zylbersztajn (1996) é de que existem custos na utilização do sistema de preços, sendo estes custos conhecidos como custos de transação.

O estudo da coordenação vertical pode ser realizado através da análise das dimensões das transações, que são caracterizadas por Williamson (1989) como a especificidade dos ativos, incerteza e frequência. Assume-se, entretanto, que alguns pressupostos comportamentais definem as formas organizacionais mais eficientes: a racionalidade limitada; o oportunismo; as dimensões da transação.

A racionalidade limitada, conforme exposto por Rodrigues (2006), é a incapacidade dos agentes fazerem previsões em uma transação, o que pode trazer risco na tomada da decisão. Bazerman e Moore (2010) associam a racionalidade limitada ao fato de o ser humano possuir heurísticas no processo de decisão associadas a habilidades adquiridas para simplificar situações complexas; entretanto, os stakeholders podem ignorar informações potencialmente relevantes por serem estranhas ou excessivas. Azevedo (2000) comenta que enquanto a racionalidade limitada é uma característica do agente, a incerteza refere-se ao ambiente. Ao transmitir este comportamento aos contratos, podese assumir que quanto maiores forem as salvaguardas, maiores serão os custos ex-ante das transações, entretanto os custos ex-post podem reduzir.

Araújo e Martins (2003) destacam que as relações comerciais podem ser incompletas, e mesmo havendo ativos específicos na transação, os agentes podem adotar comportamentos oportunísticos. Por isso, as estruturas de governança auxiliam na sobrevivência dos contratos de longo prazo (ZYLBERSZTAJN, 1995). O oportunismo, pela ótica de Neves (2001), se do tipo ex-ante, ocorre principalmente na negociação de contratos antecipados; se do tipo ex-post, ele ocorre durante a execução do contrato. Stern et al. (1996) colocam que a ECT é importante para ajudar na decisão de como as companhias podem trabalhar na cadeia e no mix de integração vertical e por isso foi uma referência que influenciou muitos trabalhos no segmento de cadeia de suprimentos. 
Rodrigues (2006) e Ribeiro (1997) realizaram estudos relacionados à coordenação vertical nas operações de colheita de cana-de-açúcar e transporte de madeira, respectivamente. Os trabalhos utilizam-se da análise das dimensões da transação por serem facilmente mensuradas através dos contratos. Farina et al. (1997) propõem que estas dimensões sejam classificadas através dos atributos de especificidade dos ativos envolvidos, frequência das transações e incerteza.

Williamson (1991) propôs um modelo básico para medição dos custos de transação, considerando três funções de custo de governança: M (mercado), X (formas híbridas) e $\mathrm{H}$ (forma hierárquica). Os dois parâmetros determinados são a especificidade de ativos (k) e os parâmetros de deslocamento $(\beta)$, que serão baseados no trade-off entre as formas híbridas e hierárquicas. A Figura 03 representa a relação entre as funções, principalmente no tocante à especificidade dos ativos, podendo-se interpretar que quanto maior a especificidade do ativo, a forma hierárquica apresenta o menor custo de transação, sendo que em situações com menor especificidade uma estrutura baseada em mercado apresenta o menor custo entre as três funções.

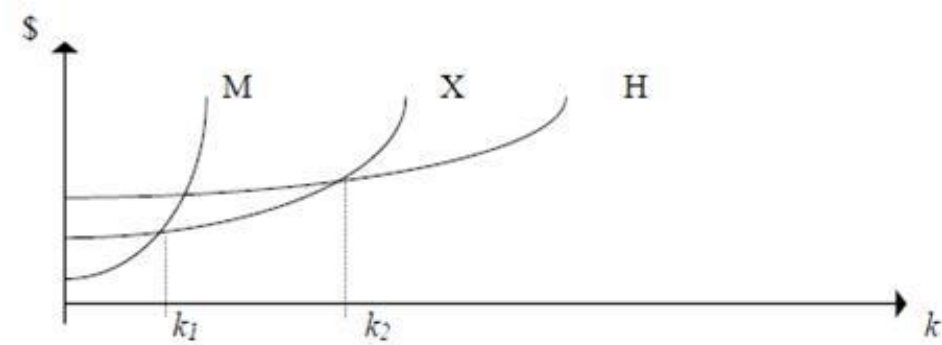

Figura 03 - Custos de governança em função da especificidade dos ativos (WILLIAMSON, 1991, p. 108).

A especificidade dos ativos, segundo Farina et al. (1997), trata do uso de ativos específicos que não podem ser reutilizados sem a perda do seu valor, sendo a transação em questão dependente de tal especificidade. Usualmente, a especificidade dos ativos pode ser classificada como: Locacional; Ativos humanos; Física; Temporal; de Ativos Dedicados. A especificidade dos ativos de transporte de granéis sólidos agrícolas é baixa e conforme descrito por Caixeta-Filho e Gameiro (2001), as exigências do tipo de veículo não são restrições para o transporte de grãos. 
A frequência de transações, quando elevada, pode reduzir o custo fixo médio da transação; e quando muito elevada, pode reduzir as perdas para as duas partes, diminuindo o comportamento oportunístico (AZEVEDO, 2000). As transações recorrentes também podem estabelecer confiança, reduzindo os custos de transação e tornando o resultado mais previsível.

A incerteza normalmente é associada a falta de conhecimento e informação incompleta ou assimétrica (FARINA et al., 1997). No transporte de granéis sólidos agrícolas, a sazonalidade observada nos fretes é uma característica do segmento e pode ser facilmente influenciada de acordo com o tipo de governança executada pelo mercado. A incerteza durante o processo regulatório do transporte rodoviário, por exemplo, motivou uma elevada alta nos fretes no Brasil devido ao oportunismo dos agentes. Por outro lado, após o processo de adaptação, o ambiente institucional forte é um importante mecanismo redutor de destas incertezas. Williamson (1991) demonstra graficamente (vide Figura 04) os efeitos da incerteza sobre as estruturas de governança. É importante notar que em mercados com elevada incerteza (alta frequência de distúrbios), as formas híbridas são inviáveis, o que promove maior custo de transação entre os agentes neste ambiente.

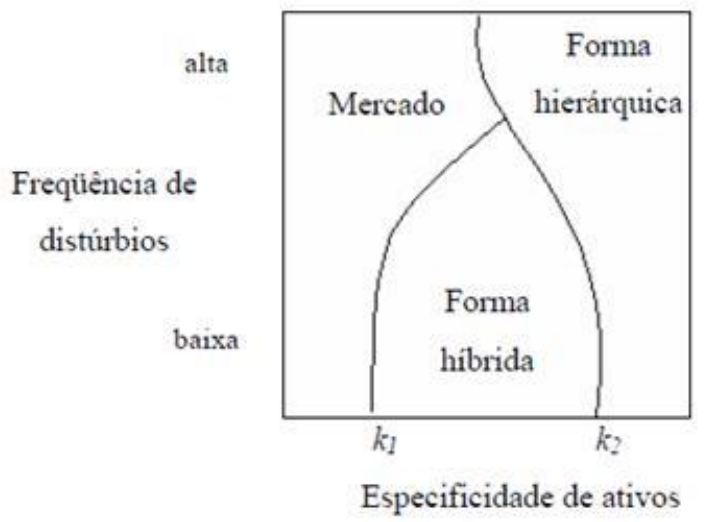

Figura 04 - Forma organizacional em resposta a mudanças na frequência dos distúrbios (WILLIAMSON, 1991, p.117).

O ambiente institucional, por sua vez, é um fator decisivo para redução dos custos de transação. Para North (1992), as mudanças formais e informais podem limitar as transações; porém, a influência de suas alterações pode gerar oportunidades e definir qual o tipo de organização que será criada. O processo regulatório nos transportes no 
Brasil desde o início da década de 2000 colaborou muito com a evolução tecnológica, infraestrutural e na tomada de decisões políticas e econômicas. Os estudos com enfoque em ECT devem utilizar o ambiente institucional como unidade de análise, pois as mudanças podem alterar o desenho dos arranjos mais eficientes (ZYLBERSZTAJN, 1995).

\subsection{Caracterização do sistema de transporte rodoviário pela ótica de ECT}

O transporte rodoviário de granéis sólidos agrícolas é aquele realizado por caminhões e envolve baixa especificidade dos ativos, além de ser altamente pulverizado e flexível. Os agentes envolvidos neste segmento são as transportadoras que executam o transporte e os embarcadores que contratam o transporte de suas mercadorias. A estrutura de governança é geralmente regida via mercado, principalmente devido à alta incerteza e à baixa especificidade do ativo. Entretanto, a presença de formas híbridas vem fazendo parte das estratégias das organizações.

O poder de barganha descrito por Barros e Ramos (2005) mostra que verticalizar-se em apenas algumas atividades do transportador pode reduzir os custos de transação. Machado (2004) destaca que arranjos produtivos locais, onde a reputação é um fator decisivo, permitem que empresas se verticalizem sem acrescer custos de transação. Tal comportamento pode ser explicado principalmente por causa da especificidade locacional, que acaba valorizando as comunidades e trazendo riquezas e serviços para o entorno de um determinado arranjo produtivo.

No caso do transporte, caracterizam-se como serviços auxiliares aqueles que envolvem os fornecedores de insumos (combustível, pneus, concessionários), bem como os serviços de apoio (manutenção, hospedagem, alimentação), uma vez que a maior parte destes frequentemente é terceirizada pelas empresas de transporte. $\mathrm{O}$ ativo específico (caminhão) e a mão-de-obra, apesar de serem os serviços principais, muitas vezes são terceirizados através da subcontratação, principalmente quando a demanda é maior que a oferta de veículos do transportador.

Para Soares e Caixeta-Filho (1997), o mercado de fretes rodoviários, sem controle governamental, era regido pela oferta e demanda por transporte. Neste ambiente, muitos transportadores trabalhavam abaixo do custo e cediam descontos na negociação do frete em troca da negociação. Todavia, na época em que o artigo foi escrito, nichos 
específicos como granéis líquidos já possuíam um mercado mais profissional e mais organizado hierarquicamente do que o transporte de grãos.

Mason et al. (2007) utilizam a teoria de Williamson e desenham a cadeia de suprimentos como um sistema que se coordena vertical e horizontalmente. Os agentes atuam em busca da colaboração e os transportadores são a "engrenagem" para o bom funcionamento do sistema. Os transportadores que conseguem fornecer um melhor nível de serviço são os que possuem maior colaboração entre os fornecedores, vendedores e clientes. Neste segmento, possuir um ativo flexível também é essencial, pois reduz os fatores de incerteza de mercado. Por exemplo, um veículo com implemento do tipo Hopper (Figura 05) somente descarrega em moegas de alta performance, e é incapaz de utilizar-se de um frete de retorno de fertilizantes (OLIVEIRA et al., 2010), por isso trabalha no modelo carregado-vazio, com $50 \%$ de produtividade. Já um implemento do tipo basculante (Figura 06) conseguiria ter maior produtividade por executar o transporte com maior percentual de utilização, executando o transporte de cargas tanto no trajeto de ida como de volta.

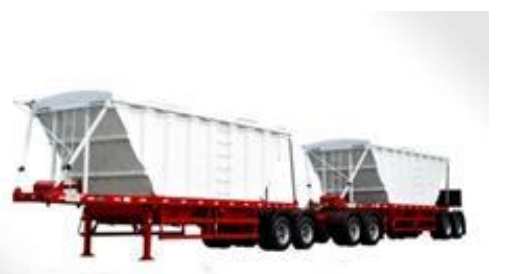

Figura 05 - Veículo autodescarregável do tipo Hopper (PASTRE, 2013).

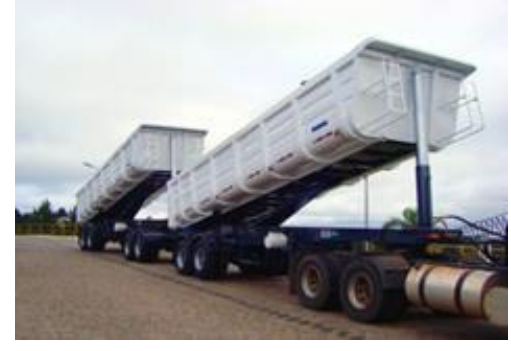

Figura 06 - Veículo autodescarregável do tipo Basculante (PASTRE, 2013).

Aspectos bastante evidentes da especificidade dos ativos promoveram um mercado altamente sazonal. Martins et al. (2004) associam a sazonalidade de movimentação ao longo do ano, o uso do frete de retorno e o tipo de ativo como fatores que afetam o 
custo de transação. A terceirização no transporte, segundo os autores, é uma característica do segmento agroindustrial; entretanto, em momentos de maior demanda, esse fator leva ao oportunismo, principalmente pela ausência de contratos formais.

No setor florestal (RIBEIRO, 1997), nas operações de corte, colheita e transporte de cana-de-açúcar (RODRIGUES, 2006) e transporte refrigerado de carnes (AZZAM, 1997), observa-se maior integração dos agentes via contratos. A especificidade do ativo e o capital intensivo utilizado no transporte são fatores decisivos para a escolha de um arranjo hierárquico. Em mercados em desenvolvimento, conforme estudo de Ruijs et al. (2004), o ambiente é fator decisivo para determinação dos custos de transação. No caso desse estudo, a própria infraestrutura rodoviária para transporte durante alguns períodos do ano promovia aumento de custos.

No Brasil, o modelo de transporte terceirizado é bastante difundido. Transportar carga com veículo próprio era uma modalidade pouco utilizada, principalmente em função da baixa regulamentação da mão-de-obra antes da Lei n $12.619 / 12$. Entretanto, a estrutura de captação dos transportadores pequenos ou autônomos não é sempre utilizada pelos embarcadores. Por isso, o alicerce da cadeia rodoviária se inicia com o prestador do transporte propriamente dito. Este contratado pode ser um autônomo ou frotista, pessoas física e jurídica, que possuem o ativo específico (caminhão). Se o embarcador possuir estrutura de captação própria, a contratação é realizada de maneira direta; porém, é comum estar presente a figura do intermediário, um agente de cargas ou transportador misto (NUNES, 2012).

O agente de cargas é uma pessoa jurídica que essencialmente subcontrata motoristas terceiros (autônomos ou frotistas). Ele pode possuir uma frota própria para o cumprimento de suas obrigações caso o mercado de terceiros não esteja suprindo suas necessidades (neste caso ele seria um transportador misto). A agência de cargas costuma também manter a fidelidade com alguns motoristas, denominando-os de "agregados". Neste caso pode haver um contrato formal de prestação de serviço entre tais empresas e frotistas/autônomos; mas, muitas vezes o preço do frete é regido via mercado. O principal cliente do agente de cargas é o embarcador que não possui estrutura de captação de motoristas e que possui a demanda pelo transporte (NUNES, 2012). 
Para o agente de cargas existe uma distinção entre o frete motorista/carreteiro (despesa paga ao subcontratado) e um frete empresa (receita paga pelo embarcador). Para executar o serviço são cobradas margens sobre o custo de frete motorista que podem girar em torno de 10 a $13 \%$ nas rotas de açúcar no Estado de São Paulo, segundo o Sifreca (2013). O agente de cargas é um dos principais termômetros dos custos de transação no transporte, pois ele é o principal intermediário da cadeia.

De acordo com levantamento prévio desta pesquisa, os embarcadores apontaram que ao negociar um frete empresa (ex-ante), a agência assume o risco de que o frete motorista que será praticado pode sofrer uma oscilação dentro da margem de lucro. Este risco é adicionado ao custo, bem como os custos financeiros (prazo de pagamento), seguro, pedágio, entre outros custos administrativos. Durante a execução do transporte (expost), o frete motorista pode sofrer influência do mercado (oferta e demanda). Por oportunismo dos subcontratados, o agente que não tiver frota ou contratos formais não conseguirá executar o serviço. A principal consequência da não execução do contrato pode ser simplesmente a não recontratação do serviço ou a queda do nível de serviço.

O frete empresa de soja, que é acompanhado pelo Sifreca (Sistema de Informações de Fretes de Cargas Agrícolas), chega a oscilar mais de $20 \%$ ao longo do ano, sendo que por este motivo muitos embarcadores recorrem a contratos de transporte rodoviário com operadores logísticos durante os períodos de maior demanda (safra), negociando antecipadamente valores e volumes. Tendo em vista que custos do tipo ex-ante podem ser muito elevados, parte do volume pode ser negociado através de frete spot ou frete praticado no dia (fora do contrato). O frete motorista/carreteiro é um exemplo de negociação diária na contratação de autônomos/frotistas. Por este motivo, alguns embarcadores acabam contratando diretamente o motorista autônomo e emitem o próprio Conhecimento de Transporte, vale-pedágio, contratação do seguro, emissão do CIOT e pagamento eletrônico de frete (dados obtidos através das entrevistas).

A sazonalidade da demanda é um fator que também influencia um comportamento migratório de caminhões. A falta de movimentação durante alguns períodos do ano obriga os transportadores viajarem pelo Brasil procurando cargas. As entrevistas realizadas ao longo do desenvolvimento desta dissertação mostraram que muitos embarcadores optam por possuir estrutura de captação, pois conseguem deslocar seus frotistas, garantindo flexibilidade e movimentação ao longo dos 12 meses do ano. A 
emissão dos documentos reduz significativamente os custos de gestão do proprietário do veículo.

Possuir ativos não é comum entre os embarcadores. Entretanto, modelos mistos são observados nos Estados Unidos por Han (2008), que descreve situações em que embarcadores buscam melhorar o desempenho e nível de serviço através da aquisição de reboques, sendo transacionado apenas o serviço de transporte associado ao cavalo mecânico, este sim precificado no mercado spot.

A expectativa deste trabalho é entender como verticalizar-se na cadeia pode ser uma boa estratégia ao embarcador para reduzir a assimetria informacional e incertezas.

\subsection{Utilização de Seguros no transporte de cargas}

O seguro de transporte, além de ser uma responsabilidade legal do transportador, também é uma ferramenta para a minimização de riscos dos mais diversos da atividade. Apesar do baixo valor das commodities agrícolas, o seguro de Responsabilidade Civil do Transportador Rodoviário de Cargas (RCTR-C) é obrigatório para as transportadoras e cobre danos ao veículo, terceiros e a carga (CAIXETA-FILHO e GAMEIRO, 2002). Existem outras duas modalidades de seguro: Responsabilidade Civil Facultativo por Desaparecimento de Carga (RCF-DC), muito difundido entre os transportadores, pois é complementar ao RCTR-C e também contempla o roubo da carga; Risco Rodoviário (RR), destinado a embarcadores e que cobre o roubo de cargas, até mesmo quando constatada "força maior" e danos ambientais com impactos mais relevantes.

Heinrich (2004) faz um mapeamento dos riscos no Transporte Rodoviário de Cargas (TRC). Seus estudos foram conclusivos de que o transporte se assemelha a uma linha de produção, que precisa de gestão e profissionais capacitados e treinados. Entretanto, os maiores riscos encontram-se fora do transporte em si, no ambiente (nas estradas, locais de descanso e nas cidades). Por isso, o seguro de cargas é importante, de modo especial, para a cobertura de acidentes com danos à mercadoria transportada de natureza civil, criminal ou ambiental. Destaca-se a ferramenta de gestão de riscos como um complemento ao seguro, sendo a redução sustentável do risco o principal objetivo, por exemplo, a utilização do monitoramento das viagens até o destino através de rastreamento e apontamento de eventos durante o transporte. 
A baixa incidência de roubos de carga de granéis sólidos agrícolas torna a responsabilidade civil o principal foco das apólices de seguros. Os riscos de acidentes em estradas precárias, o uso de drogas e estimulantes pelos motoristas e as longas jornadas de trabalho aumentam o risco de acidentes. Vita (2001) destaca que as estruturas contratuais do RCTR-C e RCF-DC também são válidas na subcontratação de terceiros e autônomos, sendo por isso importante que os veículos contratados estejam regularmente habilitados e sigam as legislações em vigor, caso contrário a seguradora possui direito de regresso contra o motorista preposto, podendo acionar judicialmente o subcontratado.

\subsection{Análise de decisão multicritério}

As decisões estratégicas são um desafio frequente enfrentado pelas empresas e nem sempre os stakeholders possuem um método formal para apoiar os problemas enfrentados. Eisenhardt e Zbaracki (1992) descrevem decisões estratégicas, tais como decisões realizadas pela alta direção das empresas que, mesmo com baixa frequência, afetam a saúde e a sobrevivência da organização.

Mcnamee e Celona (2007) destacam diversos aspectos que tornam a decisão complexa, sendo a incerteza e risco os principais fatores que obrigam uma atitude do decisor. Ambos os fatores afetam os custos de transação, e a diferença é que o risco pode ser mensurado, já a incerteza não permite tal medição de valor. Além das decisões quantitativas, Eisenhardt \& Bourgeois (1988) consideram que as decisões podem ser políticas e que variam em função do ambiente encontrado nas organizações. Diversos fatores como a hegemonia do grupo, hierarquia, coalizões e similaridades demográficas afetam consideravelmente a velocidade em que as decisões são tomadas. As habilidades políticas, por sua vez, são capazes de comprometer o desempenho das empresas de acordo com a estratégia dos diretores, devendo ser utilizadas quando não for possível uma solução quantitativa.

Dentre as técnicas encontradas para apoiar as decisões, a análise multicritério possui diversas aplicações no segmento acadêmico. A nomenclatura MCDA (Multiple Criteria Decision Analysis), que significa Análise de Decisão Multicritério ou Apoio a Decisão Multicritério, é amplamente utilizada nos estudos sobre tomada de decisão. Os autores Belton e Stewart (2002) também utilizam uma classificação em três tipos de modelos de 
aplicação do MCDA: mensuração de valor, nível de referência e outranking (sobreclassificação). Será trabalhado apenas o escopo discutido na teoria de mensuração de valor por ser o objeto foco deste trabalho. Para condução do processo de modelagem, será abordada a proposta descrita por Franco e Montibeller (2010), ilustrada na Figura 07.

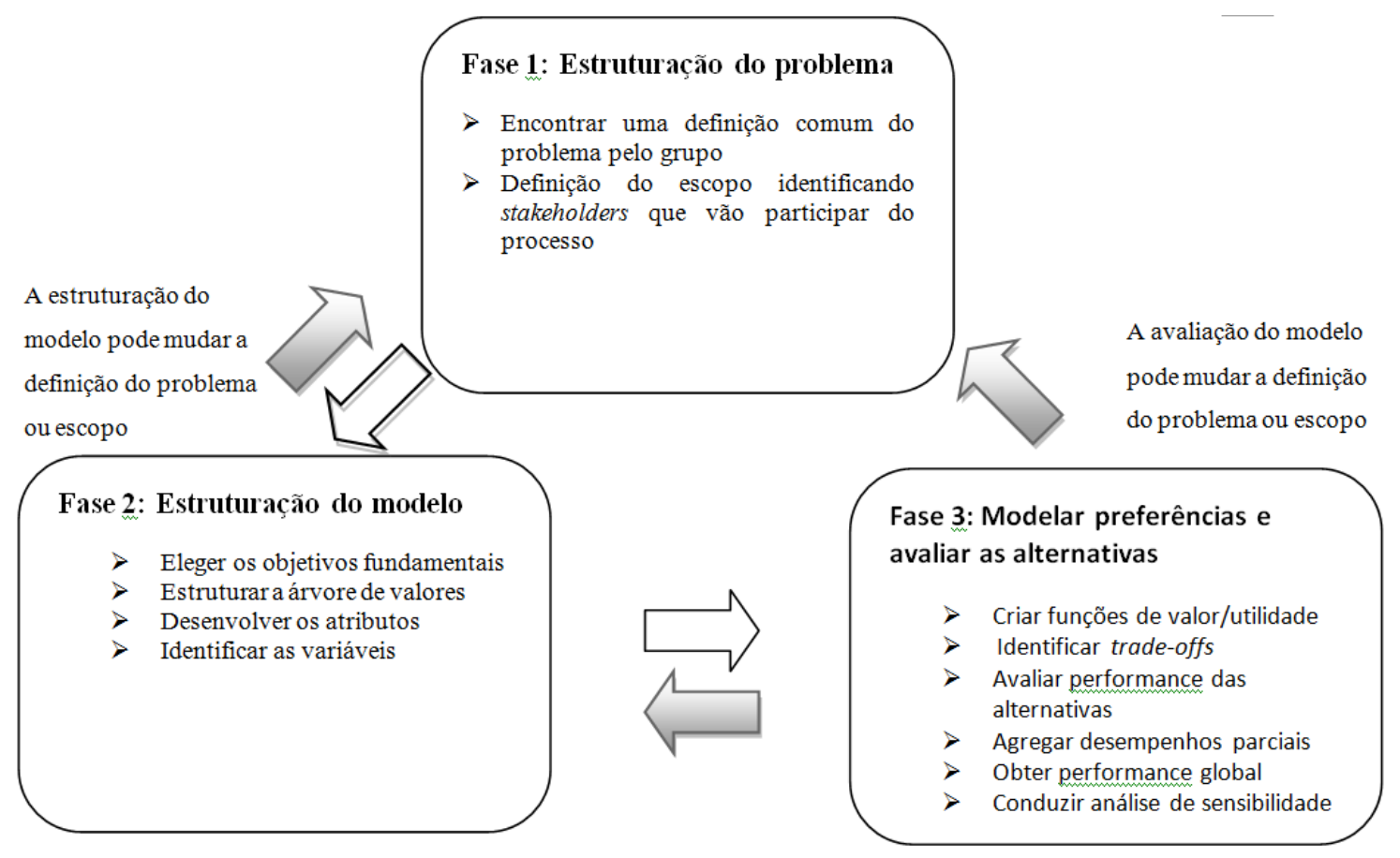

Figura 07 - Estruturação do processo de $M C D A$, adaptado e traduzido a partir de Franco e Montibeller (2010).

Esta metodologia, baseada em três fases que se interligam em torno da estruturação do problema é dividida em sub-etapas que auxiliam no processo de modelagem e está resumida a seguir:

\section{Fase 1: Estruturação do problema}

Encontrar uma definição comum do problema pelo grupo: apesar desta etapa muitas vezes parecer clara e óbvia a todos, Franco e Montibeller (2010) destacam que trata-se de um processo bastante complexo, sendo comum que problemas errados sejam resolvidos, e para evitar isso é importante revisitar esta etapa ao longo do processo. Uma das ferramentas indicadas para esta fase é a utilização de mapas cognitivos, pois eles são capazes de ilustrar ao grupo quais são os passos a serem seguidos durante a modelagem. Prado (2011) utilizou 
mapas cognitivos para capturar visões individuais de uma questão. Os mapas são conexões entre nós e setas, onde a direção da seta indica a causalidade acreditada. Sua construção é usualmente resultado de entrevistas e reuniões, e busca representar o mundo subjetivo de maneira objetiva.

Definição do escopo identificando stakeholders que vão participar do processo: Os autores desta metodologia descrevem que stakeholders são indivíduos ou grupos que têm poder para afetar a decisão ou são afetados por ela. A sua participação no processo decisório auxilia na obtenção de um melhor resultado, uma vez que possuem pontos de vista distintos e poderes para intervir e questionar o modelo. Uma ferramenta sugerida para este tipo de análise é o diagrama poder $\mathrm{x}$ interesse, utilizado quando o grupo decisor ainda não está definido. Nesta etapa é importante que o escopo esteja delimitado para evitar que durante as próximas fases o resultado se desvie do foco (FRANCO e MONTIBELLER, 2010).

\section{Fase 2: Estruturação do modelo}

$>$ Eleger os objetivos fundamentais: Os objetivos fundamentais são aqueles que devem ser resolvidos pela modelagem e por isso devem estar explícitos no mapa cognitivo e consequentemente na árvore de valores, pois estes critérios que vão nortear a decisão, sendo maximizados ou minimizados dependendo da natureza do problema. Por exemplo, em problemas de seleção de fornecedores os objetivos podem ser a minimização dos custos e a maximização dos benefícios;

D Estruturar a árvore de valores: esta estrutura é utilizada para a avaliação quantitativa do MCDA. Franco e Montibeller (2010) ressaltam que esta ferramenta é capaz de organizar os objetivos, decompô-los e consequentemente mensurá-los de maneira independente. Por isso, cada atributo deve ter o seu peso devidamente atribuído durante a construção da árvore. A multiplicação ponderada entre o peso de cada atributo com o seu respectivo peso atribuído irá posteriormente fornecer o desempenho final de uma alternativa.

$>$ Desenvolver os atributos: a definição dos atributos depende dos objetivos do problema e podem refleti-los de maneira direta ou indireta. Franco e Montibeller (2010) também salientam que eles podem ser naturais ou construídos, e consequentemente podem ser objetivos ou subjetivos. Quanto mais objetivos 
forem, a avaliação pode ser medida de maneira natural e direta. Atributos subjetivos precisam ser avaliados a partir de indicadores que possam ser comparados e avaliados da maneira o mais quantitativa possível, respeitando cinco propiedades: Não ambíguo, Fácil compreensão, Diretos, Operacionais e Entendíveis;

> Identificar as variáveis: As alternativas que serão avaliadas podem ser dadas pelo problema (já existentes) ou então construídas (novas). A geração de alternativas é utilizada quando o escopo não está totalmente fechado. Todos os stakeholders devem saber claramente distinguir as variáveis e concordarem que todas as soluções possíveis podem ser classificadas como aceitáveis, ainda que com um desempenho baixo.

\section{Fase 3: Modelar a preferência e avaliar as alternativas}

Criar Funções de valor: Belton e Stewart (2002) definem uma escala para avaliação das alternativas, onde a menor pontuação aceitável recebe valor zero e o valor máximo possível é igual a 100. Dependendo do objetivo do problema esta escala pode ser invertida, sendo o menor o mais favorável e o maior valor o menos favorável. As preferências intermediárias serão construídas a partir das preferências do grupo de tomadores de decisão, e esta curva deve representar tal comportamento (KEENEY, 1982);

$>$ Identificar trade-offs: Os pontos de indiferença são aqueles onde o stakeholder possui igual preferência e fica satisfeito por qualquer consequência da decisão (ALMEIDA, 2010). Nesta etapa estes pontos devem estar claramente explicitados para que os julgamentos posssam ocorrer de maneira individual sem influenciar o desempenho de outras avaliações;

Avaliar a performance das alternativas: Todas as alternativas devem ser avaliadas para cada um dos critérios conforme destaca Prado (2011). Esta avaliação deve ser realizada em grupo para que, em consenso, haja uma pontuação única para cada alternativa;

$>$ Agregar desempenhos parciais: O desempenho ponderado das alternativas pelos pesos correspondentes da árvore de valor irá qualificar cada alternativa em relação ao modelo proposto; 
Obter a performance global: Este resultado nada mais é do que a consolidação dos desempenhos parciais das alternativas, onde os tomadores de decisão devem analisar e validar se o resultado está coerente, adequado e satisfazendo os objetivos do grupo;

Conduzir análise de sensibilidade: Posteriormente ao resultado da aplicação inicia-se um processo de análise de sensibilidade. Esta etapa consiste em realizar variações que possam fazer sentido na opinião dos decisores. Goodwin e Wright (2004) recomendam que a verificação da robustez do problema seja realizada mediante a alteração dos parâmetros utilizados e comparando pontos de virada, ou seja, onde a decisão poderia mudar em função de desempenhos diferentes.

Além da modelagem, outros fatores devem ser levados em consideração durante o processo. Os autores De Boer e Wegen (2003) recomendam que um modelo de decisão deve ser especificado de forma clara, pois a maioria dos tomadores de decisão necessita de habilidade e treinamento para utilizar o modelo. Além disso, Keeney (1982) propõe duas abordagens para condução da modelagem: a abordagem Value Focused Thinking (VFT) que consiste na definição dos critérios, seguido dos atributos que descrevem cada critério e finalmente na criação de alternativas para o problema proposto; já a abordagem Alternative Focused Thinking é utilizada quando as alternativas são conhecidas, e a partir delas são criados os atributos e critérios. O sequenciamento das abordagens $A F T$ e $V F T$ estão apresentados na . 


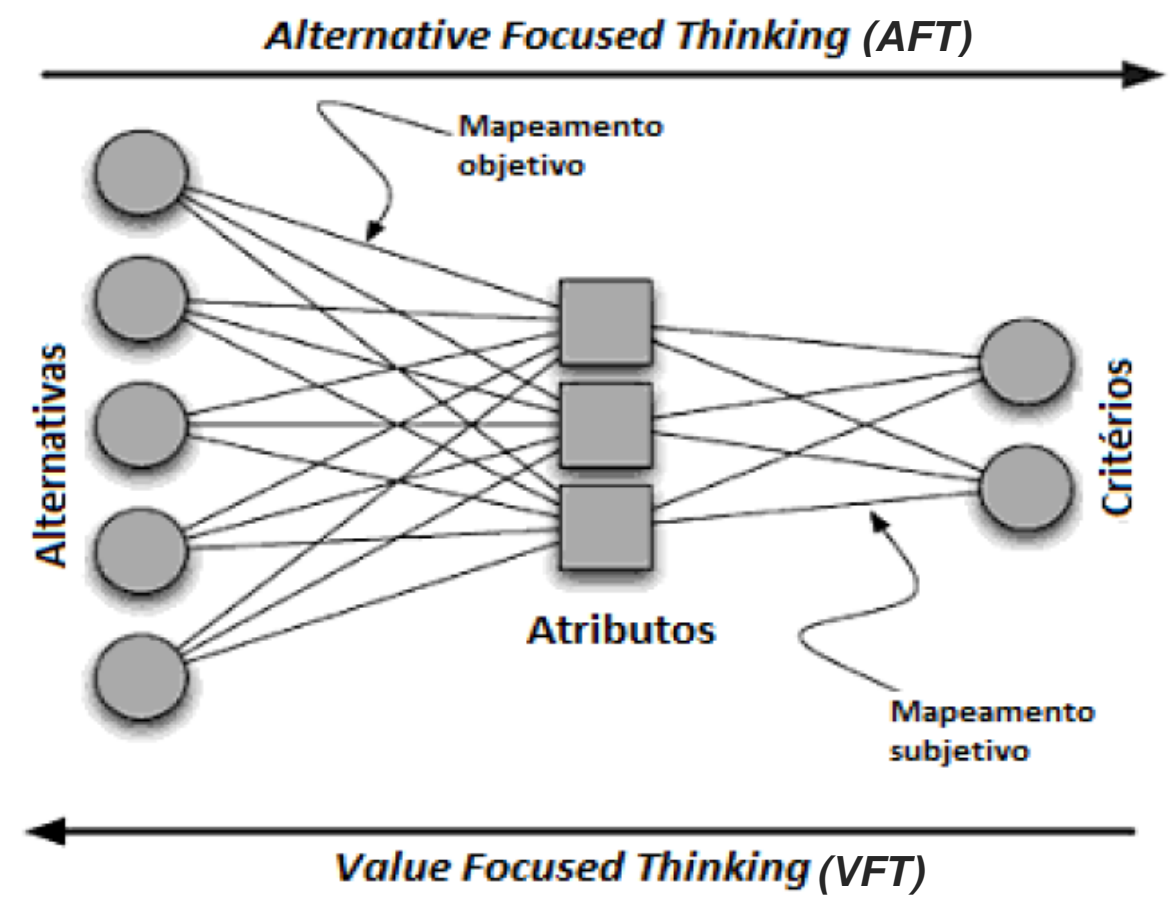

Figura 08 - Sequenciamento das abordagens AFT e VFT, adaptado a partir de Parnell et al. (2008).

Franco e Montibeller (2010) também destacam a importância do problema não estar fechado e a definição do escopo poder ser revisada ao longo do processo decisório. Para isso, a utilização de uma ferramenta tecnológica para desenhar mapas cognitivos e árvores de valores auxilia o grupo de trabalho durante todas as fases da metodologia. Entre as ferramentas computacionais disponíveis estão o Expert Choice, Make It Rational, Decision Lens e o V.I.S.A., esta última foi a escolhida para desenvolvimento deste trabalho.

Concluindo, a sequência do processo decisório influencia o resultado esperado. No ambiente corporativo, a qualidade da decisão pode ser medida pelo alinhamento do grupo em acreditar que a estratégia foi aceita por todos e que resultado quantitativo trata-se de uma combinação de atributos relacionados a custo e benefícios. Tais competências podem manter a competitividade e a sobrevivência da empresa em longo prazo, e por isso a análise multicritério pode ser uma ferramenta ágil e eficaz para atingir tais resultados. 


\section{MATERIAL E MÉTODO}

A proposta metodológica deste trabalho será conduzida pelo processo de análise multicritério (MCDA) encontrado em Franco e Montibeller (2010). Este capítulo irá auxiliar o leitor no entendimento de quais conceitos serão utilizados, em qual contexto, como também, em que o problema está inserido. As fases de aplicação do modelo estão apresentadas na Figura 09.

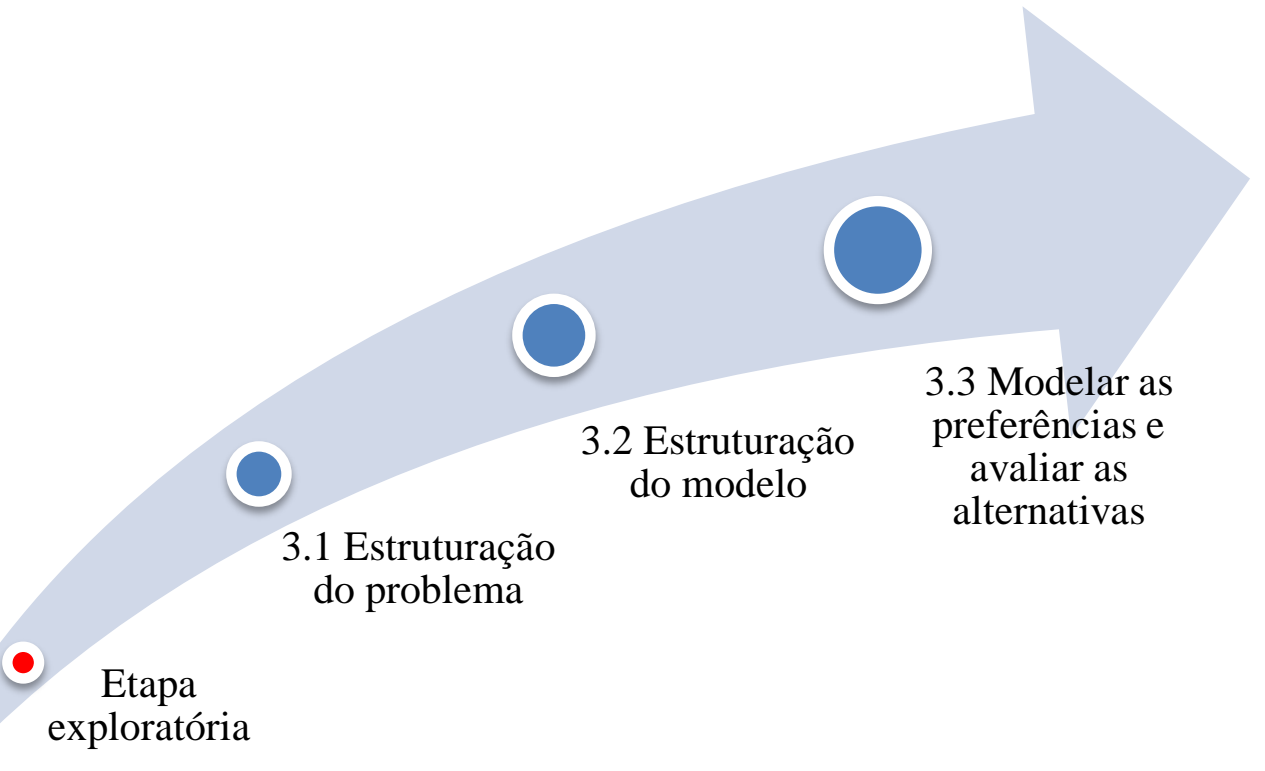

Figura 09 - Fases de desenvolvimento do trabalho.

Etapa exploratória: Antes de iniciar a aplicação do método houve uma etapa exploratória com o objetivo de mapear as principais alternativas adotadas pelas embarcadoras de cargas agrícolas. Para isso, foram realizadas entrevistas com gestores de diversas empresas durante os meses de janeiro e fevereiro de 2014. A execução destas entrevistas foi baseada em um questionário semiestruturado e a sua aplicação foi realizada por e-mail, telefone e entrevistas pessoais. O resumo do questionário e das entrevistas está apresentado no Anexo I. Ao todo, foram entrevistadas 11 pessoas, gerentes e diretores de logística de grandes embarcadoras de cargas agrícolas, que são associadas da:

- ABIOVE (Associação Brasileira das Indústrias de Óleos Vegetais e Biodiesel). Transportam granéis sólidos e representam aproximadamente 
$60 \%$ do volume da soja processada no Brasil através de 12 empresas associadas, sendo 9 delas embarcadoras e exportadoras de grãos;

- ANEC (Associação Brasileira de Exportadores de Cereais) que possui de 35 associados e que contribuem com outros 9 embarcadores rodoviários (existem associados que não realizam transporte terrestre ou já estão listados pela ABIOVE).

- ANDA (Associação Nacional para Difusão de Adubos), composta pelas principais misturadoras de fertilizantes do país, com 122 associadas.

Entre as empresas entrevistadas, uma delas (denominada neste trabalho por Trading, para preservar sua confidencialidade) mostrou-se interessada em resolver um problema alinhado com o objeto deste trabalho: a escolha de um arranjo de governança no transporte adequado para as suas atividades. Esta oportunidade permitiu que fosse realizada uma aplicação do método por intermédio de um estudo de caso.

\subsection{Estruturação do problema}

Após a definição de que o método seria aplicado em apenas uma empresa (Trading), a primeira etapa da modelagem consistiu na definição de um problema, identificação dos stakeholders e do escopo em que o problema será desenvolvido.

A abordagem utilizada para a aplicação foi a Alternative Focused Thinking (AFT), pois as alternativas a serem avaliadas já estavam presentes no ambiente e os decisores, a princípio deveriam, a princípio, eleger a estratégia que melhor atende o objetivo. Para auxiliar o suporte da aplicação foi utilizada uma modalidade denominada por Facilitative Mode, na qual o desenvolvedor do modelo participou como um facilitador atuante na compreesão do problema. As características do ambiente e necessidade de interatividade com o grupo decisor, conforme Prado (2011), são desempenhadas melhor por meio de um facilitador do que por um especialista (Expert Mode).

A Trading delimitou que o grupo de decisão seria representado por três gerentes das áreas envolvidas (Logística, Operações e Transportes), sendo que o grupo possuía em média mais de 15 anos de experiência no segmento agroindustrial e nos processos internos da empresa. Além do conhecimento específico, os entrevistados possuíam grande poder de influência sobre a decisão logística da companhia. 
O problema comum, identificado durante etapa exploratória, foi a escolha do tipo ideal de governança para o transporte rodoviário de granéis sólidos agrícolas. Esta problemática será melhor discutida durante a apresentação dos resultados.

Nessas perspectivas, foram realizados três encontros, durante os meses de março e abril de 2014. Nas reuniões de aproximadamente duas horas para a aplicação do modelo, realizadas na própria Trading, estavam disponíveis sistemas de projeção, lousas e "flipchart" para anotações. Por questões de infraestrutura existente, os três entrevistados sentaram-se ao redor de uma mesa, ao lado do facilitador (autor deste trabalho) que conduziu o processo de modelagem presencialmente. A segunda reunião também contou com a colaboração de um segundo facilitador (aluno de doutorado da Universidade de São Paulo) que auxiliou na avaliação do modelo.

Dada a complexidade de rotas, sazonalidade, dificuldade na mensuração dos custos e importância do transporte para a comercialização dos seus produtos, o escopo foi delimitado a uma rota e volume específico de grande representatividade para o transporte de commodities agrícolas. Definiu-se que o cenário ideal seria uma rota onde houvesse uma movimentação constante ao longo do ano, onde o mercado de transportadores tivesse a maior profissionalização possível, e fosse de alta importância para o negócio da empresa (Trading) que é a compra de grãos dos produtores rurais e a exportação destas mercadorias.

A rota intermodal com origem na BR-163 no Mato Grosso com transbordo na Ferronorte mostrou-se uma opção representativa e enquadrou-se nos requisitos apresentados, pois a distância de $900 \mathrm{~km}$ está próxima da média nacional de $1.000 \mathrm{~km}$ apresentada pela ANEC (2013), possui baixa sazonalidade de movimentação devido aos contratos de longo prazo com a ferrovia e está dentro do estado pioneiro da regulamentação fiscal. Na opinião do grupo esta foi a rota mais relevante para ser o objeto do estudo.

A região ao redor da BR-163 no estado do Mato Grosso é a principal produtora de grãos do Brasil e compreende municípios como Sorriso, Sinop, Lucas do Rio Verde, Nova Mutum entre outros. Sozinha concentra $15 \%$ da produção nacional de Soja e Milho (safrinha) segundo a Conab (2013). A Ferronorte (ferrovia operada pela ALL - América Latina Logística) possui transbordo de carga nas cidades de Rondonópolis, Itiquira, Alto 
Araguaia e Alto Taquari, e são operados pela própria ferrovia e por terceiros ou embarcadores que possuem armazéns com desvio ferroviário. Em 2013, a Trading carregou cerca de 7.500 veículos diferentes nesta rota, através de cerca de 4.000 contratados direta ou indiretamente. A participação de ETC não equiparado (empresas com mais de quatro veículos automotores) totalizou 55\% do volume transportado, mas a estimativa da Trading é de que a parcela total de empresas de transporte (ETC incluindo os equiparados) seja de aproximadamente $90 \%$ nesta região.

Por conta da sazonalidade e da falta de um mercado futuro de fretes, foi escolhido 2013 como ano referência para a aplicação do problema. Franco e Montibeller (2011) salientam que é importante que o problema seja de amplo conhecimento dos stakeholders. Neste ano, já haviam sido incorporadas pelo preço do frete as obrigações da Lei do Motorista (Lei $\mathrm{n}^{\circ}$ 12.619/12), que em 2012 causou uma alta generalizada nos fretes (SIFRECA, 2013). O volume executado por mês pela Trading já era conhecido e também foi possível examinar os patamares dos custos de transporte, fretes spot e dos contratos que foram realizados. Para evitar os efeitos da sazonalidade, foi considerado um volume fixo e constante mensal que na somatória representou $40 \%$ do volume transportado pela Trading ao longo do ano. O problema encontrado está estruturado na forma de um mapa cognitivo e pode ser visualizado na Figura 10. Este mapa conforme descreve Prado (2011) deve ser um resultado da estruturação do problema, retratando as etapas do processo e premissas assumidas. A elaboração do mapa ocorreu após a primeira reunião do grupo, onde o problema foi discutido e as premissas foram definidas. 


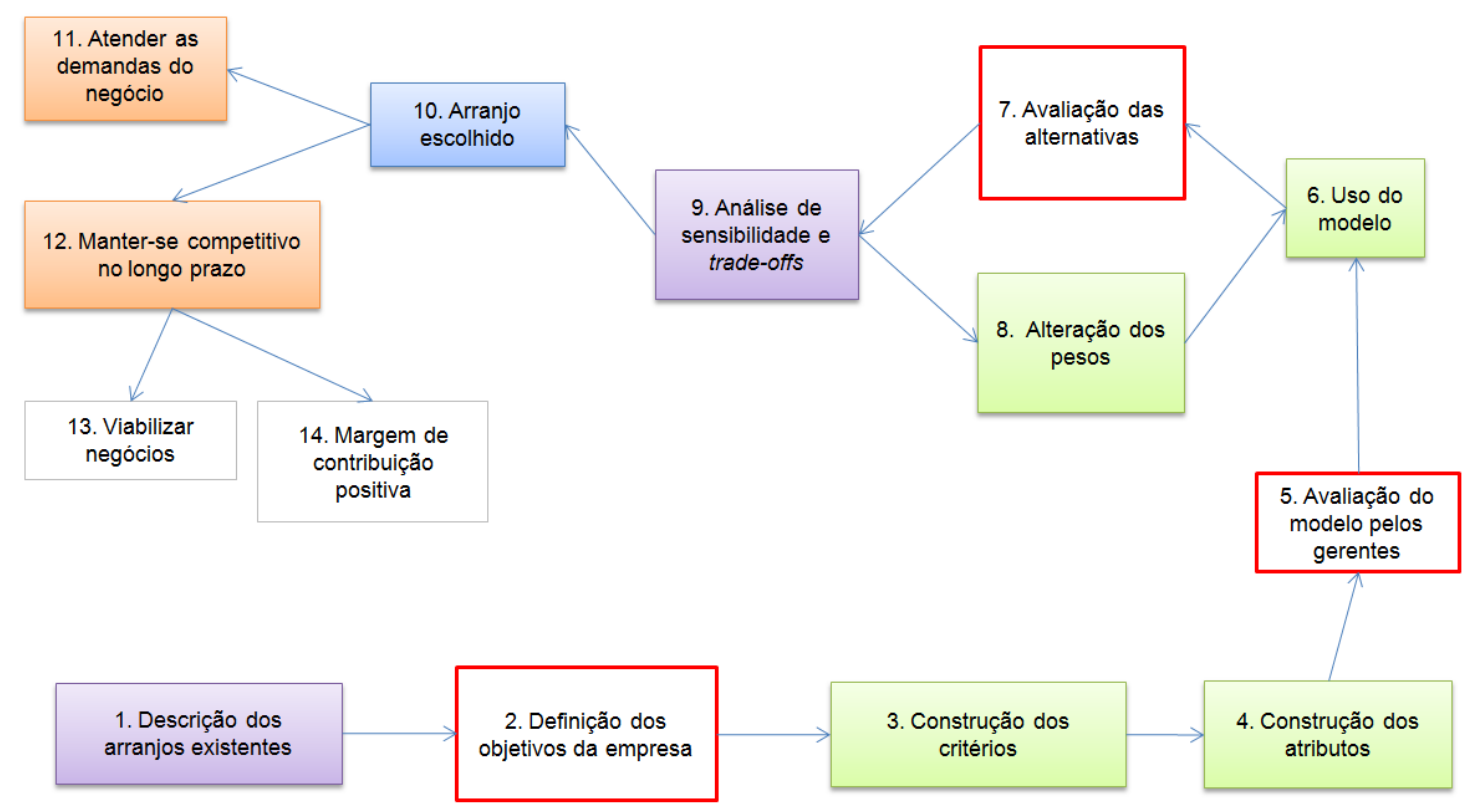

Figura 10 - Mapa cognitivo do problema proposto com base no processo MCDA.

$\mathrm{Na}$ escala visual podem-se notar diferentes etapas da modelagem que se interrelacionam ou que fizeram parte do mesmo processo. Em laranja (11 e 12) estão os objetivos do negócio: atendimento da demanda e a competitividade no longo prazo. Em branco com linha azul (13 e 14) a materialização do objetivo, que pode ser observada pela viabilização de novos negócios e a manutenção de margens positivas. O quadro em azul (10) trata da escolha do modelo de governança (output do modelo). Em lilás (1 e 9) está apresentado o comportamento das variáveis no ambiente proposto, primeiramente o comportamento dado aos cenários de custo e trade-offs atuais, e no final do processo as variáveis trabalhadas durante a análise de sensibilidade. As etapas em verde (3, 4, 6 e 8) são as interferências realizadas pelo autor/facilitador, ou seja, as etapas que foram realizadas durante as entrevistas: construção dos critérios, atributos, uso do modelo e calibração dos pesos. O resultado das aplicações descritas nos pontos 2, 5, e 7 em vermelho é o gatilho que faz o modelo funcionar, trata-se da qualificação dos objetivos, critérios e alternativas pelo grupo que irá suportar o resultado obtido.

Belton e Stewart (2002) ressaltam que durante o processo de mapeamento do problema é fundamental a avaliação dos aspectos destacados na Tabela 01. Juntos, estes conceitos devem auxiliar na construção dos objetivos fundamentais. 


\begin{tabular}{ll}
\hline Conceito & Descrição \\
\hline Relevância de valores & Os stakeholders precisam conseguir conectar o problema \\
& e seus objetivos ao referencial teórico. \\
Entendimento & Validação do entendimento dos conceitos entre os \\
usuários. & Os critérios devem ser capazes de medição pelos \\
Capacidade de & tomadores de decisão. \\
Mensuração & Diferentes critérios não devem ser mensurados pelo \\
Redundância & mesmo fator. \\
\hline Independência de & $\begin{array}{l}\text { Não deve existir interdependência para julgar o } \\
\text { Julgamento }\end{array}$ \\
Balanceamento perfeição & Os detalhes devem ser simples o suficiente para explicar \\
e concisão & o problema evitando complexidades desnecessárias. \\
Operacionalização & Baixo esforço para descrever cada critério o que facilita \\
\hline
\end{tabular}

Tabela 01 - Aspectos importantes para descrição do problema, adaptado de Belton e Stewart (2002).

\subsection{Estruturação do modelo}

A segunda etapa da modelagem proposta por Franco e Montibeller (2010) é a estruturação do modelo, que é composta por quatro fases: identificação dos objetivos fundamentais, estruturar a árvore de valores, desenvolver os atributos e identificar as variáveis.

Entre os trade-offs observados na logística do agronegócio a relação Custo x Benefício é a mais importante. Enquanto o Custo estabelece a competitividade para se originar produto (quanto menor o custo maior o poder de compra), a qualidade durante a execução do embarque determina o resultado do negócio. Assim como estas definições, ao longo da primeira reunião as anotações realizadas em um quadro de papel (flip chart) foram a principal ferramenta para estabelecer os objetivos, premissas e principais tradeoffs encontrados pelo grupo. 
A partir da definição dos objetivos fundamentais, o próximo passo foi a construção da árvore de valores. Esta estrutura deve representar de maneira clara o problema e de acordo com Franco e Montibeller (2011) a construção pode ser realizada "de baixo para cima" (bottom-up) conforme abordagem AFT ou "de cima para baixo" (top-down) na abordagem VFT. Esta propriedade fundamentou a escolha pela aplicação pela $A F T$ e por isso o modelo será detalhado a partir dos subcritérios para então chegar ao objetivo global.

Os atributos ou critérios podem ser qualitativos ou quantitativos e devem ser capazes de diferenciar características de uma determinada escolha. Muitas vezes eles podem ser conflituosos, por esta razão, Franco e Montibeller (2007) utilizam a compensação por meio de curvas de valor para quantificar e diferenciar as preferências em problemas reais. Por conta da grande quantidade de critérios e abordagens diferentes para a sua classificação, o uso de ferramentas tecnológicas auxilia o processamento da informação, dessa maneira, sendo escolhida a ferramenta V.I.S.A. (versão estudantil), por ser de fácil uso, e tendo sido utilizada por diversos estudos em $M C D A$.

Durante a etapa exploratória foram levantados diversos atributos que poderiam fazer parte dos objetivos dos tomadores de decisão. Na primeira reunião da Trading estes critérios foram apresentados para serem incorporados ou excluídos do modelo adotado. Os atributos selecionados foram profundamente desenvolvidos, e tiveram a sua descrição detalhada para ajustarem-se às necessidades da companhia. Assim como os atributos, as variáveis obtidas no levantamento primário também foram ratificadas pelo grupo nesta aplicação.

No problema enfrentado as variáveis escolhidas foram os modelos de verticalização disponíveis no mercado, sendo excluídas alternativas não existentes ou não operacionalizáveis (como somente a terceirização da mão-de-obra). As variáveis foram avaliadas individualmente, ou seja, não houve a criação de uma alternativa híbrida combinando duas estratégias de verticalização. Esta premissa foi para permitir a avaliação com independência de julgamento e para facilitar com que as demais propriedades dos critérios apresentadas na Tabela 01 fossem respeitadas. 


\subsection{Modelar as preferências e avaliar as alternativas}

Esta etapa da modelagem foi realizada em uma segunda reunião com o mesmo grupo anterior; porém, o encontro também contou com a presença de um estudante de Doutorado que auxiliou o facilitador na condução da entrevista. Entre as tarefas realizadas foram efetuadas a ponderação dos pesos, a construção das curvas de valor e a aplicação do modelo para obtenção do desempenho global.

Inicialmente foi apresentada a consolidação dos pontos levantados na primeira reunião, e o processo foi focado na construção das curvas de valor e na avaliação das alternativas. Para a ponderação dos pesos, utilizou-se uma planilha eletrônica em MS Excel com uma estrutura de árvore simplificada, onde os gestores atribuíram pesos para quantificar as preferências entre Custo e Benefício. Também foram ponderados os pesos relativos aos subcritérios nesta mesma planilha.

Para cada subcritério foram criadas curvas de valor, funções capazes de explicar as preferências do grupo sobre as compensações de cada escolha. Keeney (1982) ressalta que os julgamentos sobre as consequências não são certos ou errados, mas apenas determinam a atitude e os limites do decisor. A amplitude de determinado atributo deve variar entre o mínimo aceitável e o máximo possível, podendo variar de maneira linear ou não linear.

Após a construção da árvore, com os pesos dos critérios atribuídos e funções de valor construídas, foi possível iniciar a avaliação das alternativas. Neste processo são qualificados os desempenhos de cada alternativa para cada subcritério, de modo que a composição dos desempenhos seja capaz de classificar a que mais atingiu os objetivos da empresa.

A consolidação dos desempenhos parciais foi realizada posteriormente com o auxílio do software V.I.S.A.. Com esta plataforma foi possível fazer algumas análises de grande importância para a decisão, como a quantificação dos trade-offs e a análise de sensibilidade. Apesar da consolidação não ter sido realizada na própria reunião, foram levantados na entrevista os principais pontos que deveriam fazer parte da análise de sensibilidade. Foi definido que a análise seria focada nos pontos de virada do modelo, primeiramente alterando as preferências de Custo à Benefício e depois medindo a 
diferença existente entre a opção de maior e menor custo. O resultado da aplicação deste processo está detalhado no próximo capítulo. 


\section{RESULTADOS}

A condução da análise dos resultados será dividida em três etapas, de acordo com a metodologia proposta por Franco e Montibeller (2010). A primeira será a Estruturação do problema, onde se descreve o escopo, o negócio e as estruturas observadas no mercado. Posteriormente, parte-se para a construção do modelo, tendo como base a o estudo de caso. A terceira etapa será conduzida com uma discussão e análise dos resultados da aplicação na Trading.

\subsection{Estruturação do problema}

A proposta deste trabalho foi a identificação de um problema comum ao agronegócio e sua posterior aplicação a um caso específico proposto pela Trading. Por isso, a primeira etapa exploratória, através da aplicação de questionários semiestruturados com 11 gerentes de empresas embarcadoras, foi fundamental descrever o mercado de transporte rodoviário.

O objetivo da etapa foi levantar informações para elaboração do problema, melhor conhecimento do ambiente e definição da empresa para a aplicação do estudo. As entrevistas levantaram uma gama de operações diversas, sendo que o local de atuação, cultura da empresa, portfólio de produtos, estrutura de armazenagem e processamento diferenciavam significativamente os embarcadores.

Um ponto em comum entre as empresas foi a incerteza em relação ao cenário logístico atual. Os entrevistados se questionavam acerca do modelo predominante rodoviário e a dependência dos transportadores que estão aplicando reajustes no frete para recomposição dos custos. Após a implementação da Lei $n^{\circ}$ 12.619/12, muitas destas empresas tiveram reajustes superiores a 30\% no valor do frete, o que reduziu significativamente a competitividade. De uma maneira geral, a dependência do modal rodoviário foi colocada em cheque, porém a sua flexibilidade e a falta de opções intermodais ainda obrigam as empresas a reverem as estratégias neste modal.

As entrevistas (disponíveis no Anexo I) apontaram para uma série de arranjos de governança existentes no mercado, conforme apontado na Tabela 02. Pelo que foi constatado não existe predominância de um modelo entre as empresas e dificilmente uma única alternativa é capaz de atender a demanda. Porém, para serem competitivos, 
os embarcadores procuram revisitar suas estratégias para ajustá-las aos investimentos em logística.

\begin{tabular}{l|ccccc|} 
& Verticalização & Parcial & Subcontratação & Contratos & Spot \\
\hline Empresa 01 & & & Sim & Sim & Sim \\
Empresa 02 & & & Sim & Sim & Sim \\
Empresa 03 & Sim & Sim & Sim & Sim & Sim \\
Empresa 04 & & Sim & Sim & Sim & Sim \\
Empresa 05 & & & & Sim & Sim \\
Empresa 06 & & & & Sim & Sim \\
Empresa 07 & & & Sim & Sim & Sim \\
Empresa 08 & & & & Sim & Sim \\
Empresa 09 & & & Sim & Sim & Sim \\
Empresa 10 & Sim & & & & Sim \\
Empresa 11 & & Sim & & &
\end{tabular}

Tabela 02 - Estratégias de verticalização observadas nas entrevistas.

De maneira mais detalhada, serão descritos na sequência os arranjos de coordenação vertical que foram observados na etapa exploratória.

\section{Verticalização}

A integração vertical total é pouco observada no transporte rodoviário de granéis sólidos. Entretanto, em alguns modelos de negócio, esta prática tem ganhado destaque, mas ainda em pequena escala. $\mathrm{O}$ transporte de carga própria (onde não existe prestação de serviço por um terceiro) possui alguns benefícios fiscais como a não cobrança dos tributos que são incidentes neste tipo de serviço (PIS/COFINS, ICMS e ISS quando aplicáveis) e permite a apropriação de créditos fiscais dos insumos, quando existirem. Estes veículos não precisam ser registrados na ANTT, pois transportam apenas mercadoria própria; portanto, não há um número oficial do tamanho desta frota. $\mathrm{O}$ frete da mercadoria, neste caso, é o próprio custo de transporte e uma das barreiras observadas foi a maneira de contabilizar e ratear os custos no momento da precificação do produto.

Entre as restrições observadas, a perenidade da demanda e as sinergias entre as operações origem-destino são mandatórias. Possuir cargas para trafegar nos trajetos de ida e volta carregado não é algo simples, pois os produtos são movimentados em períodos e escalas diferentes, o que impede o melhor aproveitamento do ativo. Isso exige que o veículo transite vazio para retornar à origem, ou faça o aproveitamento do retorno prestando serviço para um terceiro. 
A expertise no transporte e a gestão da frota/motoristas fazem desta atividade algo extremamente trabalhoso e distante do foco principal da empresa. As responsabilidades civis (em caso de acidentes) e trabalhistas também geram desconforto aos gestores das empresas embarcadoras, que alegam a necessidade de haver uma equipe dedicada com a mesma prática de uma transportadora do mercado para exercer esta atividade. Além disso, antes da implementação da Lei $\mathrm{n}^{\circ}$ 12.619/12, os custos com horas-extras, adicionais com hospedagem, entre outros custos, oneravam demasiadamente as despesas com mão-de-obra, frente a um mercado que desprezava estas obrigações. A concorrência, que suprime tais responsabilidades, acaba sendo mais eficiente (do ponto de vista econômico) que o embarcador que não tem como acompanhar tal prática.

Pequenos embarcadores mais verticalizados (inclusive na produção agrícola) podem vir a operar em uma escala maior. O uso múltiplo dos veículos é apontado por um dos entrevistados como um grande benefício: “os caminhões são utilizados para fazer a colheita, transportar os fertilizantes e levar os produtos finais até os clientes. Caso falte volume para movimentar a frota, o veículo trabalha para terceiros no mercado spot, o que ajuda a diluir os custos fixos".

Concluindo, a operação própria exige uma combinação especial entre perenidade da rota, produtividade (aproveitamento do veículo), controle e competitividade entre custo versus frete de mercado.

\section{Parcial}

A integração vertical parcial é mais comum que a verticalização total e está frequentemente associada a uma relação contratual de prestação de serviço. Neste caso existem dois modelos distintos, sendo o primeiro a aquisição do conjunto completo e o segundo apenas o implemento. Em ambos, existe uma prestação de serviço regida plenamente pela Lei $\mathrm{n}^{\mathrm{o}} 11.442 / 07$, sendo o ativo cedido do embarcador para $\mathrm{o}$ transportador por meio de um contrato de arrendamento ou comodato. Existe uma negociação do frete e uma negociação do arrendamento do veículo, que é abatida do frete final.

Os grandes benefícios desta prática são as amarrações contratuais que fidelizam o transportador. Em alguns modelos o transportador é definido como "agregado" e os veículos são identificados como "a serviço do embarcador". 
Dois fatores observados contribuem para o uso desta estratégia: uso de créditos de ICMS para a compra de caminhões e a negociação em escala dos ativos com um valor reduzido. Esta combinação entre a verticalização total e o contrato de longo prazo culmina em um modelo que teoricamente alia a necessidade do embarcador com a habilidade do transportador.

Na participação parcial, o embarcador possui apenas os implementos. Essa prática é eficiente em mercados sazonais e com multiplicidade de demandas para os cavalos mecânicos. Por exemplo, se uma carroceria do tipo Graneleira se torna ociosa nos meses de outubro a fevereiro, o cavalo mecânico é desacoplado do implemento Graneleiro e se acopla a uma carreta do tipo Sider que possui maior demanda no verão (transporte de bebidas, por exemplo). Nos Estados Unidos, normalmente as carrocerias pertencem aos embarcadores e operadores logísticos (terceirizados) e os transportadores autônomos possuem apenas o cavalo mecânico. Os ganhos deste modelo são a maior produtividade do veículo, mão-de-obra e menor tempo operacional na carga e descarga.

O modelo parcialmente integrado é interessante pois alia flexibilidade, fidelidade e produtividade. No cenário atual ele é pouco difundido e está altamente relacionado com a existência de contratos formais, principalmente por causa do arrendamento do ativo.

\section{Subcontratação}

A subcontratação do transporte é um modelo amplamente utilizado por embarcadores de grãos. Neste caso, ao invés da contratação de um agente de cargas ou transportador misto, subcontrata-se diretamente um pequeno frotista, pessoa física ou jurídica. A operação exige uma entidade legal que tenha como atividade fim o transporte rodoviário de cargas e consequentemente estrutura de receitas e despesas, funcionários e lucro separados da entidade contratante da matriz (o próprio embarcador).

Esta empresa, ora denominada também como Transportadora, irá terceirizar apenas o transporte, ficando responsável pelo restante do serviço embutido na prestação. A atividade de agenciamento e subcontratação de pequenos frotistas (TAC / ETC / CTC) sobrecarrega as rotinas administrativas deste transportador que não conseguiria atuar através contratação direta. Ao se analisar a frota média dos transportadores de carga, chega-se a um resultado de aproximadamente 8 veículos por transportador, o que é um 
número muito pequeno para um grande embarcador que precisa ter uma frota de mais de 1.000 veículos dedicados para atender sua demanda.

Este pequeno frotista (mesmo que pessoa jurídica) atua como se fosse um autônomo ou motorista eventual, procurando cargas no mercado e migrando para onde há demanda. Esta relação é pouco formalizada por contratos e o frete é determinado pelo preço do mercado no dia. Os locais onde a transação é realizada são os postos estradeiros (Figuras 11 e 12), onde as grandes agências de carga possuem escritórios informando a oferta de cargas. Os motoristas são os principais tomadores de decisão sobre qual frete escolher, pois parte do salário do empregado é determinado por um percentual do faturamento do caminhão.

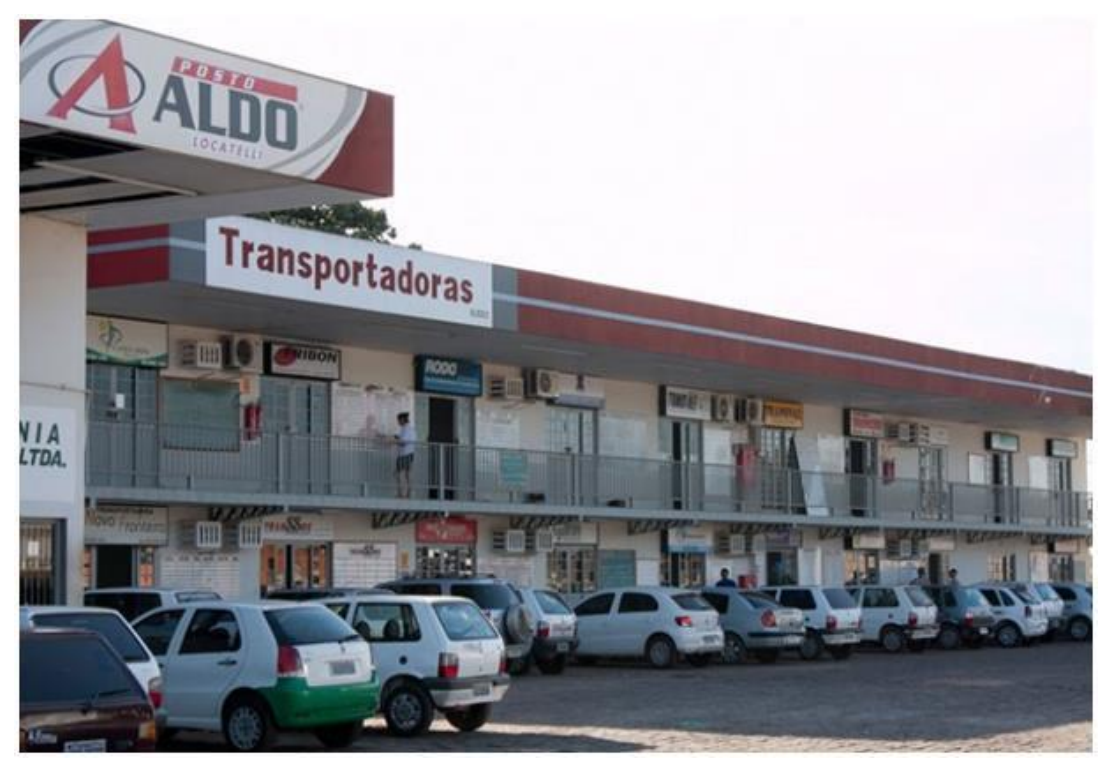

Figura 11 - Auto Posto Locatelli em Rondonópolis. 


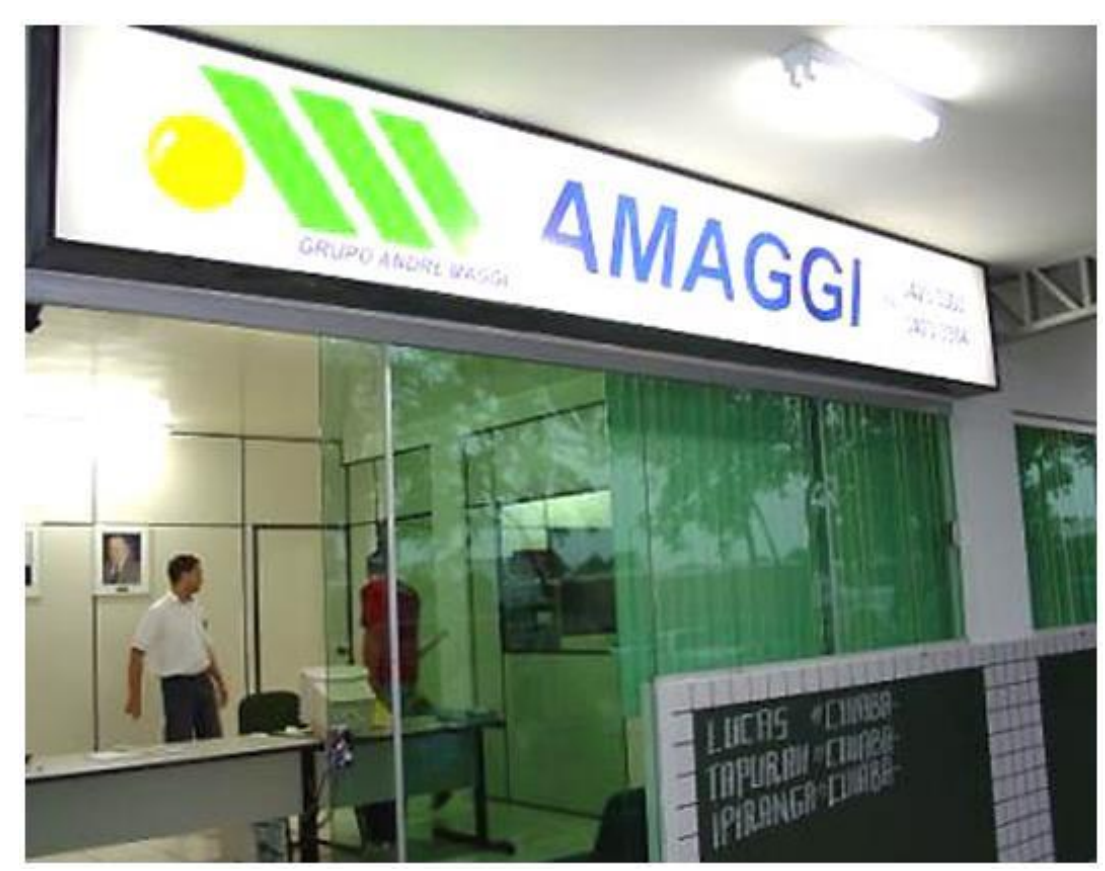

Figura 12 - Detalhe da sala da Transportadora da Amaggi.

Ao escolher um frete, o motorista recebe da Transportadora uma ordem de carregamento indicando o local de coleta (expedidor da mercadoria) e o destino da prestação (recebedor). Esta ordem não é um documento fiscal e serve apenas como uma autorização de carregamento. Para reduzir os incidentes de roubo de cargas, muitas seguradoras exigem que os motoristas possuam cadastro em empresas especializadas na consulta de antecedentes criminais e pendências financeiras. Dependendo dos apontamentos e dos requisitos exigidos pela seguradora, o motorista pode ser recusado para a prestação do serviço.

Ao finalizar o carregamento e emitir a Nota Fiscal, o embarcador transmite a posse da mercadoria à Transportadora. Para iniciar o transporte da mercadoria, a Transportadora emite contra o embarcador um Conhecimento de Transporte e imprime uma via da DACTE que acompanha a DANFE durante a circulação da mercadoria. Também é obrigação da Transportadora emitir o MDF-e, destacando a relação de documentos contidos no veículo.

Nestes documentos fiscais devem constar todas as informações relativas ao valor da prestação do serviço, tomadores de serviço e demais obrigações da subcontratação. A Transportadora que subcontrata o transporte é responsável pela emissão do Vale Pedágio obrigatório, apólices de seguros da carga (RCTRC e RCF-DC), emissão do 
CIOT e Pagamento Eletrônico do Frete (se TAC/equiparado), estes últimos amparados por um Contrato de Transporte que transmite o acordo celebrado entre a Transportadora e o Subcontratado. As principais ressalvas dispostas no contrato são o valor do serviço, o percentual de adiantamento do frete, o acordo do valor de estadia e as informações relevantes para a viagem específica. Quando é subcontratado um TAC/equiparado, também é obrigação da Transportadora fazer o recolhimento antecipado de IR, INSS e Sest/Senat, além do respectivo depósito dos valores nas contas dos órgãos responsáveis.

No início da viagem, é uma prática comum dos motoristas utilizarem um adiantamento do frete para suprir as despesas, principalmente de combustível. Este adiantamento varia de acordo com a política do transportador e região de atuação, mas dificilmente supera $80 \%$ do valor total da prestação do serviço. A gestão dos pagamentos, neste caso, é normalmente realizada por um administrador de fretes homologado pela Resolução $\mathrm{n}^{\circ}$ 3.658/11 e o valor de adiantamento pode ser feito via saque no Banco ou através do consumo do cartão do meio de pagamento.

Ao finalizar a entrega, o motorista direciona-se a um local estabelecido para realizar o processo de quitação. Nesta etapa o motorista apresenta o canhoto da nota físcal assinado, tíquete de pesagem, entre outros documentos exigidos para comprovação da entrega. Se não houve quebra de peso no destino, o saldo do frete é disponibilizado ao subcontratado dentro do prazo pré-estabelecido. Qualquer desconto ou indenização nos dispostos do contrato de frete também são contabilizados na quitação. É comum que este processo seja realizado em um posto de combustível próximo do local onde foi feita a entrega, na maioria das vezes, muito distante do local onde a carga foi embarcada. Nestes casos os documentos são encaminhados para a Transportadora contratante para conferência e somente depois da auditoria o processo é finalizado perante o Embarcador. O fluxo de documentos descrito está esquematizado no fluxograma detalhado da Figura 13. 


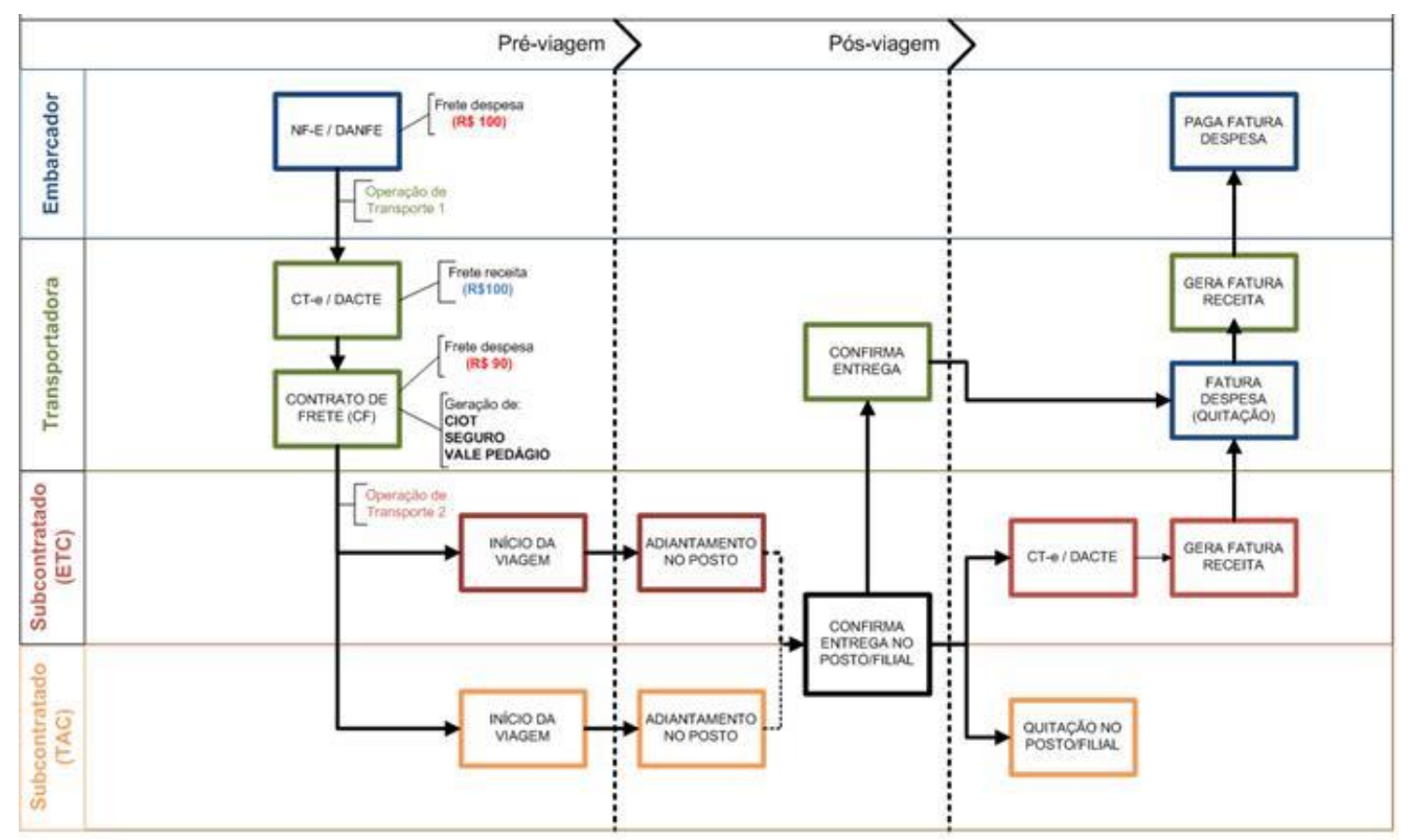

Figura 13 - Fluxograma da subcontratação de transporte (elaborado pelo autor).

A Subcontratação exige uma série de serviços administrativos. A contrapartida financeira, de acordo com os entrevistados, é muito positiva para os embarcadores e frotistas, uma vez que o custo de agenciamento pago ao mercado é variável, sendo cobrada uma margem bruta de 8 a $20 \%$ sobre o frete motorista. Apesar da contratação direta deste pequeno frotista ser possível, a burocracia para emissão de documentos em larga escala e a eventualidade do mercado de terceiros impede a viabilidade desta solução. Fazer o papel do intermediário é uma maneira de conciliar o ganho de competitividade do embarcador (reduzir a despesa com frete) e oferecer uma remuneração maior ao terceiro. A redução da assimetria informacional foi destacada como um grande diferencial deste modelo, pois segundo os entrevistados que possuem a Transportadora própria, eles conseguem acompanhar o mercado diariamente e negociar antecipadamente se comparado a um transportador misto ou agência. Ao se contratar um intermediário, a negociação com os embarcadores é pouco frequente, o que pode inflacionar o frete, uma vez que o objetivo do agente é a maximização da sua margem.

\section{Contratos}

A presença de contratos no transporte de granéis sólidos agrícolas não é destacada na literatura, principalmente devido à confidencialidade da informação mantida entre os 
embarcadores. Os principais exemplos disso são as negociações de transporte ferroviário, que não possuem nenhuma publicação oficial das tarifas praticadas devido ao cunho estratégico da informação. No modal rodoviário os contratos são mais frequentes e existem diversos modelos operantes. Entre eles, se destacam a negociação fundamentada em planilhas de custo e a negociação baseada no mercado spot.

Quando negociado em custo, o contrato costuma exigir o uso da frota própria para cumprimento do serviço, com salvaguardas de produtividade que fazem parte da valorização do frete. Esta negociação exige a dedicação da frota, penalidades por descumprimento e remuneração pelo veículo parado. Além disso, o período contratual desta opção costuma ser no mínimo semestral, podendo ser anual e não maior que 5 anos. Em operações com alto controle e produtividade, sem abundância de frete de retorno, esta opção é bastante interessante. Entretanto, tais condições concorreriam com a verticalização total.

As negociações baseadas em mercado consideram que o valor do frete sofrerá uma oscilação, portanto, uma curva de fretes que varia ao longo do ano. O benefício desta opção é uma cotação futura do frete, uma vez que não há indexador oficial. É um modelo muito comum para o período de pico de safra e costuma ter tarifa e volume definidos para um período de no mínimo 3 meses, podendo chegar a um ano se a tarifa for variável. As garantias apresentadas para este tipo de contrato são a frota do transportador; porém, dependendo do valor que o mercado estiver remunerando o ativo, podem haver rompimentos contratuais.

As modalidades de contratos de longo prazo são muito interessantes para o atendimento da demanda; todavia, é possível que as incertezas de mercado adicionem custos ex-ante que comprometam a competitividade do embarcador. Na possibilidade do contrato estar posicionado com um frete muito abaixo do mercado, os custos ex-post (rompimento do contrato, por exemplo) podem ser ainda mais prejudiciais, uma vez que a execução será feita mediante um prejuízo para toda a cadeia logística. Entre as alternativas, a contratação de longo prazo é sempre mais interessante em cenários com maior previsibilidade e regulação, pois a incerteza costuma elevar os custos de frete. 


\section{Spot}

O mercado de fretes spot é determinado basicamente pela oferta e demanda observada para as rotas praticadas. A decisão para escolher este modelo baseia-se na expertise de leitura do mercado de fretes ou na impossibilidade de um planejamento determinado das operações.

A execução do serviço neste modelo não é necessariamente feita pela frota do contratado, que na maioria das vezes é destinada para cumprimento dos compromissos de longo prazo. O transporte é realizado em sua maioria por um subcontratado que recebe um frete motorista com o valor cotado para o dia. $\mathrm{O}$ transportador que vendeu $\mathrm{o}$ serviço ao embarcador pratica um desconto no frete-empresa na ordem de 8 a $20 \%$ para subcontratar terceiros e caso seja necessário, utiliza a sua frota apenas para cumprimento da contratação quando há escassez de terceiros.

Apesar do grande risco de preços por não haver um indexador oficial, diversos são os motivos dos embarcadores optarem por esta alternativa. A flexibilidade oferecida por grandes transportadoras permite uma maior visibilidade e informação do mercado para embarcadores com atuação local ou regional, afinal estes transportadores conseguem captar veículos em diferentes localidades do país. Além disso, esta opção não exige estrutura física para contatar o transporte e consegue atender a demanda do dono da carga.

Independente do valor de agenciamento pago a um intermediário, esta estratégia pode viabilizar muitos negócios com um baixo risco. Os custos ex-post no caso de rompimento contratual ou responsabilidade legal podem significar riscos, mas considerados baixos pelos entrevistados. De modo geral, esta é a principal estratégia adotada por pequenas empresas que possuem pouca quantidade de fábricas/armazéns e volume muito sazonal ao longo do ano. Frequentemente é mais competitiva em mercados informais (ou com pouca fiscalização), onde ainda há predominância da cartafrete, rotas de curta distância (baixo valor do frete) e onde existe alta participação de autônomos (pessoa física, uma vez que, ao usar a carta frete não são recolhidos os encargos incidentes na operação).

A comparação entre os arranjos de governança não é uma tarefa fácil, principalmente se o problema não estiver bem definido. Por isso, o estudo de caso elaborado junto a 
Trading elucidou muito o entendimento do trade-off Custo x Benefício. Na visão do embarcador o objetivo do negócio (comercialização de grãos) não é necessariamente possuir o menor frete, mas sim o frete que proporciona a melhor margem de contribuição entre a comercialização e execução.

A Figura 14 mostra que a logística é a grande responsável por promover a competitividade no sistema da Trading. Dentro da empresa existe uma área específica também denominada por trading, responsável pela comercialização internacional dos produtos, que solicita para uma área de originação a compra da matéria prima. Para precificar o produto, a originação utiliza o preço do trading no porto descontados os custos de frete. Após a compra da mercadoria a logística é a responsável pela movimentação até o porto, devendo realizar o serviço com a maior qualidade possível, menor custo e respeitando os prazos acordados com os clientes. No diagrama a seguir, percebe-se que no ato de precificação existe uma percepção maior do Custo, e durante a execução a percepção do Benefício é maior.

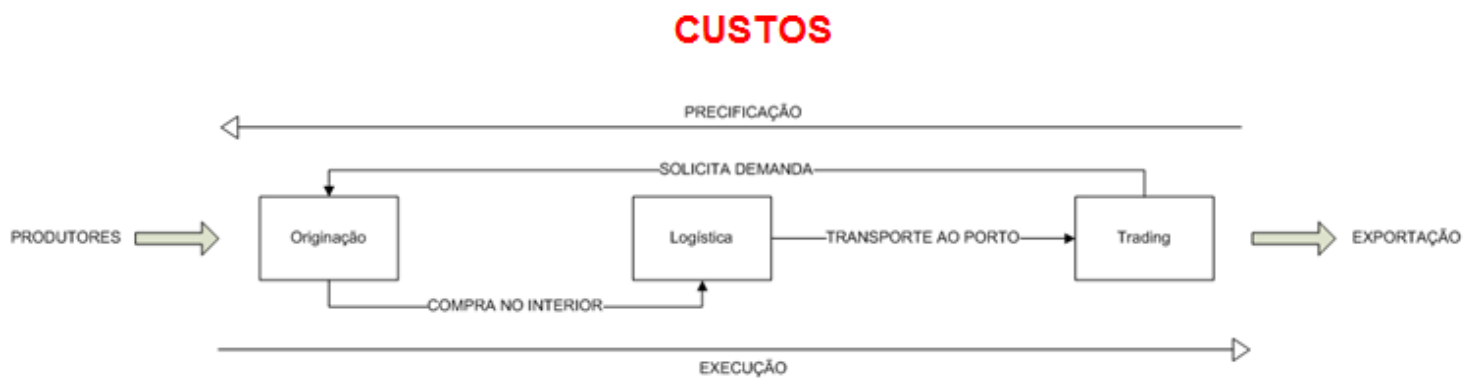

\section{BENEFícIOS}

Figura 14 - Trade-off Custo x Benefício observado no ambiente da Trading.

A logística atua entre as áreas de originação e trading, tanto na precificação da matéria prima como na execução do transporte. O frete ao porto é um dos componentes mais importantes utilizados para a composição da lista de preços pagos pelos grãos no interior. Por exemplo, se o preço FOB da soja em Paranaguá/PR é de US\$ 600.00/tonelada e o frete a partir de Sorriso/MT para Paranaguá/PR é de US\$ 150.00/tonelada o valor máximo que a empresa poderia pagar pela soja em Sorriso/MT seria de US\$ 450.00/tonelada. Excluindo os efeitos de oferta e demanda local em Sorriso/MT e entendendo que este seria o preço médio de frete encontrado pelo mercado, caso algum embarcador conseguisse uma alternativa logística com menor 
custo, ele teria condições de ofertar um valor maior pelo produto e ser mais competitivo na originação. $\mathrm{O}$ mesmo comportamento poderia se refletir no preço do produto no porto: o frete mais competitivo poderia refletir uma venda a um preço menor ao cliente e reduzir os custos totais da cadeia logística.

Ainda analisando a Figura 14, pode-se observar a relevância da execução da compra e do transporte ao porto. Após o fechamento de uma venda na exportação, o trading solicita à originação que compre soja dos produtores. A composição do preço é feita para auxiliar as negociações no interior e o frete é um componente com altíssima importância e determina a competitividade da Trading perante à concorrência. Este custo logístico pode ser minimizado através da estratégia de logística como um todo, incluindo a saída marítima, modal de transporte utilizado e o tipo de governança escolhido para o transporte rodoviário. Segundo um dos entrevistados a percepção é obtida através dos mecanismos de preços, “o produtor entende que até R \$ 0,25/saca não há grande diferença entre as ofertas praticadas pelo mercado; caso esta diferença chegue a R \$ 0,50/saca, ele só vende caso exista uma relação muito grande com a empresa; caso esta diferença seja acima de R \$ 1,00/saca, não há negócio fechado ou ele vende somente se ele não tiver alternativa".

Após a compra realizada, inicia-se o processo de execução (entrega da venda no porto). Muitas vezes o lote comprado foi negociado para embarque futuro, ou seja, a venda foi realizada em outubro de um ano para embarque em março do ano seguinte. À medida que os navios estiverem prontos para embarcar e o produto estiver disponível na fazenda, a logística inicia o processo de contratação do frete. É importante notar que apesar da formação do preço do produto ter o frete na sua composição, não necessariamente há um fechamento do valor do frete com os transportadores no mesmo momento. Outro entrevistado da Trading mencionou que devido a este descasamento entre compra e execução, "o objetivo da logística é gerenciar riscos". Este fator reflete exatamente o trade-off Custo x Benefício e, segundo ele, pode resultar em algumas situações apresentadas a seguir:

a. Frete da precificação maior que o frete do mercado resulta na não realização de negócios, ou seja, a logística inviabilizou o negócio da Trading que não conseguiu comprar o produto e nem atender o cliente de exportação, portanto não houve execução. 
b. Frete da precificação inferior ao preço do mercado gerou muitos negócios, porém durante a execução o frete estava mais elevado que o precificado. A decisão da empresa foi de não arcar com o prejuízo e não foi possível realizar a execução dentro do prazo combinado.

c. Frete da precificação inferior que o valor de mercado gerou muitos negócios, porém durante a execução o frete estava mais elevado que o precificado. A decisão da empresa foi de arcar com o prejuízo, pois o custo do não atendimento seria mais elevado que a diferença de frete.

d. Frete da precificação dentro do valor praticado pelo mercado, porém durante a execução o frete estava mais elevado que o precificado. A decisão da empresa foi de não arcar com o prejuízo e não foi possível realizar a execução dentro do prazo combinado.

e. Frete da precificação dentro do valor praticado pelo mercado, porém durante a execução o frete estava mais elevado que o precificado. A decisão da empresa foi de arcar com o prejuízo, pois o custo do não atendimento seria mais elevado que a diferença de frete.

f. Frete da precificação dentro do valor praticado pelo mercado, tendo a execução ocorrida de acordo com o combinado.

Entre as seis situações mais comuns apresentadas, uma delas (a) não gerou negócios em um momento devido aos custos ex-ante; duas delas (c/e) viabilizaram o negócio mas agregaram custos ex-post; outras duas (b/d) não alavancaram custos diretos, porém tiveram consequências em queda do nível de serviço e reputação; apenas uma delas (f) referiu-se à execução dentro do preço e prazo acordados. Nota-se claramente que a estratégia logística pode ser afetada por inúmeros fatores e que o custo de frete pura e simplesmente não é uma maneira adequada para se tomar decisões. Entre as alternativas já apresentadas, algumas delas possuem melhor ou pior performance em relação à matriz Custo x Benefício e o trabalho desenvolvido permitiu que os stakeholders tomassem decisões com maior clareza e embasamento.

O grupo de Gerentes da Trading definiu durante a primeira reunião que o problema a ser resolvido seria "encontrar um arranjo estratégico que maximize a margem de contribuição da empresa através de um atendimento logístico que atenda as demandas do negócio e que se mantenha competitivo no longo prazo”. Entende-se por margem de 
contribuição da empresa o resultado final da atividade de compra e venda de grão; por executar a demanda do negócio a execução do programa de originação e trading; por manter-se competitivo no longo prazo equivalente a possuir o menor frete do mercado.

Para delimitar o escopo, conforme mencionado no material e método, escolheu-se uma rota rodoviária extremamente representativa para o segmento, que é a rota com origem na região da BR-163 no Mato Grosso com destino ao transbordo intermodal na Ferronorte. Deste ponto em diante a mercadoria segue para o porto de Santos/SP através da ferrovia, sendo que este trecho do transporte não fez parte do estudo. A delimitação do estudo foi dimensionada para a movimentação constante e linear de $40 \%$ do volume anual da Trading com base no ocorrido no ano de 2013, sendo que este volume representou o menor volume mensal movimentado pela empresa neste ano.

A escolha de 2013 foi porque neste ano a empresa realizou um estudo completo de custos para operacionalização de uma frota própria e também optou pela realização de contratos de longo prazo. Como já existia a publicação do frete spot praticado pelo mercado no Sifreca (2013), foi possível obter-se os custos das demais alternativas disponíveis. Considerou-se que o custo da subcontratação trata-se de um desconto de aproximadamente 3\% abaixo do frete empresa spot, e que a verticalização parcial com ativos operados por terceiros aplica um prêmio de $5 \%$ acima do custo da subcontratação, há como se obter os valores médios destas alternativas para este ano em específico.

\subsection{Construção do modelo}

Utilizando as premissas apresentadas na seção anterior, iniciou-se o processo de estruturação da modelagem. Esta etapa tem o objetivo de organizar as informações em uma estrutura de árvore com os atributos e os objetivos claramente definidos. Como a abordagem deste problema foi baseada em alternativas existentes no mercado (AFT), conforme apresentadas na seção anterior, os objetivos e atributos devem ser capazes de classificá-las de acordo com as preferências dos tomadores de decisão. O grupo decidiu que trabalhar com as alternativas existentes era uma boa opção, pois eram conhecidas por todos. Chegou-se a discutir alternativas futuras como a terceirização de mão-de-obra por intermédio de cooperativas ou até um agenciamento terceirizado, mas como estas alternativas não existem, seria muito ambíguo atribuir valores e avaliá-las. 


\subsubsection{Criação dos objetivos fundamentais}

O objetivo fundamental definido pela Trading foi a escolha da melhor estratégia em relação a Custo e Benefício. Estes subcritérios foram tratados de maneira independente para a avaliação das alternativas. O risco inerente da cada estratégia não foi considerado uma vez que os riscos da atividade impactam da mesma maneira todas as estratégias e os riscos acerca das responsabilidades legais e ambientais podem ser mitigados por meio da contratação de um seguro e, portanto, incorporado no valor total.

O subcritério Custo foi descrito como a minimização dos custos totais com frete presentes na operação. Para fins de análise, os custos foram mensurados na escala de R\$/TKU (Tonelada Quilômetro Útil), ou seja, o custo de se movimentar uma tonelada em uma distância de $1.000 \mathrm{~km}$. Os custos de transação presentes em cada uma das estratégias foram incorporados na variável frete e, portanto, estão embutidos no custo total. Os valores foram obtidos a partir de dados fornecidos pela Trading.

O subcritério Benefício está relacionado à maximização da capacidade de execução, como o cumprimento da demanda solicitada pela área de trading e a realização do embarque da compra/venda realizada dentro do prazo. Este subcritério será desmembrado em uma série de outros atributos capazes de explicar melhor a percepção de Benefícios pelo embarcador.

Para ponderar a relação Custo x Benefício foi realizado, durante a aplicação, um processo de balanceamento da preferência dos gestores, ou seja, quanto o Custo vale em relação ao Benefício para se atingir o objetivo global. Inicialmente, a proposta dos gestores era um rateio igual (50/50) entre Custo e Benefício, uma vez que a qualidade da execução seria tão importante quanto à competitividade. Considerando o grande volume transportado e a baixa qualificação do setor, na opinião dos grupos de gestores da Trading, a qualidade da execução é menos relevante que o custo, dado que o frete é o componente que garante a compra da matéria prima. Por isso, conforme exposto na Figura 15, a relação adequada foi de $70 \%$ para o Custo e 30\% para Benefício. 


\section{CUSTO}

BENEFÍCIO

\section{1}

Figura 15 - Ponderação Custo x Benefício do modelo.

Apesar da relação fixada neste primeiro momento, os tomadores de decisão podiam mudar a estruturação do problema e consequentemente o peso de cada critério na função objetivo.

\subsubsection{Desenvolvimento dos atributos}

Os atributos são os critérios específicos capazes de explicar o objetivo de maneira quantitativa, com maior ou menor relevância na opinião dos stakeholders. As análises apresentadas a seguir têm o objetivo de descrever os atributos (subcritérios) para a posterior aplicação do método.

1) Custo: como já mencionado, a variável Custo foi dada pela Trading e trata-se do valor de frete pago para a movimentação de uma tonelada em um percurso de $1.000 \mathrm{~km}$ na rota da BR-163 para a Ferronorte. Os valores obtidos foram transformados na unidade $\mathrm{R} \$ / \mathrm{saca}$ de soja $(60 \mathrm{~kg})$ e trabalhados como um desconto no valor do produto. Algumas premissas foram importantes para chegar a estes valores: o valor spot foi baseado no frete médio observado pelo Sifreca (2013) ao longo do ano de 2013; o custo do contrato refere-se ao preço pago pela Trading no ano de 2013; os custos operacionais da subcontratação foram obtidos aplicando-se um desconto líquido de 3\% sobre o frete spot, já inclusos os custos de operacionalização deste modelo; a verticalização parcial apresenta um custo 5\% superior ao valor da subcontratação; e, para definição do custo da verticalização total foi modelado um custo operacional de 217 veículos do tipo Rodotrem Graneleiro, simulando uma operação de 4,6 viagens/mês e considerando uma remuneração de capital de 12\%, conforme exposto na metodologia apresentada por Lima (2005).

\section{2) Benefício:}

a. Atendimento da demanda: cumprir com a solicitação no prazo desejado, sem transtornos e entregar o produto nas condições acordadas. Possui 
alto desempenho neste atributo a alternativa que atende a demanda sempre conforme o combinado, e baixo desempenho quem não apresenta compromisso para o atendimento solicitado.

b. Adequação de frota: qualidade da frota (idade média baixa, tamanho adequado às dimensões de balança / moega / tombador, configuração de alta produtividade). Possui um alto desempenho deste atributo uma frota bem dimensionada para as estruturas existentes, e baixo desempenho para uma frota sem nenhum tipo de padronização.

c. Gestão e controle: se traduz pela competência de controlar o serviço executado, possuir flexibilidade para se ajustar às demandas de cadência, e alteração de programação e deslocamento da frota. A preferência por este critério se dá pelos controles de execução antes, durante e depois do embarque, possuindo flexibilidade para deslocar a carga para onde for necessário. O menor nível aceitável para este critério é apenas o gerenciamento antes do início da viagem e o controle de que as cargas chegaram ao destino mesmo que sem controle da mercadoria em trânsito.

d. Capacidade de Inovação: a inovação no transporte está associada à liberdade para se criar modalidades mais econômicas e eficientes. A alta capacidade de inovar está associada à necessidade gerada pela pressão de custos e à possibilidade de adaptar a frota existente a configurações mais competitivas. A baixa capacidade de inovação está em ambientes onde há menor pressão para mudanças ou com menor flexibilidade para realizar a atualização dos ativos.

e. Know-how adquirido: o ganho de conhecimento adquirido pode ser observado pela participação das partes na execução do transporte. Na visão do embarcador, seria a alternativa que proporciona maior conhecimento do negócio e por isso promove inteligência competitiva. As características da alternativa que possui melhor desempenho neste quesito são as que possibilitam o maior ganho de competências no longo prazo, sendo as que não alavancam conhecimento detentoras de um pior desempenho.

A ponderação da participação destes atributos para explicar o subcritério Benefícios também foi desenvolvida durante o primeiro encontro realizado na Trading. Conforme 
apontado na Figura 16, o atributo mais relevante na opinião do grupo foi a qualidade de atendimento da demanda. Posteriormente, a gestão e controle mostrou-se bastante relevante, seguido da adequação de frota, capacidade de inovação e know-how adquirido. A descrição de cada critério, assim como as respectivas curvas de valor, serão detalhadas na seção 4.3.

ATENDIMENTO DA DEMANDA

ADEQUAÇÃO DE FROTA

CAPACIDADE DE INOVAÇÃO

GESTÃO E CONTROLE

KNOW-HOW ADQUIRIDO

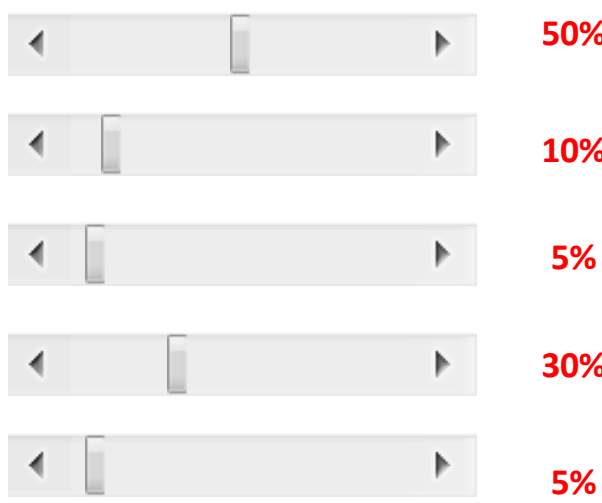

Figura 16 - Ponderação dos atributos do subcritério Benefício.

Nota-se que estes atributos somados devem refletir a preferência global dos tomadores de decisão para a avaliação das estratégias logísticas. Novamente o grupo mostrou-se bastante focado à capacidade de execução e por isso fatores mais qualitativos mostraram-se menos relevantes.

\subsubsection{Construindo a árvore de valores}

Após a definição dos subcritérios e seus respectivos atributos, o problema foi estruturado no formato de árvore de valores (exposta na Figura 17), construída na plataforma computacional do software V.I.S.A. 


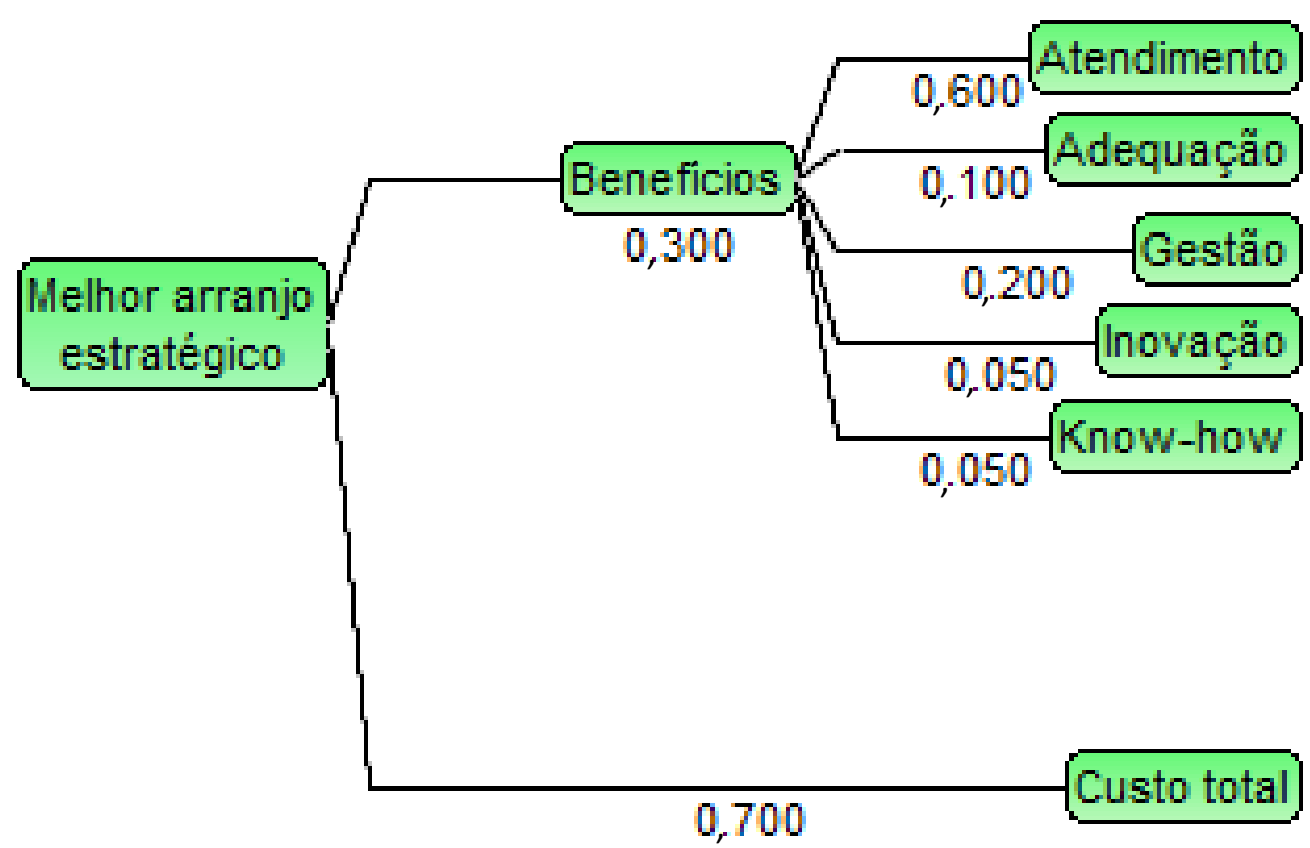

Figura 17 - Árvore de valores do modelo proposto.

Esta árvore demonstra o problema proposto, onde Custo e Benefícios são os critérios da decisão a ser realizada, sendo que a partir do critério Benefícios estão vinculados os respectivos atributos. Durante a próxima seção será possível entender melhor como foram criadas as curvas de valor e como cada alternativa teve o seu desempenho contabilizado no modelo proposto.

\subsection{Modelar as preferências e avaliar as alternativas}

A partir de uma estrutura organizada de árvore, é necessário construir funções de valor para cada atributo desenvolvido no modelo. Este processo permite que os desempenhos de cada atributo sejam avaliados separadamente e possam ter escalas próprias.

O critério Custo certamente é o de maior relevância para o problema e a avaliação do seu impacto na decisão é bastante polêmica. O grupo entendeu que a perda de competitividade na originação de grãos por conta dos descontos de frete seria uma boa medida de eficiência logística. Segundo a aplicação na Trading, o menor custo de frete é sempre o que traz mais competitividade e por isso o impacto na decisão é igual a 100. Considerou-se neste caso que o valor pago ao produtor neste cenário seria de $\mathrm{R} \$$ 50,00/saca. Um desconto de até $\mathrm{R} \$ 0,25 /$ saca não seria tão perceptível, pois teria um impacto de 90. Se o desconto fosse da ordem de $\mathrm{R} \$$ 0,40/saca, o impacto na decisão 
seria equivalente a 70; se fosse próximo a $\mathrm{R} \$ 0,60$ /saca, teria um impacto de apenas 40 . Caso a diferença fosse igual ou maior a $\mathrm{R} \$ 1,00 /$ saca, o único motivo de conseguir se originar grãos neste patamar seria a total falta de espaço ou extrema necessidade de compra do produto, assim, esta opção teria valor 0 . Neste ultimo caso, o valor máximo a se pagar para o produtor seria de $\mathrm{R} \$ 49,00 /$ saca. A Tabela 03 apresenta a consolidação desta análise e foi a base para o desenvolvimento da curva de valor.

\begin{tabular}{ccccc}
$\begin{array}{c}\text { Frete ao porto } \\
(\mathbf{R} \$ \mathbf{t})\end{array}$ & Diferença $(\mathbf{R} \mathbf{\$} / \mathbf{t})$ & $\begin{array}{c}\text { Diferença } \\
\text { (R\$/saca) }\end{array}$ & $\begin{array}{c}\text { Valor pago ao } \\
\text { produtor }(\mathbf{R} \mathbf{\text { saca }})\end{array}$ & $\begin{array}{c}\text { Impacto } \\
\text { atribuído }\end{array}$ \\
\hline $\mathbf{1 5 0 , 0 0}$ & 0 & 0 & 50,00 & 0 \\
$\mathbf{1 5 4 , 1 6}$ & 4,16 & 0,25 & 49,75 & 40 \\
$\mathbf{1 5 6 , 6 6}$ & 6,66 & 0,40 & 49,60 & 70 \\
$\mathbf{1 6 0 , 0 0}$ & 10,00 & 0,60 & 49,40 & 90 \\
$\mathbf{1 6 6 , 6 6}$ & 16,66 & 1,00 & 49,00 & 100 \\
\hline
\end{tabular}

Tabela 03 - Construção da curva de valor para o subcritério Custo.

O resultado desta métrica de avaliação está exposto na Curva de valor do critério Custo e apresentado na Figura 18.

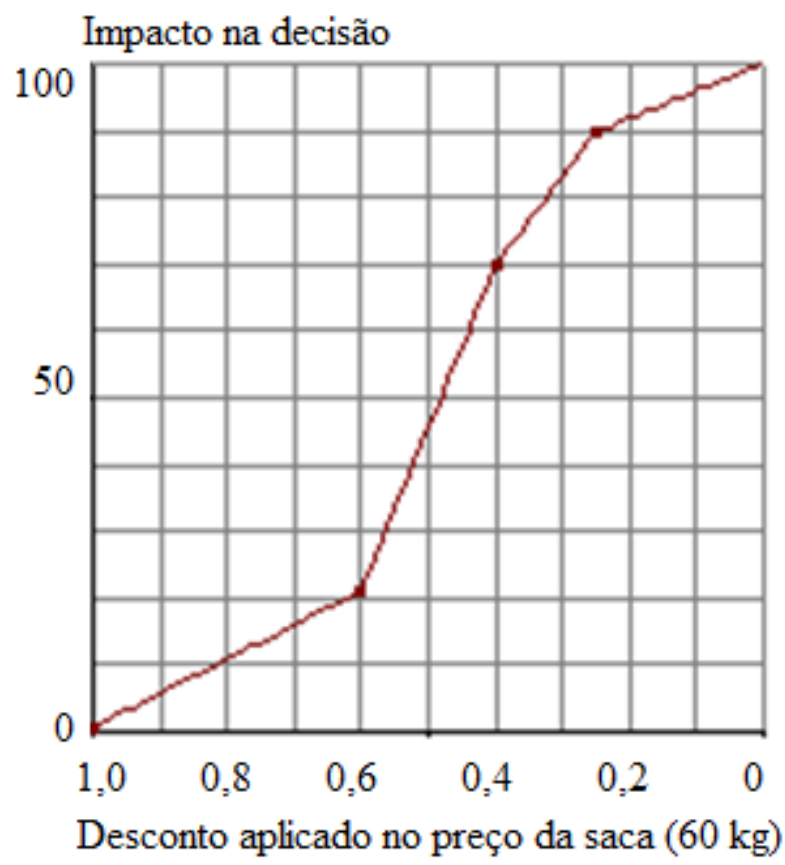

Figura 18 - Curva de valor para o subcritério Custo.

A Figura 19 apresenta a Curva de valor do atributo Atendimento da demanda, que é o segundo mais relevante no modelo. A avaliação foi realizada com base no desempenho da execução que tem como seu máximo desejável o atendimento de $100 \%$ da demanda acordada, e neste caso recebeu pontuação 100. As falhas e atrasos no atendimento 
caracterizam o pior desempenho, porém existe uma grande flexibilidade pela Trading em aceitar um pior nível de serviço, principalmente nos momentos de maior necessidade. Nessas perspectivas, uma aderência de embarque de até $95 \%$ no volume acordado ainda possui uma avaliação de 90 na opinião do grupo. Aderências inferiores a $33 \%$ do volume programado seriam totalmente rejeitadas, recebendo valor 0 , e se fossem na ordem de $60 \%$ o desempenho seria em torno de 50 . Um atendimento de $45 \%$ da demanda dentro do prazo ainda teria um valor de 25 , segundo o grupo. Na Tabela 04 é possível observar o resumo da avaliação realizada para construção desta curva de valor.

Tabela 04 - Construção da curva de valor para o atributo Atendimento da demanda.

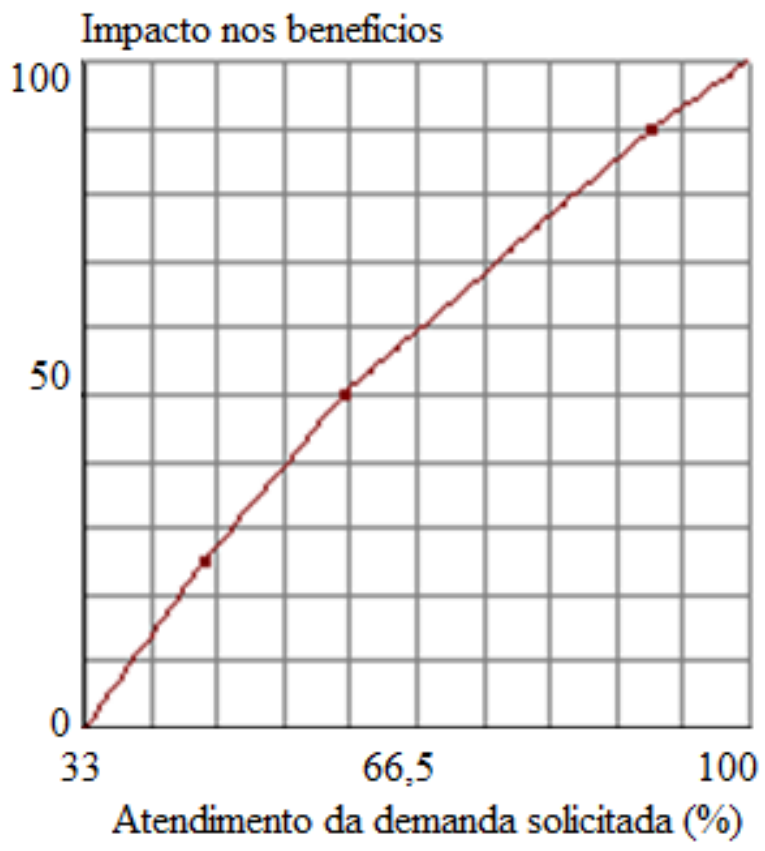

Figura 19 - Curva de valor para o atributo Atendimento da demanda.

O atributo Adequação de frota mostrado na Figura 20 também é altamente flexível, pois na hora de uma necessidade somente uma alternativa totalmente inadequada é rejeitada. Neste caso, uma frota padronizada com alta capacidade de carga é um atributo 
valorizado; porém, até caminhões velhos e com baixa capacidade de carga ainda podem ser tolerados. O melhor desempenho (100) foi dado a uma frota padronizada na plataforma Rodotrem basculante. Com uma avaliação de 90 ficou a opção de trabalhar com uma frota de bitrens e rodotrens graneleiros, muito comum nas grandes transportadoras. O mix médio de caminhões disponíveis no mercado atingiu um impacto de 50 na preferência do grupo, enquanto uma frota antiga com apenas carretas simples e trucadas do tipo graneleira teve um desempenho de 20 na opinião dos gestores. O mix médio de mercado seria uma distribuição de caminhões graneleiros e basculantes nas configurações do tipo carreta, bitrem e rodotrem igualmente distribuídos. O pior cenário, que seria carregar somente caminhões do tipo truck graneleiro, estaria descartado com valor zero. Na Tabela 05 está resumido o processo de construção da curva de valor para este atributo.

\begin{tabular}{ccc} 
Cód. & Adequação de frota & $\begin{array}{c}\text { Impacto } \\
\text { atribuído }\end{array}$ \\
\hline FP & Frota padronizada: 100\% Rodotrens basculantes & 100 \\
FH & Frota heterogênea: $50 \%$ em bitrem graneleiro e 50\% em rodotrem graneleiro & 90 \\
MM & Frota heterogênea: mix médio de mercado (carretas, bitrens. rodotrens) & 50 \\
AC & Frota antiga de carretas simples e trucadas & 20 \\
AT & Frota somente de veículos antigos e trucks & 0 \\
\hline
\end{tabular}

Tabela 05 - Construção da curva de valor para o atributo Adequação de frota.

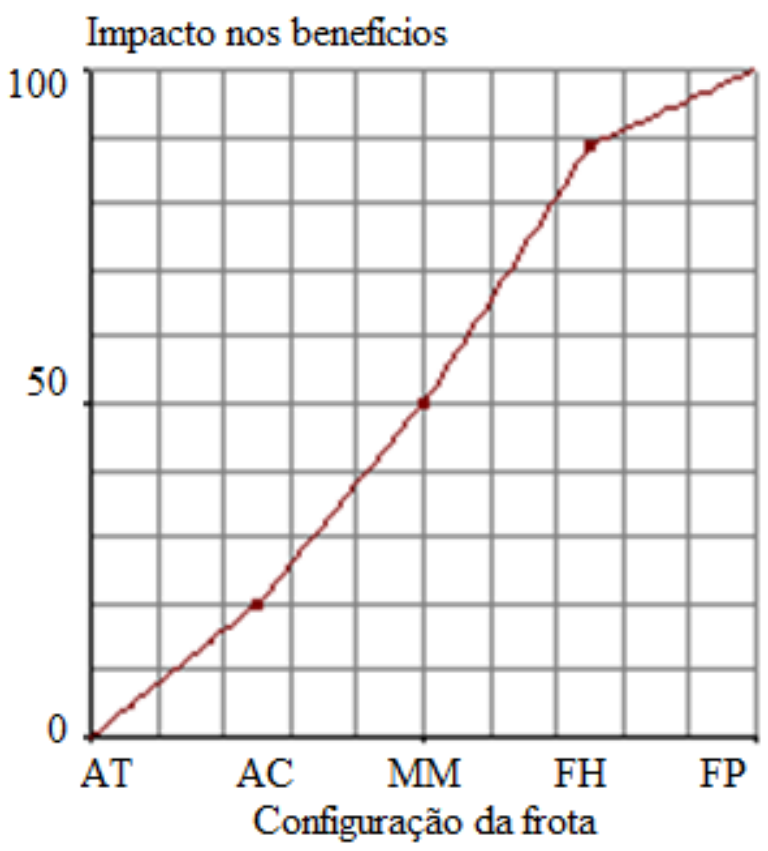

Figura 20 - Curva de valor para o atributo Adequação de frota. 
A Gestão e Controle é o terceiro atributo mais relevante e está apresentado na Figura 21. Na percepção do grupo, o desejável para a operação é uma informação em tempo real antes, durante e após o embarque, sendo esta condição favorável para que os embarques aconteçam sem grandes esforços, possuindo então a avaliação de 100. Caso seja necessário algum tipo de pressão por parte do embarcador, o impacto seria de 95 , ou seja, a informação seria obtida mediante solicitação e cobrança. Se o esforço tomado para a execução do embarque for muito grande (mediante solicitação, cobrança e sem resposta instantânea), a avaliação seria de 50 desde que houvesse retorno; caso o retorno não seja suficiente, o desempenho percebido seria de 45. Na ausência de informação, a avaliação seria 0 . A descrição deste atributo está disponível na Tabela 06.

Cód.

Gestão e controle

Impacto

atribuído

\begin{tabular}{ccc} 
IC & Informação completa antes, durante e depois do embarque & 100 \\
IS & Informação obtida mediante solicitação e cobrança & 95 \\
IA & Informação atrasada mediante solicitação e cobrança & 50 \\
SC & Informação atrasada e sem atendimento & 45 \\
SI & Sem informação disponível e sem atendimento & 0 \\
\hline
\end{tabular}

Tabela 06 - Construção da curva de valor para o atributo Gestão e controle.

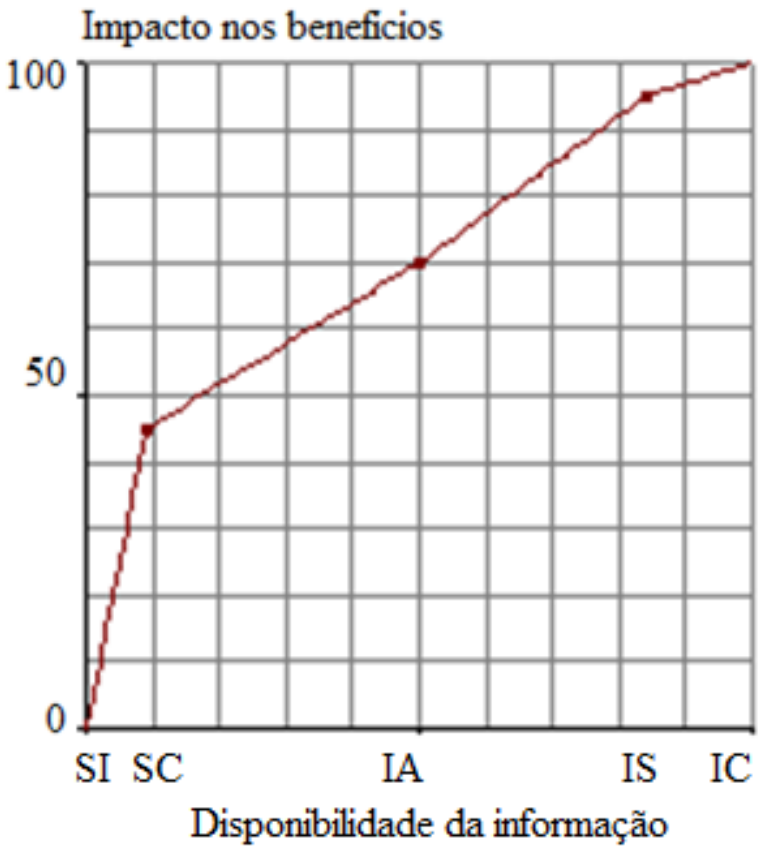

Figura 21 - Curva de valor para o atributo Gestão e controle.

Classificado como um atributo menos relevante, a Capacidade de inovação ilustrada na Figura 22 é percebida pelo embarcador como a plena utilização dos seus ativos 
(armazéns, fábricas e portos), em função da maneira e velocidade que os ativos de transporte são atualizados. Esse comportamento geraria uma preferência por alternativas de transporte que se atualizam mais rapidamente, gerando pleno uso dos ativos do embarcador. Na Tabela 07 está demonstrado como, na percepção do grupo, a Capacidade de inovação é fundamental para o pleno emprego do ativo da Trading.

\begin{tabular}{cc} 
Capacidade de inovação & $\begin{array}{c}\text { Impacto } \\
\text { atribuído }\end{array}$ \\
\hline $\begin{array}{c}\text { 100: a atualização é constante e permite o pleno uso do ativo do embarcador, } \\
\text { pois o transporte é mais eficiente, produtivo e competitivo }\end{array}$ & 100 \\
80: a inovação é pouco acima da média de mercado, pois existe o interesse \\
em oportunidades de desenvolvimento & 80 \\
50: média de inovação praticada pelo mercado & 50 \\
25: transporte se atualiza, mas com muitas limitações (ex. Transportadores & 10 \\
autônomos) & 0 \\
\hline
\end{tabular}

Tabela 07 - Construção da curva de valor para o atributo Capacidade de inovação.

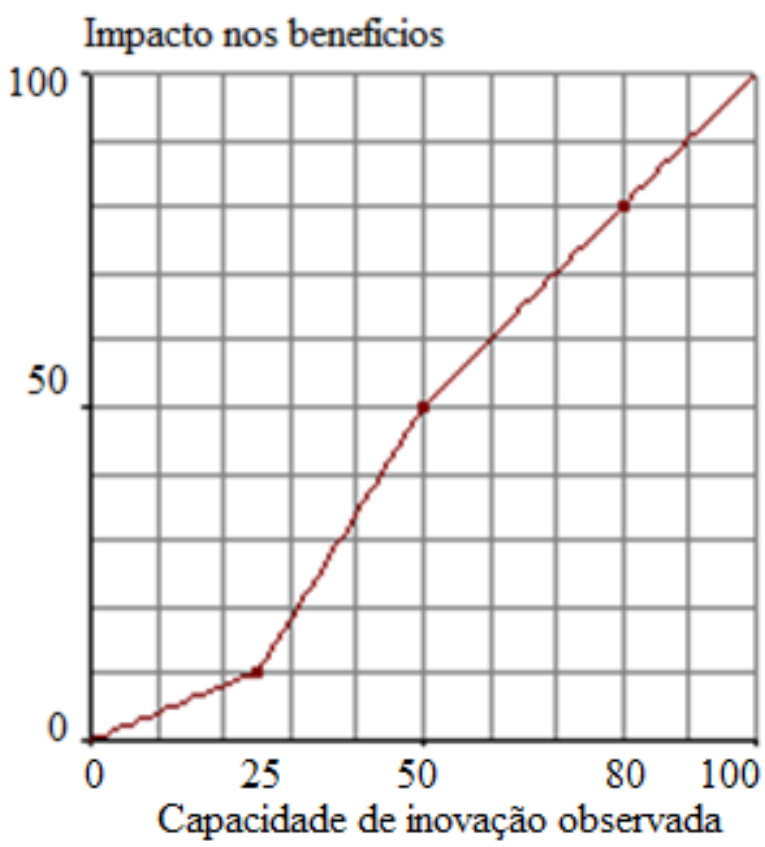

Figura 22 - Curva de valor para o atributo Capacidade de inovação.

Assim como a Capacidade de inovação, o Know-how adquirido mostrou-se de menor peso na qualificação dos Benefícios na opinião do grupo. Foram estabelecidos cinco cenários com diferentes níveis de inteligência competitiva absorvida pelo embarcador para classificar este atributo. A melhor avaliação aquela que fosse possível obter o completo conhecimento da operação, o que promoveria maior inteligência competitiva para a Trading. Ainda desejáveis estariam as alternativas que permitem antecipar-se ao 
mercado, ou seja, antecipar-se de alterações de frete, escassez de caminhões, entre outros. Quando não existisse vantagem competitiva, isto estaria associado ao pior desempenho observado. A Tabela 08 explicita como foi realizada esta avaliação e a curva de valor deste atributo exposta na Figura 23.

\begin{tabular}{ccc} 
Cenário & Itens de controle & $\begin{array}{c}\text { Impacto } \\
\text { atribuído }\end{array}$ \\
\hline A & Apenas faz cotações e contrata o frete, sem comparação com o mercado & 0 \\
B & Recebe informações do mercado de fretes sem conseguir antecipar-se & 60 \\
C & Consegue antecipar-se aos movimentos de frete & 80 \\
D & Conhecimento dos custos operacionais e dos movimentos de frete & 90 \\
E & Amplo conhecimento de custos, operação e mercado de fretes & 100 \\
\hline
\end{tabular}

Tabela 08 - Construção da curva de valor para o atributo Know-how adquirido.

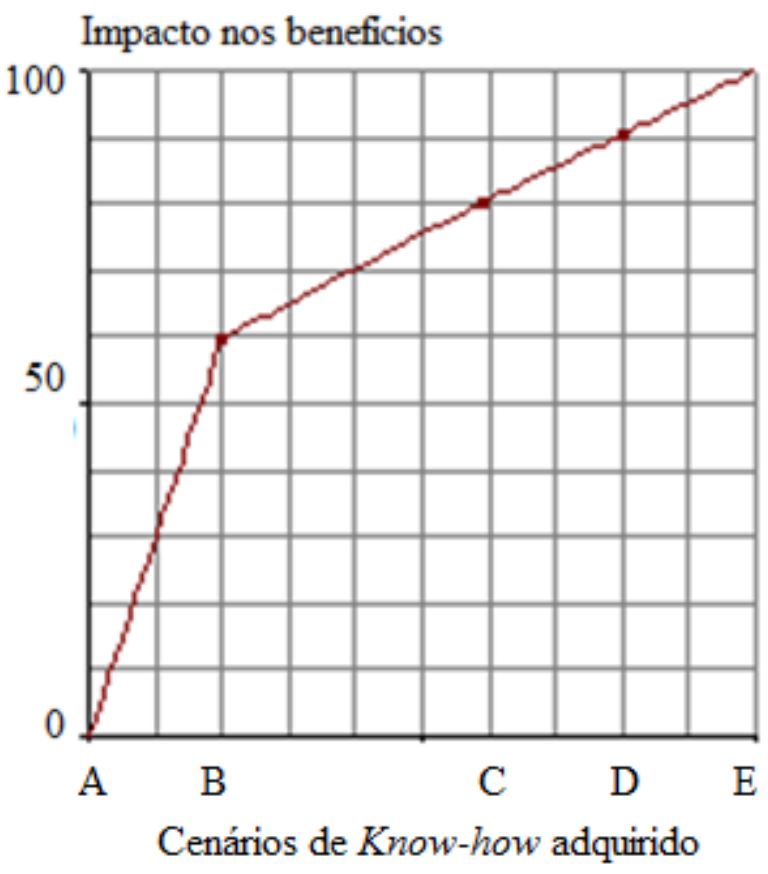

Figura 23 - Curva de valor para o atributo Know-how adquirido.

Estabelecidas as curvas de valor, serão avaliados os desempenhos de cada alternativa. Este processo foi realizado em uma segunda reunião com os gestores da Trading, que qualificaram cada alternativa segundo cada atributo. $\mathrm{O}$ resultado obtido desta avaliação está apresentado na Tabela 09. 


\begin{tabular}{ccccccc} 
Alternativa & $\begin{array}{c}\text { Atendimento } \\
\text { da demanda }\end{array}$ & $\begin{array}{c}\text { Adequação } \\
\text { de frota }\end{array}$ & $\begin{array}{c}\text { Gestão e } \\
\text { controle }\end{array}$ & $\begin{array}{c}\text { Capacidade } \\
\text { de inovação }\end{array}$ & $\begin{array}{c}\text { Know-how } \\
\text { adquirido }\end{array}$ & $\begin{array}{c}\text { Custo } \\
\text { total }\end{array}$ \\
\hline Verticalização & 100 & 100 & 100 & 100 & 100 & 0,97 \\
Parcial & 100 & 100 & 90 & 80 & 90 & 0,38 \\
Subcontratação & 90 & 50 & 70 & 50 & 60 & 0,00 \\
Contrato & 90 & 75 & 70 & 80 & 80 & 0,59 \\
Spot & 60 & 50 & 40 & 50 & 50 & 0,23 \\
\hline
\end{tabular}

Tabela 09 - Desempenho atribuído a cada estratégia.

\subsubsection{Avaliando as alternativas a partir das árvores de valores}

O uso da árvore de valores auxilia na interpretação do cálculo realizado pelo modelo. A estrutura apresentada na seção 4.2.3, construída na plataforma V.I.S.A,. foi capaz de avaliar os desempenhos de cada modelo de governança de acordo com as curvas de valor e pesos desenvolvidos durante a modelagem.

O resultado global da avaliação das alternativas foi a preferência pelo modelo de subcontratação, seguido pelas estratégias de e verticalização parcial e contratação spot. Afetadas pelo alto custo em relação às anteriores, o contrato e a verticalização total mostraram-se alternativas menos preferidas pelos tomadores de decisão. O desempenho de cada alternativa está apresentado na Figura 24.

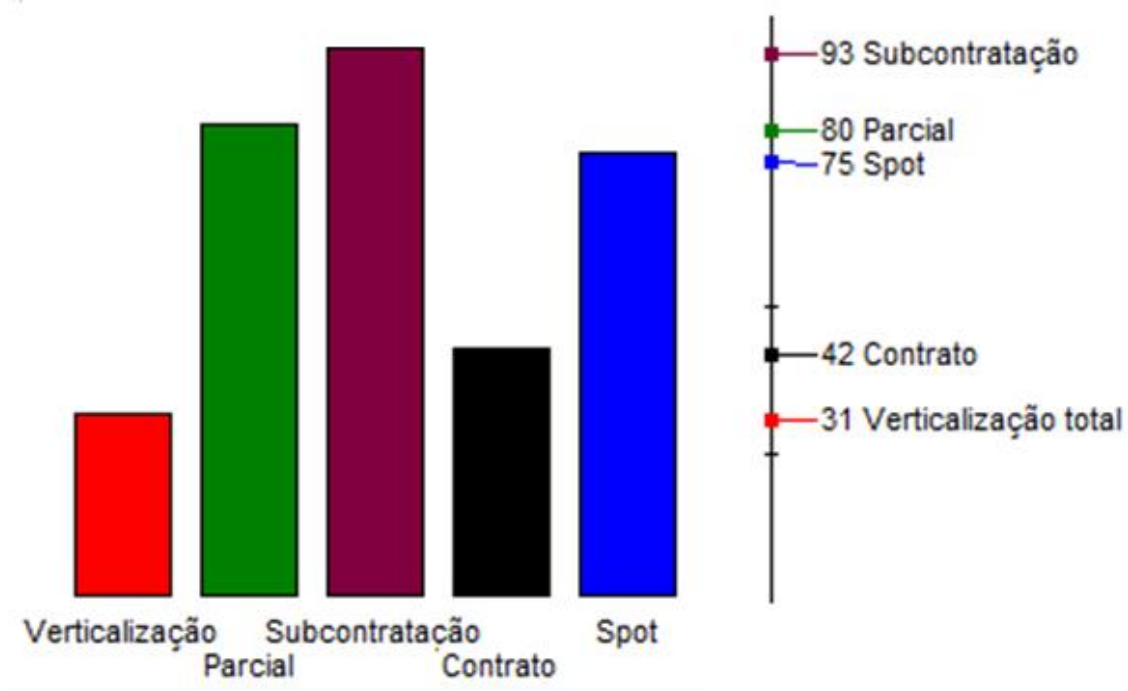

Figura 24 - Desempenho global das alternativas.

Ao olhar para o desempenho parcial de cada critério na Figura 25 pode-se perceber realmente que o Custo teve grande peso na decisão e inviabilizou a opção verticalizada e o contrato. A verticalização parcial mostrou-se ainda bem competitiva, pois teve um bom desempenho tanto em Custo como em Benefício. Apesar de ter uma percepção 
ruim quanto a Benefício, a estratégia spot apresentou um custo competitivo e como a subcontratação foi calculada baseada em um desconto da alternativa spot, ela foi a decisão com o melhor desempenho. Apesar de não existirem estudos concretos quanto aos impactos da Lei do Motorista, a Trading acredita que a fiscalização efetiva do cumprimento da lei irá aproximar os custos existentes entre os modelos de governança. Isso poderia favorecer e alterar significativamente os resultados.

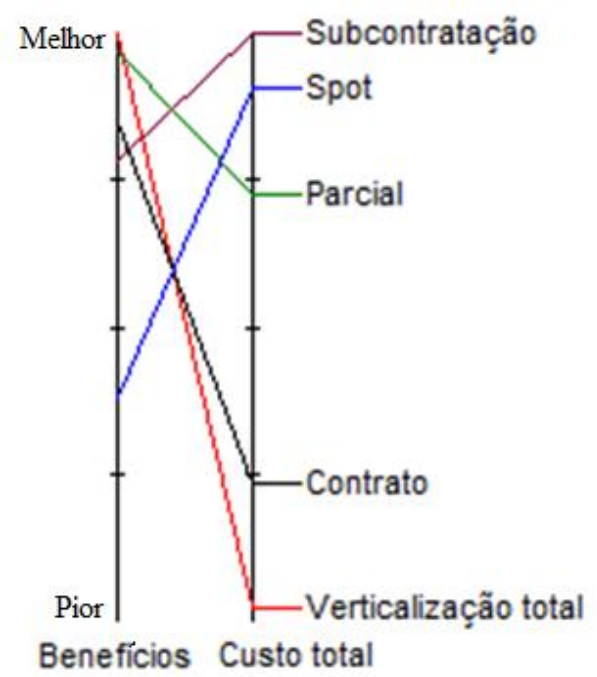

Figura 25 - Desempenho parcial dos subcritérios Custo e Benefício.

Uma outra visão do trade-off Custo x Benefício está apresentada na Figura 26, podendo-se perceber que a subcontratação apresenta um desempenho muito bom economicamente e qualitativamente. A alternativa de verticalização total neste estudo foi suprimida pela estratégia de verticalização parcial, subcontratação e contrato, uma vez que elas foram qualificadas com um desempenho bastante semelhante em relação à Benefício e Custos mais interessantes. 


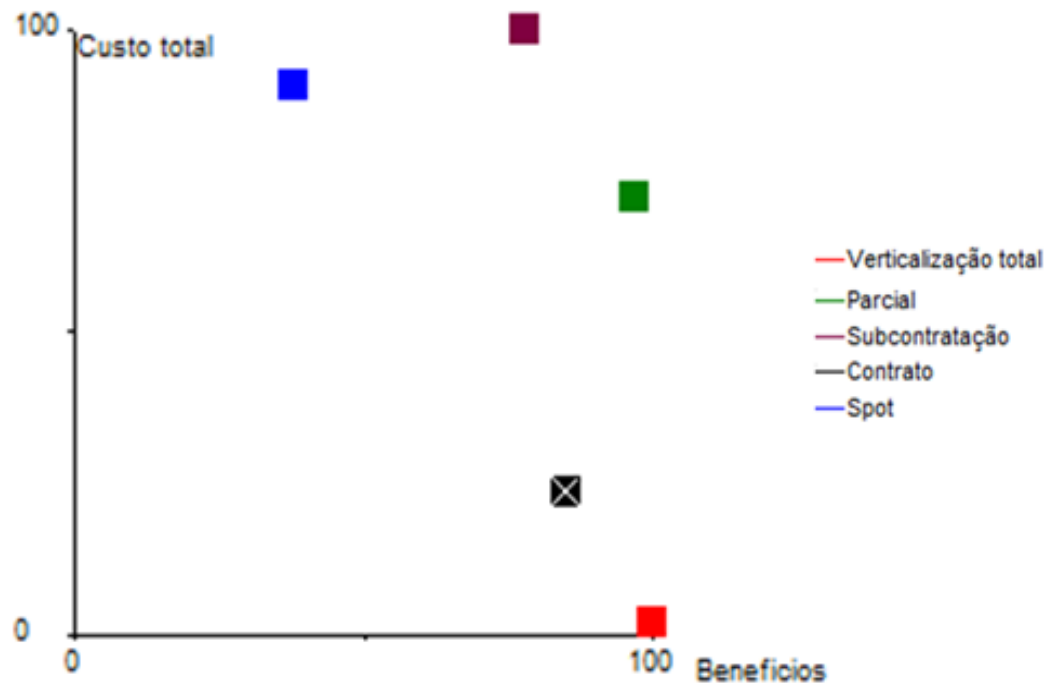

Figura 26 - Trade-off Custo x Benefício.

Na Figura 27 é possível observar o desempenho separado do subcritério Custo. Nota-se que o dado no gráfico foi trabalhado conforme detalhado na Tabela 10.

\begin{tabular}{|c|c|c|c|c|c|}
\hline Alternativa & $\begin{array}{l}\text { Frete ao porto } \\
\qquad(\mathrm{R} \$ / \mathrm{t})\end{array}$ & $\begin{array}{l}\text { Diferença } \\
\text { (R\$/t) }\end{array}$ & $\begin{array}{l}\text { Diferença } \\
\text { (R\$/saca) }\end{array}$ & $\begin{array}{c}\text { Valor pago ao } \\
\text { produtor }(\mathbf{R} \$ / \text { saca })\end{array}$ & Desempenho \\
\hline Verticalização & 143,90 & 16,20 & 0,97 & 49,03 & 3 \\
\hline Parcial & 134,10 & 6,40 & 0,38 & 49,62 & 62 \\
\hline Subcontratação & 127,70 & - & - & 50,00 & 100 \\
\hline Contrato & 137,60 & 9,90 & 0,59 & 49,41 & 41 \\
\hline Spot & 131,50 & 3,80 & 0,23 & 49,77 & 77 \\
\hline
\end{tabular}

Tabela 10 - Composição do desempenho para cada estratégia.

Como pior alternativa a verticalização total retornou um gasto com frete de $\mathrm{R} \$ 143,90 \mathrm{e}$ isso equivaleria a um desconto de quase $\mathrm{R} \$ 1,00 /$ saca de soja. Na curva de valor deste atributo, a capacidade de originação se limitaria bastante, obtendo um peso ponderado pela curva na ordem de 3 . Os resultados das demais alternativas estão dispostos na Figura 27. 


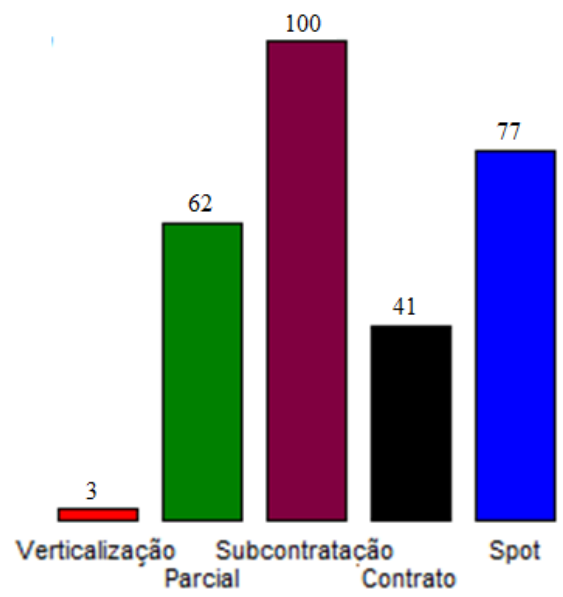

Figura 27 - Desempenho das estratégias para subcritério Custo.

Os Benefícios avaliados para cada estratégia foram capazes de indicar que a relação entre embarcador e transportador é mais importante do que parece. Quanto maior a proximidade entre as atividades, os gestores da Trading entenderam que melhores são os Benefícios observados. Mesmo quando há terceirização e a operação faz parte da negociação (estratégia de contratos de longo prazo), os Benefícios do compromisso assumido se refletem em uma satisfação melhor dos stakeholders. Na Figura 28 está apresentado o resultado parcial do subcritério benefícios.

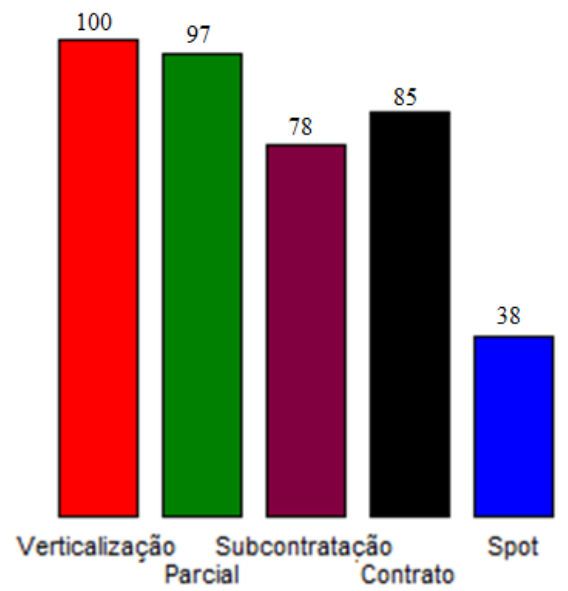

Figura 28 - Desempenho das estratégias para o subcritério Benefício.

Analisando separadamente os atributos do critério Benefício (Figura 29) pode-se observar que a estratégia spot e a subcontratação possuem um desempenho muito semelhante, exceto nos atributo gestão e know-how. A aproximação das atividades de transportador proporcionada pelos modelos verticalizados acaba sendo decisiva na qualidade do serviço prestado. Em outras palavras, à medida que o embarcador 
reconhece as necessidades do transportador compartilhando problemas e soluções, ele mesmo percebe os benefícios destas estratégias. Também é relevante pensar que o processo de confecção de um contrato mostra-se muito semelhante à verticalização, uma vez que há segurança entre as partes, compartilhamento de conhecimentos durante a negociação e $S L A$ 's que garantam a plena execução dos serviços.

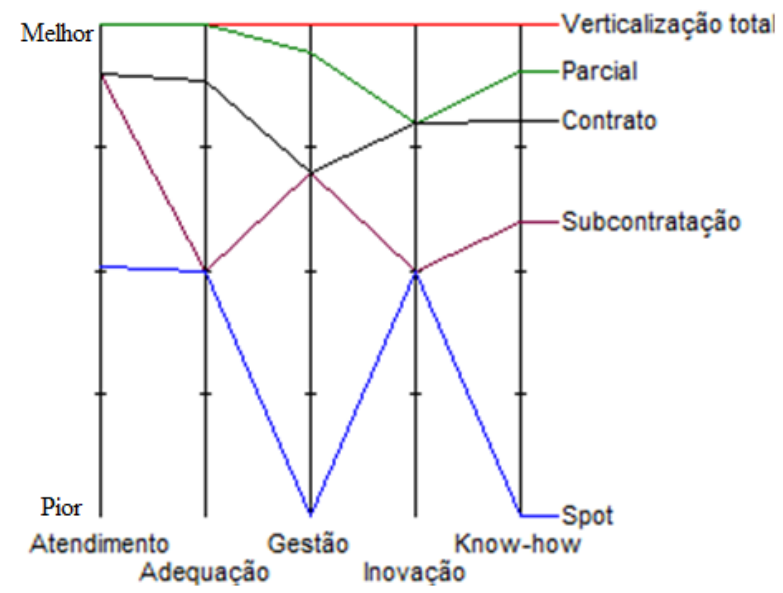

Figura 29 - Desempenho parcial para os atributos do subcritério Benefício.

Ao se comparar o desempenho para o critério Benefício em relação a cada atributo, nota-se na Figura 30 a confirmação de algumas premissas já apontadas. Há maior percepção de qualidade entre as alternativas coordenadas verticalmente e menor qualificação entre as estratégias de governança via mercado. Nesta avaliação destaca-se o empate existente entre verticalização total e parcial, mostrando que para a adequação de frota e atendimento da demanda, ambas as soluções foram as mais preferidas, sendo esse um dos motivos da verticalização total ser suprimida pela alternativa parcial. Retornando aos estudos de Williamson (1991), o fato da especificidade deste ativo ser igual para estes atributos assim como no desempenho parcial dos Benefícios, o fator determinante da escolha é realmente o custo, apresentado na Figura 31. A incerteza em relação ao ambiente também é um fator decisivo durante a escolha de um modelo de governança, e talvez tenha sido um dos motivos pela não escolha dos arranjos verticalizados. 


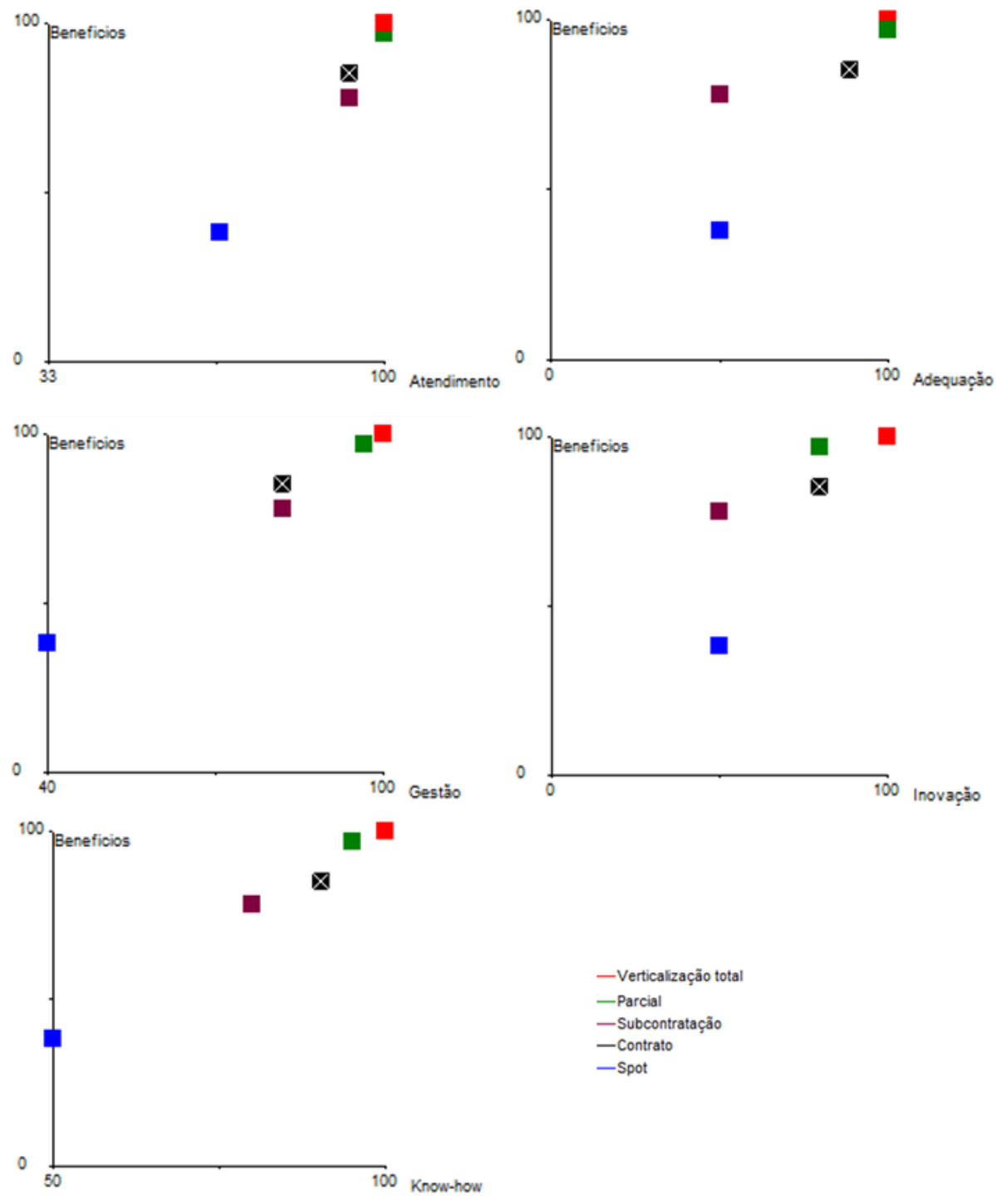

Figura 30 - Trade-offs da relação Benefício x Atributos.

Na Figura 31 é possível observar que a estratégia de subcontratar o transporte suprime outras estratégias nos atributos de Atendimento da demanda, Gestão e controle e Capacidade de inovação. Os desempenhos parciais em relação à Adequação de frota e Know-how adquirido tiveram as piores avaliações dado que a coordenação destes modelos é totalmente regida pelo mercado. Portanto, há uma variabilidade imensa do perfil dos ativos. 


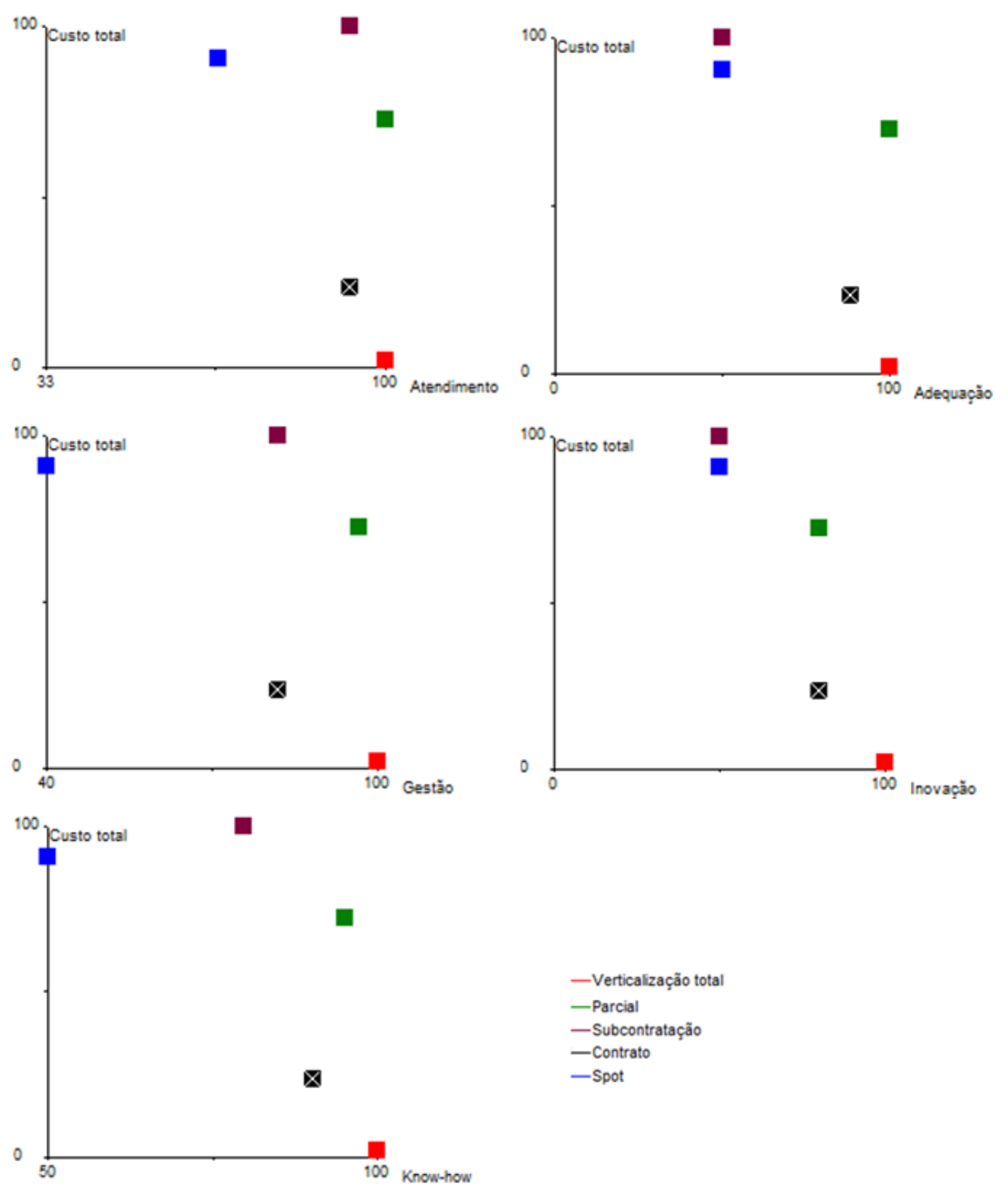

Figura 31 - Trade-offs da relação Custo x Atributos dos Benefícios.

De uma maneira geral, a análise realizada mostrou que existe uma polaridade entre as estratégias regidas voltadas ao mercado (e, portanto com menor custo) e as estratégias mais específicas às necessidades do embarcador e, nesse sentido, com melhor benefício percebido.

\subsubsection{Análise de sensibilidade}

Para entender melhor quais são os pontos de virada onde o modelo altera a decisão final, foi conduzida uma análise de sensibilidade para saber em qual relação Custo $\mathrm{x}$ Benefício haveria uma mudança de preferência do grupo em relação ao melhor arranjo estratégico. Na Figura 32 está apresentada uma análise de sensibilidade da escolha em 
relação ao critério Custo. Neste corte pode-se observar que a subcontratação é a alternativa preferida sempre que o Custo tiver um peso maior ou igual a $30 \%$ na opinião do decisor. Caso o Custo seja menos expressivo que isso, a estratégia preferida pela Trading seria a verticalização parcial, que teria a mesma preferência que a verticalização total quando o custo fosse zero. A verticalização total somente é a segunda colocada (acima da subcontratação e abaixo da parcial) quando o peso do custo for inferior a $14 \%$. A verticalização parcial é a segunda preferida quando o peso do custo for menor que $70 \%$. Caso o grupo atribua mais peso à decisão para este subcritério, então a contratação spot é a preferida. Entre 35 e $70 \%$ de peso atribuído ao custo, a estratégia spot é a terceira preferida, e abaixo disso esta alternativa é sempre a pior, uma vez que ela é a que observou o pior desempenho no subcritério de benefício. Já a decisão entre fazer um contrato de longo prazo ou verticalizar-se totalmente é favorável à verticalização caso o peso do custo seja inferior a $41 \%$. Acima deste percentual a verticalização é sempre a pior decisão na opinião do grupo entrevistado, uma vez que as demais foram preferidas.

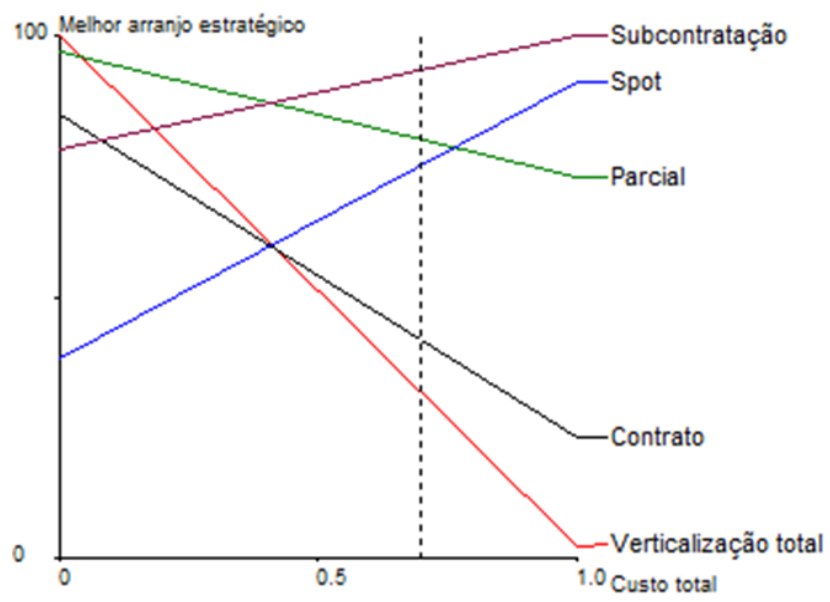

Figura 32 - Análise de sensibilidade da decisão em relação a Custo.

Na Figura 33 pode-se ver as mesmas curvas de decisão em relação ao critério Benefício. O resultado da análise é o mesmo apontado anteriormente, uma vez que os desempenhos não sofreram modificações. 


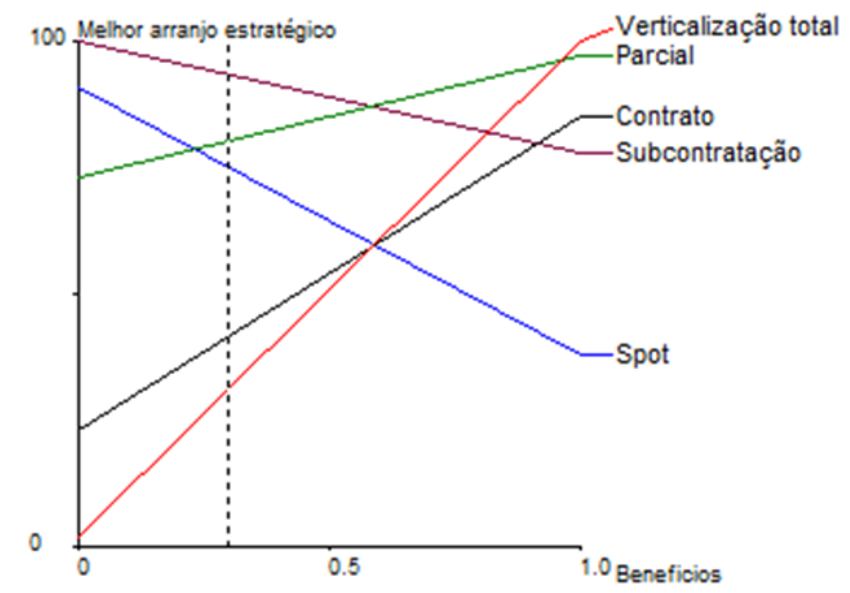

Figura 33 - Análise de sensibilidade da decisão em relação a Benefício.

Dada à preferência ao Custo pela Trading, foram realizadas simulações do desempenho das estratégias alterando o peso da relação Custo x Benefício. Imaginando que o Custo sempre vai ser uma variável importante, foi também comparada a diferença relativa entre as estratégias de subcontratação e verticalização (melhor e pior no modelo original respectivamente). No modelo original a diferença de Custo entre a subcontratação e a verticalização foi de $13 \%$; caso ela fosse de $2 \%$, ou seja, caso a opção de verticalização total fosse $2 \%$ mais cara que a subcontratação, ela seria a preferida por conta dos Benefícios observados.

A primeira variação considerada atribuiu pesos iguais (50/50) a Custo e Benefício e está estruturada na Figura 34. Nota-se nesta análise que há um desempate entre a verticalização parcial e a alternativa spot, com preferência pela alternativa verticalizada. As estratégias de contrato ou verticalização total possuem os piores desempenhos com estes pesos, sendo que a subcontratação perde pontos uma vez que há maior preferência por Benefícios. O resultado desta simulação está apresentado na Figura 35. Para que a verticalização fosse preferida em relação à subcontratação, neste cenário, a verticalização precisaria ter um custo de no máximo 3,5\% superior ao custo da subcontratação. 


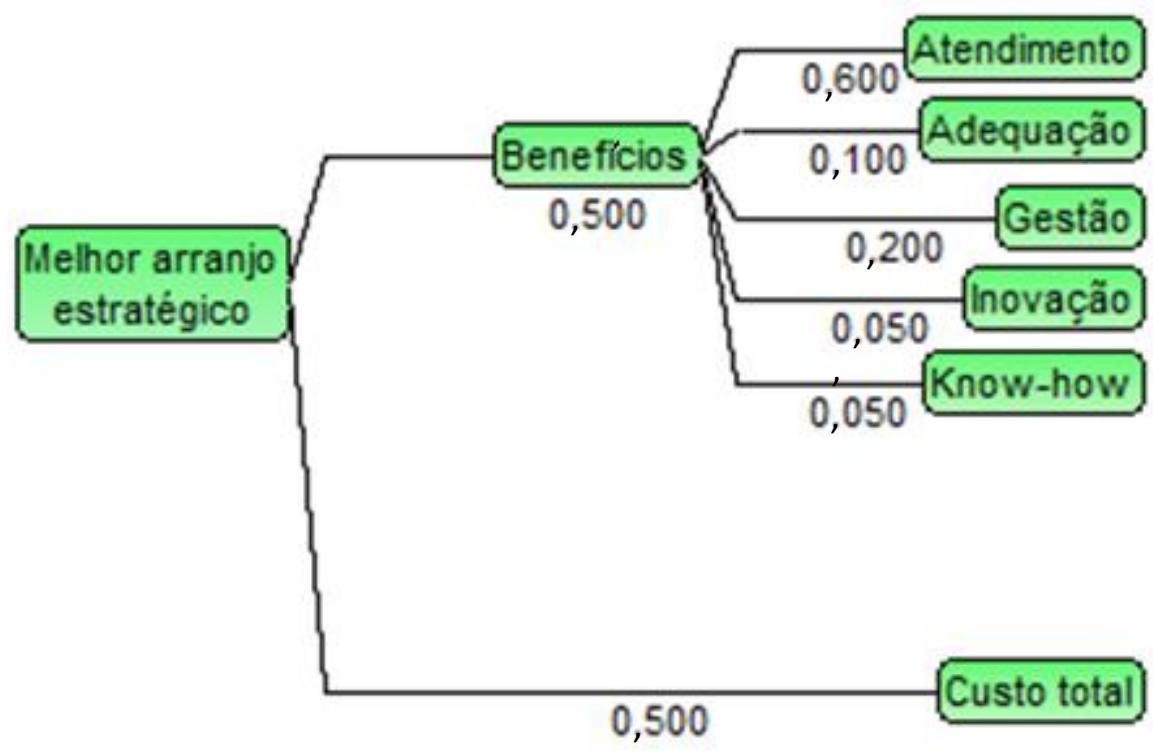

Figura 34 - Árvore de valores da primeira variação.

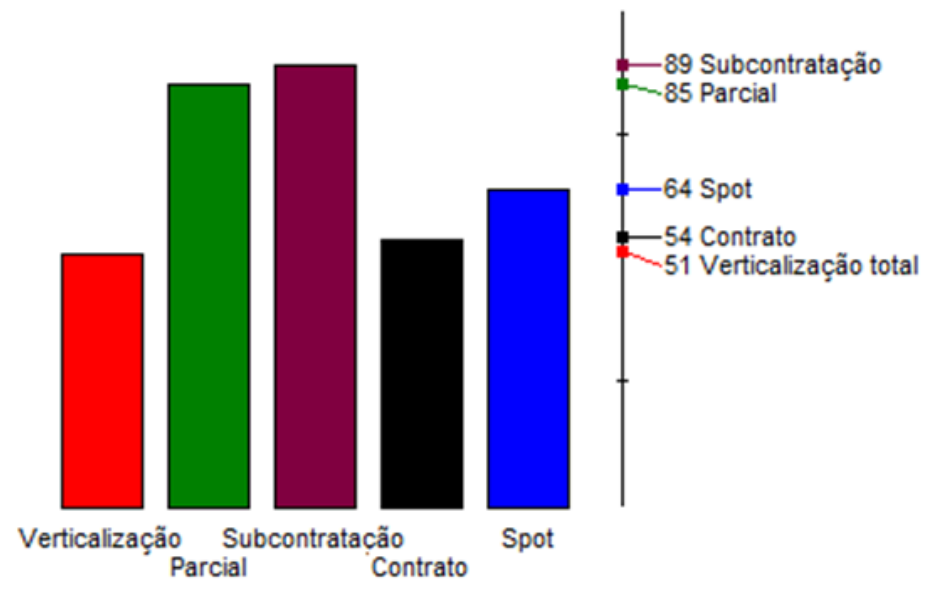

Figura 35 - Desempenho global da primeira variação.

A segunda simulação realizada envolveu a inversão da preferência inicial, ou seja, atribuiu-se $30 \%$ de peso ao Custo e $70 \%$ ao Benefício (Figura 36). Este modelo mostrou um empate técnico entre as estratégias de subcontratação e verticalização parcial. Na Figura 37 nota-se o empate ainda existente entre verticalização total ou terceirização via contratos, e a alternativa spot foi a menos preferida. A diferença máxima de custo permitida entre a verticalização total e a subcontratação foi de $5 \%$, ou seja, neste ponto teríamos um ponto de virada na preferência dos entrevistados da Trading. 


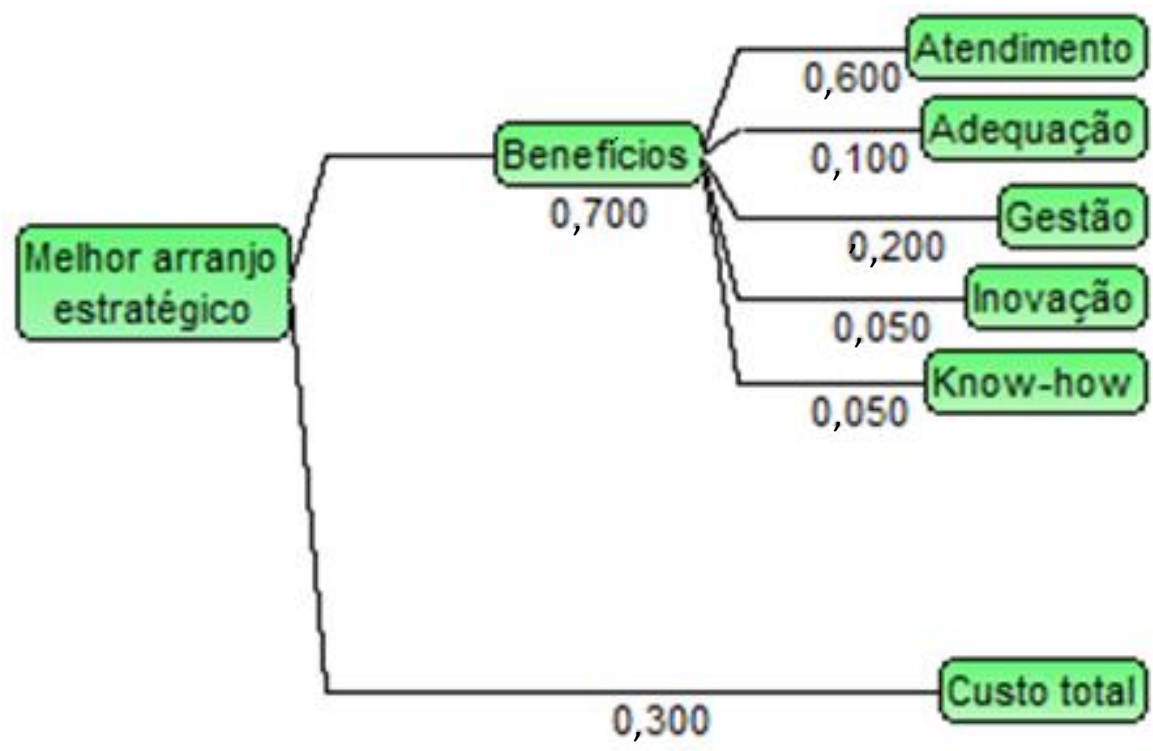

Figura 36 - Árvore de valores da segunda variação.

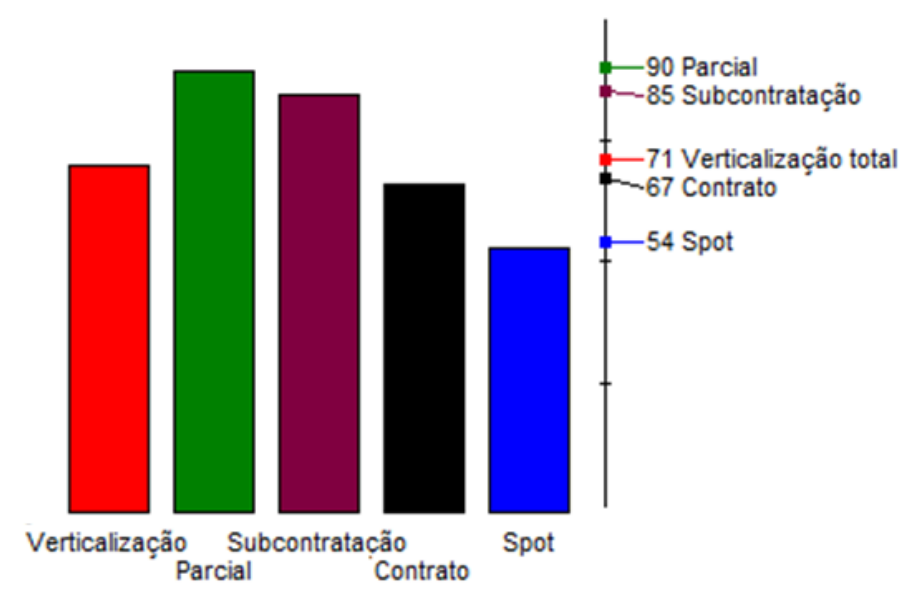

Figura 37 - Desempenho global da segunda variação.

O uso da análise de sensibilidade mostrou-se bastante importante para identificar os pontos de virada, onde os decisores mudam de preferência. Isso significa que à medida que o desempenho de cada alternativa muda, a decisão também pode mudar. Baseado nos critérios de Custo e Benefício, este modelo pode ser aplicado em situações onde o nível de serviço seja mais perceptível bem como em ambientes onde o custo possui comportamentos diferentes. Considerando que a diferença entre a verticalização total e o frete da subcontratação foi de apenas $13 \%$, caso o frete permaneça subindo acima da inflação em virtude da demanda por cargas, a opção da verticalização se tornaria mais atrativa a cada ano. 
Analogamente e utilizando a comparação entre a verticalização parcial e a subcontratação, a estratégia parcial torna-se mais interessante quando o Benefício observado for de 40\%. Portanto, assim como é observado em países mais desenvolvidos, a governança híbrida é bastante observada, principalmente para bens de consumo. Mercados mais commoditizados como os granéis sólidos agrícolas possuem poucas soluções logísticas considerando este tipo de integração, mas certamente é uma alternativa potencial de uso quando o Benefício tiver maior relevância.

A aplicação do modelo na Trading foi de extrema significância tanto para o teste da metodologia bem como do modelo criado. A participação dos stakeholders foi extremamente importante, não apenas pelo poder de decisão envolvido, mas também para o desenvolvimento dos critérios e atributos. Apesar da subjetividade que uma análise qualitativa pode trazer, o uso de um modelo multicritérios auxilia as avaliações, pois é possível aliar as preferências através de curvas específicas de valor. 


\section{CONCLUSÕES}

O uso da teoria da Economia dos Custos de Transação aliado à análise multicritério (MCDA) mostrou-se neste trabalho uma combinação interessante para a avaliação de arranjos competitivos. O estudo se utilizou de árvores de valores para classificar estratégias de governança, comparando-as no que tange aos seus Custos e Benefícios. Além disso, o estudo realizou uma extensa revisão bibliográfica e um diagnóstico das estruturas presentes nas empresas embarcadoras de granéis sólidos agrícolas, o que serviu de base para o desfecho desta dissertação.

Entre os modelos observados de coordenação vertical, considera-se: i. Integração vertical total com aquisição e operação de ativos; ii. Integração vertical parcial com aquisição de ativos e operação por terceiros; iii. Integração vertical parcial sem ativos, mas subcontratando o transporte de terceiros; iv. Terceirização total, com presença de contratos de longo prazo; v. Terceirização total sem presença de contratos (spot).

Estas estratégias são utilizadas pelas empresas embarcadoras e o que as diferencia podem ser as características do mercado, tipos distintos de operação, custos, entre outros. A situação regulatória que o transporte rodoviário está passando sinaliza que o modelo dominante deverá sofrer alterações e, dependendo do cenário futuro, irá favorecer uma estrutura mais ou menos verticalizada.

Aspectos contidos na teoria da Economia dos Custos de Transação sugerem que em ambientes com menor incerteza e maior especificidade dos ativos, existe uma tendência de se encontrar estruturas verticais. Esta teoria também pode ser aplicada no transporte rodoviário de cargas e está alinhada com os resultados obtidos pelo modelo desenvolvido neste trabalho.

O modelo desenvolvido e aplicado através de um estudo de caso em uma grande embarcadora mostrou que a um nível de preferência de $70 \%$ de custo em relação a benefício, a estratégia de verticalização parcial através de subcontratação de terceiros teve o melhor desempenho (93). A verticalização total apresentou um custo de $13 \%$ superior à vencedora e, por esta razão, foi a estratégia menos preferida no cenário proposto com desempenho de apenas 31 na opinião do grupo que participou do estudo de caso. Soluções intermediárias como a verticalização parcial com ativos operados por 
terceiros mostrou-se a preferida quando o benefício tivesse maior peso na decisão, além disso, foi a segunda classificada no estudo de caso.

O método desenvolvido mostrou-se capaz de lidar com os principais objetivos, critérios e variáveis encontrados nas decisões sobre verticalização. Apesar das curvas de valor e avaliação das alternativas terem sido desenvolvidas para uma situação específica, o modelo proposto pode ser aplicado em situações semelhantes com curvas de valores ajustadas à necessidade de cada embarcador. As análises apresentadas reforçam que decisões, ainda que subjetivas, podem ser quantificadas. Dificilmente seria possível chegar a tal resultado através de uma planilha de custo e, nesse sentido, ao se utilizar dados qualitativos somados à abordagem multicritério, o resultado obtido pode ser visualizado de maneira mais clara.

Apesar de o referencial teórico de ECT e MCDA ser amplamente difundido, este tipo de análise costuma ser estudada através de análises estatísticas e da quantificação numérica dos atributos, respectivamente. Todavia, o modelo desenvolvido considerou essencialmente as opiniões de um grupo de gestores de logística agroindustrial aplicadas a um estudo de caso específico e conseguiu trazer um resultado satisfatório. Efetivamente seria mais adequado se a modelagem considerasse somente atributos exatos como o custo, por exemplo. Entretanto, a criação de curvas de valores e avaliação baseadas em valor auxiliam os tomadores de decisão a quantificarem as preferências, ainda que de maneira subjetiva. Além disso, a abordagem multicritério permite a análise gráfica e uma melhor comparação entre os trade-offs existentes.

O desenvolvimento descritivo do transporte rodoviário de granéis agrícolas na atualidade é um ponto de partida para um estudo profundo das mudanças que virão com a regulamentação do setor. As organizações que estão inseridas neste meio precisarão de trabalhos que auxiliem o melhor desenho competitivo para que os investimentos não deixem de ser realizados e que contribuam para a evolução deste segmento tão importante para a economia brasileira.

Quanto à recomendação para trabalhos futuros, sugere-se a montagem de novos estudos de caso considerando ambientes e situações diferentes, de modo que se possa explorar todas estas alternativas. Esta pesquisa poderia expandir fronteiras e comparar o transporte rodoviário em diversos países ou até mesmo em diversas regiões do Brasil, 
para então aplicar este modelo em ambientes mais ou menos regulados. As variações possíveis do modelo apresentado mostraram que o custo muda significativamente o resultado. Talvez, neste sentido, também seja uma oportunidade interessante o desenvolvimento de novas alternativas visando à minimização de custos para completar esta linha de pesquisa. 


\section{REFERÊNCIAS BIBLIOGRÁFICAS}

ALL, América Latina Logística - Relatório Trimestral para Investidores. Disponível em: <http://www.all-logistica.com.br>. Acesso em: 01 dez. 2013.

ALMEIDA, A.T. O Conhecimento e o uso de métodos multicritério de apoio a decisão. 2 ed. Recife: Editora Universitária da UFPE, 2011. 234 p.

ANEC, Associação Nacional dos Exportadores de Cereais. Disponível em: <http://www.anec.org.br>. Acesso em: 01 ago. 2013.

ANFAVEA, Associação Nacional dos Fabricantes de Veículos Automotores. Disponível em <http://www.anfavea.org.br/cartaanfavea>. Acesso em: 18 jul. 2013.

ANFIR, Associação Nacional dos Fabricantes de Implementos Rodoviários. Disponível em <http://www.anfir.org.br/estatisticas>. Acesso em: 18 jul. 2013.

ANTAQ, Agência Nacional dos Transportes Aquaviários. Disponível em: <http://www.antaq.gov.br>. Acesso em: 01 mar. 2013.

ANTT, Agência Nacional dos Transportes Terrestres. Resoluções diversas. Disponível em: 〈http://www.antt.gov.br〉. Acesso em: 01 mar. 2013.

ARAÚJO, M.P., MARTINS, R.S. Transporte de Cargas Frigorificadas na Indústria Avícola: Evidências para uma Interpretação à Luz da Teoria dos Custos de Transação. IV Congresso Internacional de Economia e Gestão de Redes Agroalimentares. FEA/USP - Campus Ribeirão Preto, 2003.

AZEVEDO, P.F. Nova economia institucional: referencial geral e aplicações para a agricultura. Agricultura São Paulo, São Paulo, v. 47, n.1, 2000. p. 35-52.

AZZAM, A.M. Competition in the US meatpacking industry: is it history?. Agricultural economics, Elsevier, 1997. p. 107.126.

BARAT, J. Transportes e Industrialização no Brasil no período 1885-1985. Rio de Janeiro: Biblioteca do Exército, v.279, 1991. p. 107-127. 
BARROS, P., RAMOS, F. Análise do jogo de barganha no setor de contratação de uma empresa de transporte. Encontro Nacional de Engenharia de Produção. Porto Alegre, 2005. p. 3053-3060.

BARTHOLOMEU, D.B., PERA, T.G., CAIXETA-FILHO, J.V. Avaliação de impactos ambientais decorrentes da redução do consumo de combustível no transporte rodoviário de cargas. Piracicaba, Revista Economia e Sociologia Rural, v. 46, 2008.

BAZERMAN, M., MOORE, D. Processo decisório. $7^{\text {a }}$ Edição. Rio de Janeiro: Elsevier, 2010

BELTON, V., STEWART, T.J. Multiple criteria decision analysis: an integrated approach. Boston : Kluwer Academic Publishers, 2002. 372 p.BNDES, Banco Nacional do Desenvolvimento, Disponível em: <http://www.bndes.gov.br>. Acesso em: 01 ago. 2013.

BORGES, B.G. O despertar dos dormentes. In: A era Ferroviária, Goiânia, CegrafUFG, 1990. p.1-50.

BRANCO, J.E.H. Estimativa de demanda de carga captável pela Estrada de Ferro Norte-Sul. Dissertação (Mestrado) - Escola Superior de Agricultura 'Luiz de Queiroz', Universidade de São Paulo, Piracicaba, 2007.

BRIOZO, R., LORETI, J., ROSA, M., MARINHO, E., CAIXETA-FILHO, J.V. Implantação de uma empresa de transportes de cargas agrícolas no município de Piracicaba. Revista ANTT, v3, maio, 2011.

CAIXETA FILHO, J.V. Pesquisa Operacional. São Paulo. Atlas, 2004. p. 95.

CAIXETA-FILHO, J.V., GAMEIRO, A.H. Administração de seguros no transporte de cargas. ERA-eletrônica. São Paulo, V1, jan-jun, 2002.

CAIXETA FILHO, J.V., GAMEIRO, A. H. Transporte e logística em sistemas agroindustriais. São Paulo. Atlas, 2001. p. 218.

CAIXETA FILHO, J.V., MARTINS, R. S. Gestão logística do transporte de cargas. São Paulo. Atlas, 2001. p. 296. 
COASE, R. H. The Nature of the Firm. Economics, New Series, Vol. 4, No. 16. 1937, p. 386-405. Disponível em: <http://links.jstor.org/sici?sici=00130427\%28193711\%292\%3A4\%3A16\%3C386\%3ATNOTF\%3E2.0.CO\%3B2-B>. Acesso em: 01 set. 2012.

CONAB - Companhia Nacional de Abastecimento. Disponível em <http://www.conab.gov.br/index.php>. Acesso em: 15 ago. 2013.

CORREIA JUNIOR, G. Determinantes do preço do frete rodoviário para transporte de soja em grãos em diferentes regiões brasileiras: uma análise econométrica. Dissertação (Mestrado) - Escola Superior de Agricultura 'Luiz de Queiroz', Universidade de São Paulo, Piracicaba, 2001.

DE BOER, L., LABRO, E., MORLACCHI, P. A review of methods supporting supplier selection. European Journal of Purchasing and Supply Management, 2001. p. 75-89.

DE BOER, L., WEGEN, L. Practice and promise of formal supplier selection: a study of four empirical cases. European Journal of Purchasing and Supply Management, 2003. p. 109-118.

EASTMAN, S.E. Selected productivity comparisons in surface freight transportation: inland water, rail, and truck, 1955-1979. Transportation Research Record, v.880, 1982. p.22-26.

EISENHARDT, K.M. Building theories from case study research. Academy of Management. The Academy of Management Review, 1989. p. 532.

EISENHARDT, K.M., ZBARACKI, M.J. Strategic decision making. Strategic Management Journal, 13, 1992. p. 17-37.

EPL, Empresa de Planejamento Logístico. Disponível em <http://www.epl.gov.br/index.php>. Acesso em: 10 ago. 2013.

ESALQ-LOG - Grupo de Pesquisa e Extensão em Logística Agroindustrial. Disponível em: <http://log.esalq.usp.br>. Acesso em: 20 jul. 2013. 
FARINA. E., AZEVEDO, P., SAES, M. Competitividade: mercado estado e organizações. São Paulo. Ed. Singular, 1997. p. 285.

FERNANDEZ, M. Avaliação da utilização de documentos fiscais eletrônicos na rastreabilidade de cargas. Dissertação (Mestrado) - Escola Politécnica, Universidade de São Paulo, São Paulo, 2012.

FRANCO, L.A., MONTIBELLER, G. Decision and risk analysis for the evaluation of strategic options. In: O'Brien FA and Dyson RG (eds.) Supporting Strategy: Frameworks, Methods and Models. Chichester: Wiley, 2007, pp. 251-284.

FRANCO, A., MONTIBELlER, G. Invited Review - Facilitated Modelling in Operational Research. European Journal of Operational Research Vol 205, No. 3, 2010. p. 489-500.

FRANCO, L.A., MONTIBELlER, G. Problem structuring for multi-criteria decision analysis interventions. In: Cochran JJ, Cox Jr LA, Keskinocak P, Kharoufeh JP and Smith JC (eds). Wiley Encyclopedia of Operations Research and Management Science.Wiley: New York, 2011.

FRANCO, L.A., MONTIBELlER, G. Raising the Bar: Strategic Multi-criteria Decision Analysis. Journal of the Operational Research Society, 2011, 62 (5): 855-867.

GALVÃO, O. Desenvolvimento dos Transportes e Integração Regional no Brasil Uma Integração Histórica. Planejamento e Políticas Públicas PPP, n.13, jun, 1996. p. 184-211.

GAMEIRO, A.H. Índices de preço para o transporte de cargas: o caso da soja a granel. Dissertação (Mestrado) - Escola Superior de Agricultura 'Luiz de Queiroz', Universidade de São Paulo, São Paulo, 2003.

GEIPOT - Empresa Brasileira de Planejamento de Transportes. Corredores estratégicos de Desenvolvimento. Alternativas para escoamento de soja para exportação. Brasília, GEIPOT, 2001.

GOODWIN, P., WRIGHT, G. Decision Analysis for Management Judgment. 3ed. Chichester: John Wiley \& Sons, 2004. 477 p. 
GOVERNO FEDERAL, Lei 10.209/01, Disponível em: <http://www.planalto.gov.br/ccivil_03/leis/leis_2001/L10209.htm>. Acesso em: 01 fev. 2013.

GOVERNO FEDERAL, Lei 11.442/2007, Disponível em: <http://www.planalto.gov.br/ccivil_03/_Ato2011-2014/2012/Lei/L12619.htm>. Acesso em: 01 fev. 2013.

GOVERNO FEDERAL, Lei 12.619/2012, Disponível em: <http://www.planalto.gov.br/ccivil_03/_ato2007-2010/2007/lei/111442.htm>. Acesso em: 01. mai. 2013.

HAMMOND, J.S., KEENEY, R.L., RAIFFA, H. Smart Decisions. Harvard Business School Press, Boston, 1998.

HAN, C., CORSI., T, GRIMM, C. Why do carriers use owner operators in the U.S. for hire trucking Industry? Transportation Journal, 2008. p. 22-35.

HEINRICH, J. Aplicação da análise de riscos a atividades do transporte rodoviário de cargas. Dissertação (Mestrado) - Arquitetura e Urbanismo, Universidade Estadual de Campinas, São Paulo, 2000.

HILLIER, F., LIEBERMAN, G.H. Introdução à pesquisa operacional. Mc Graw Hill, $8^{\mathrm{a}}$ ed. São Paulo, 2006.

HO, W., XU, X., DEY, P. Multi-criteria decision making approaches for supplier evaluation and selection - A literature review, European Journal of Operational Research. 202, 2010. p. 16-24.

ILOS, Instituto de Logística e Supply Chain, Valor Setorial: Logística - Ajuste estratégico. São Paulo, 2013.

KEENEY, R.L. Decision Analysis: An Overview. Operations Research, Vol. 30, No. 5, 1982. p. 803-838.

LIMA, M.P. O Custeio do Transporte Rodoviário. 2005. Disponível em < www.coppead.com.br>, acessado em 03/05/2014. 
MACHADO, R. Rastreabilidade, tecnologia da informação e coordenação de sistemas agroindustriais. Tese (Doutorado) - Faculdade de Economia, Administração e Contabilidade, Universidade de São Paulo, São Paulo, 2000.

MARQUES, S.A. Privatização do Sistema Ferroviário Brasileiro, Brasília: IPEA, 1996. p. 67.

MARTINS, R.S. Estudo da formação do frete rodoviário e potencial de conflitos em negociações em cadeias do agronegócio brasileiro. Organizações Rurais e Agroindustriais, v. 10, 2008. p. 75-89.

MARTINS, R.S., LOBO, D., SALVADOR, E., PEREIRA, S. Características do mercado de fretes rodoviário para produtos do agronegócio nos corredores de exportação do centro-sul brasileiro. Teoria e Evidência Econômica, Passo Fundo, v.12, n.22, mai. 2004. p. 35-50.

MASON, R., LAWANI, C., BOUGHTON, R. Combining vertical and horizontal collaboration for transport optimization. Emerald, Supply Chain Management: An International Journal, 2007. p. 187-199.

MCNAMEE, P. CELONA, J. Decision analysis for the professional. 4th Edition, SmartOrg, 2007.

MONTIBELlER, G., YOSHIZAKI, H. A Framework for Locating Logistic Facilities with Multi-Criteria Decision Analysis. In Evolutionary Multi-Criterion Optimization, edited by Ricardo Takahashi et al., 6576:505-519. Lecture Notes in Computer Science. Springer Berlin / Heidelberg, 2011.

NEVES, M.F. Um Modelo para o Planejamento de Canais de Distribuição. Tese (Doutorado) - Faculdade de Economia, Administração e Contabilidade, Universidade de São Paulo, Brasil, 1999. p. 297.

NEVES, M.F., ZUURBIER, P., CAMPOMAR, M.C. A Model for the Distribution Channels Planning Process. Journal of Business \& Industrial Marketing. Vol 16, Number 6 and 7, MCB University Press. Florida , USA . ISSN 0885-8624, 2001. p.518539. 
NORTH, D.C. Institutions, and economics theory. American Economist, Los Angeles, v.36, n.1, 1992. p. 3-6.

NTC - Associação Nacional do Transporte de Cargas e Logística. Disponível em: <http://www.ntc.org.br>. Acesso em: 20 jun. 2014.

NUNES, I. Integração Ferroviária Sul-Americana. São Paulo, Annablume, 2011.

OLIVEIRA, C.F. ROSA, M.J., CAIXETA FILHO, J.V. Estimativa da oferta de fertilizantes como carga de retorno no ambiente portuário brasileiro entre 2005 e 2009. Informações Econômicas, SP, v. 40, n. 9, set. 2010. p. 45-53.

OLIVEIRA, J.C. Análise do Transporte de Soja, Milho e Farelo de Soja na Hidrovia Tietê-Paraná. Dissertação (Mestrado) - Escola Superior de Agricultura "Luiz de Queiroz", Universidade de São Paulo. Piracicaba, 1996.

PAC, Programa de aceleração do crescimento. <http://www.pac.gov.br/index.php>. Acesso em: 01 ago. 2013.

PADOVANI, M., MUSCAT, A., CAMANHO, R., CARVALHO, M. Looking for the right criteria to define projects portfolio: Multiple case study analysis. Managementr \& Development, vol. 6, n. 2, 2008. p. 134.

PARNELl, G., DRISCOLL, P., HENDERSON, D. Decision making in systems engineering and management. Series In: Systems Engineering and Management, 2008 .

PASSARINI, A. O Setor de Transporte no Brasil: Um Estudo Comparativo. USPFEA, Resumo IV SemeAd, out. 1999. p. 12.

PEIXOTO, J.B. Os Transportes no Atual Desenvolvimento do Brasil. Rio de Janeiro: Biblioteca do Exército, v.147, 1977. p.15-19.

PERRUPATO, M. PNLT - Plano Nacional de Logística e Transportes. Disponível em: < http://www.transportes.gov.br/conteudo/36391>. Acesso em: 10 mar. 2012.

PRADO, A. Análise multicritério aplicada na seleção de fornecedores de logística. Dissertação (Mestrado) - Escola Politécnica, Universidade de São Paulo, São Paulo, 2011. 
RIBEIRO, B. Coordenação vertical no transporte de madeira: análise empírica das estruturas organizacionais existentes. Dissertação (Mestrado) - Escola Superior de Agricultura "Luiz de Queiroz", Universidade de São Paulo. Piracicaba, 1997.

RIBEIRO, B.M., CAIXETA FILHO, J.V. Coordenação vertical do transporte de madeira: análise empírica dos arranjos institucionais existentes na indústria brasileira de celulose. Gestão \& Produção. Vol. 7(1), abr. 2000. p. 1-16.

ROCHA, F.V., TROMBETA, N.C., BARTHOLOMEU, D.B., PERA, T.G., CAIXETAFILHO, J.V. Avaliação dos ganhos logísticos com a utilização da armazenagem entre os anos de 2009 e 2011. 50 Congresso da Sociedade Brasileira de Economia, Administração e Sociologia Rural. Anais do congresso. Vitória, 2012.

RODOCRED, Informativo Dbtrans. Disponível em: <http://www.rodocred.com.br>. Acesso em: 01 dez. 2013.

RODRIGUES, L. O processo de terceirização e a presença de arranjos institucionais distintos na colheita de cana-de-açúcar. Dissertação (Mestrado) Escola Superior de Agricultura "Luiz de Queiroz", Universidade de São Paulo. Piracicaba, 2006.

ROY, B. Robustness in operational research and decision aiding: A multi-faceted issue. European Journal of Operational Research 200, 2010. p. 629-638.

RUIJS, A., SCHWEIGMAN, C., LUTZ, C. The impact of transport - and transaction-cost reductions on food markets in developing countries: evidence for tempered expectations for Burkina Faso. Agricultural Economics, Elsevier, 2004. p. 219-228.

SANTOS, A.R. A grande barreira da Serra do Mar. São Paulo, O nome da rosa, 2004. p.122.

SAPHIRO, J.F. Modeling the supply chain. Pacific Groove CA: Duxbury press, 2001.

SIARMA, Sistema de informação de Armazenagem. Boletim informativo. Disponível em: <http://log.esalq.usp.br >. Acesso de: 01 set. 2013. 
SIFRECA, Sistema de informação de fretes de cargas agrícolas. Fretes Rodoviários. Disponível em: <http://log.esalq.usp.br >. Acesso de: 01 jan. a 05 set. 2012.

SOARES, M.G., CAIXETA-FILHO, J.V. Caracterização do mercado de fretes rodoviários para produtos agrícolas. Revista Gestão e Produção, v.4, n.2, ago, 1997. p. 186-204.

STERN, L., EL-ANSARY, A.I., COUGHLAN, A. Marketing Channels. $5^{\text {a }}$ Ed., Prentice-Hall, Englewood Clifs, NJ, 1996. p. 576.

V.I.S.A. Virtual Instrument Software Architecture. Disponível em: <http://www.visadecisions.com/index.php>. Acesso em: 01 set. 2013.

VALEC, Engenharia, Construções e Ferrovias S.A. Disponível em: <http://www.valec.gov.br>. Acesso em: 01 mar. 2013.

VALOR, Valor econômico: Governo zera até março de 2009 alíquota de IPI para os caminhões, dez, 2008. Disponível em: <http://www.valor.com.br >. Acesso em: 01 jul. 2013.

VENCOVSKY, V. P. Ferrovia e logística do agronegócio globalizado: Avaliação das políticas públicas e privadas do sistema ferroviário brasileiro. Tese (Doutorado). - Instituto de Geociências, Universidade Estadual de Campinas, Campinas, 2012.

VITA, B. Seguro de responsabilidade civil do transportador rodoviário de cargas aspectos jurídicos relevantes. Contratos e Obrigações Contratuais. Forense, Rio de Janeiro, 2001. p. 353.

WILliamson, O. E. Comparative Economic Organization: The Analysis of Discrete Structural Alternatives. Administrative Science Quarterly, 36, 1991. p. 93.

WILLIAMSON, O. E. The Economic institutions of capitalism: firms, markets, relational contracting. London: MacMillan Free Press, 1985.

WILliamSON, O. E. Transaction Costs Economics. The Netherlands: Ed Schamalensee, v. 1, cap.3, 1989. p. 135-182. 
YOSHIZAKI, H.T.Y. Projeto de redes de distribuição física considerando a influência do ICMS, Tese (Livre docência) - Escola Politécnica, Universidade de São Paulo, São Paulo, 2002.

ZYLBERSZTAJN, D. Estruturas de governança e Coordenação do Agribusiness: uma aplicação da Nova Economia das Instituições. Tese (Livre docência) Faculdade de Economia, Administração e Contabilidade, Universidade de São Paulo, São Paulo, 1995.

ZYLBERSZTAJN, D. Governance Structures and Agribusiness Coordination: A Transaction Cost Economics Based Approach. RESEARCH IN DOMESTIC AND INTERNATIONAL AGRIBUSINESS MANAGEMENT, Harvard University - USA, v. 12, 1996. p. 245-310.

ZYLBERSZTAJN, D., FARINA, E. Strictly coordinated food systems: exploring the limits of the coasian firm. International Food and Agribusiness Management Review, Vol. 2 No. 2, 1999. p. 249-265.

ZYLBERSZTAJN, D., NOGUEIRA, A.C.L. Estabilidade e difusão de arranjos verticais de produção: uma contribuição teórica. Economia e Sociedade. Campinas, v. 11, n. 2, f.19, 2002. p. 329-346. 


\section{ANEXO I}

\section{QUESTIONÁRIO SEMIESTRUTURADO:}

1. Como está desenhada a sua plataforma logística (região de atuação, volume transportado, gastos com frete, distância média transportada, produtos transportados)?

2. Quais os modelos de contratação do transporte utilizados?

3. Possui ativos de transporte rodoviário? Como é feita a operação/gestão dos ativos?

4. Fazem contratos de transporte com volume, preço e prazo fixados? Qual a frequência de negociação dos contratos?

5. Possui empresa transportadora para subcontratar o transporte? Qual a participação de principais benefícios?

\section{RESPOSTAS:}

\section{EMPRESA 1}

Multinacional de alta participação no mercado, possui alta participação na comercialização de grãos em todo país com armazéns, portos e fábricas. Transporta soja, milho, farelo, algodão, óleo vegetal envasado, óleo vegetal a granel, derivados de milho e de cacau, etanol e açúcar, entre outros, em uma distância média de 900 km, com um gasto anual de frete de mais de 1 bilhão de reais para mover mais de 10 milhões de toneladas/ano. Celebra contratos de curto, médio e longo prazo com transportadoras grandes, sendo o mais comum o contrato de safra que é negociado antecipadamente para o cumprimento das obrigações no período de fevereiro à abril. Também são realizados contratos anuais e mensais de acordo com o as cotações do mercado. A contratação spot é bastante relevante, mas a mesma é essencialmente realizada por transportadoras que já realizam um contrato formal. Não possui atualmente ativos rodoviários para transporte de grãos, mas possui empresa de transporte que realiza a subcontratação de empresas menores, atuando em pequena escala, através da captação de motoristas em pontos estratégicos. 


\section{EMPRESA 2}

Empresa brasileira com alta participação no centro-norte do país, possui armazéns, portos e fábricas próprios e realiza transporte de produtos agropecuários como soja, milho, farelo, óleo vegetal a granel, fertilizantes, algodão, entre outros. Sua distância média percorrida no transporte rodoviário para transportar mais de 5 milhões de toneladas/ano é de mais de $1.000 \mathrm{~km}$ e seus gastos com frete superam 500 milhões de reais. O transporte é essencialmente realizado através da contratação da empresa transportadora própria, que subcontrata terceiros através de sua rede de captação em pontos estratégicos. Não possui ativos rodoviários e a maior parte dos contratos são negociados no mercado spot com pequenos frotistas e autônomos. Pontualmente são realizados contratos de médio prazo com alguns frotistas grandes para atendimento durante um período crítico. Entre os benefícios de realizar a subcontratação de terceiros destaca-se que a proximidade com o motorista, acompanhamento do mercado de fretes e gestão da operação. Os riscos apontados são as responsabilidades assumidas que exigem muito cuidado até que o produto seja entregue no destino final.

\section{EMPRESA 3}

Embarcador multinacional com alta participação no centro-sul do país, possui portos, fábricas e armazéns próprios. Com uma conta frete de mais de 1 bilhão de reais, transporta de soja, milho, farelo, óleo vegetal a granel, fertilizantes, algodão, açúcar e etanol, derivados de cacau, entre outros, percorrendo com as suas mercadorias uma distância superior a $800 \mathrm{~km}$. Possuem alguns ativos rodoviários para transportar mais de 10 milhões de toneladas/ano. Possui empresa de transporte próprio que realiza a subcontratação de terceiros, sendo a participação com a frota própria muito pequena. $\mathrm{O}$ modelo mais comum é a verticalização parcial, onde o cavalo mecânico é terceirizado e o implemento é próprio; e neste caso existe um contrato de prestação de serviço que garante a exclusividade do transporte, mas nem volume e fretes são pré-definidos. A sua maior participação de contratação é no mercado spot, através das agências próprias com escritórios em pontos estratégicos.

\section{EMPRESA 4}

Multinacional de grande porte em todas as regiões do Brasil, com uma despesa logística superior a 1 bilhão de reais para transportar soja, milho, farelo, óleo vegetal a granel, 
óleo vegetal envasado, trigo e derivados, etanol e açúcar, fertilizantes, algodão, entre outros. Para movimentar mais de 10 milhões de toneladas, em uma distância média superior a $900 \mathrm{~km}$, a empresa conta com contratos de longo prazo com grandes transportadoras, contratação direta de autônomos e pequenos frotistas através de uma filial transportadora com escritórios nos principais pontos corredores de movimentação de cargas. Possui portos, fábricas e armazéns que movimentam um alto volume de cargas durante todo o ano. Já trabalhou com quase todos os modelos de operação rodoviária, desde da integração total em alguns segmentos até a total terceirização. Os contratos por ela operados somam uma parcela significativa da movimentação perene, e incluem a exclusividade de execução apenas com a frota própria. No mercado spot, a negociação é bem mais frequente, com contratação diária no mercado de terceiros e pequenos frotistas locais.

\section{EMPRESA 5}

Multinacional com grande atuação em todo o país, com menor expressão no corredor centro-norte, possuindo armazéns, fábricas e portos. Movimenta mais de 10 milhões de toneladas/ano, e gasta com fretes mais de 1 bilhão de reais por ano, a uma distância média de aproximadamente $1.000 \mathrm{~km}$. Não possui filial transportadora, executando contratações de safra, mensal e semanal dependendo da operação. Transporta soja, milho, farelo, óleo vegetal a granel, óleo vegetal envasado, trigo, etanol e açúcar, fertilizantes, algodão, entre outros. No mercado de transporte de grãos não possui ativos rodoviários e normalmente seus contratos são executados por transportadoras que trabalham em sua maioria através da subcontratação de terceiros; por isso, o mais comum é a contratação ser baseada no frete spot de mercado.

\section{EMPRESA 6}

Multinacional com atuação no centro-sul, com fábricas, portos e armazéns distribuídos em uma distância média de $800 \mathrm{~km}$ para ser transportado um volume superior a 5 milhões de toneladas e um gasto logístico em transporte rodoviário de mais de 5 milhões de reais. Com seu transporte de grãos totalmente terceirizado, movimenta soja, milho, farelo, óleo vegetal a granel, etanol e açúcar, algodão, entre outros. Os contratos de frete que negociam são efetuados principalmente em períodos de safra, onde é travado o preço do frete, volume e período e o transportador executa o transporte com 
frota própria e terceiros. Ao longo do ano, volumes, mensais, semanais também são acertados ao longo do ano, normalmente com os mesmos transportadores que executam o transporte durante a safra.

\section{EMPRESA 7}

Empresa multinacional com pequena expressão nas regiões onde atua, mas com grande amplitude na malha de atendimento, principalmente nas regiões centro-oeste, sudeste e nordeste. Possui fábricas e armazéns, mas opera com terminais terceiros em diversos portos do país, por onde movimenta um volume inferior a 3 milhões de toneladas de soja, milho, farelo, óleo vegetal a granel, entre outros. Cruza mais de $1.200 \mathrm{~km}$ em média e gasta menos de $\mathrm{R} \$ 300$ milhões em frete rodoviário por ano. Devido ao baixo volume movimentado, seu transporte é realizado por poucas transportadoras de grande porte, que conseguem ter atuação nacional e que executam o serviço com frota própria e terceiros. Não possui ativos no transporte rodoviário e não possui estruturas de contratação de terceiros devido à equipe ser pequena e centralizada, sem estar presente nas localidades onde o embarque é realizado.

\section{EMPRESA 8}

Multinacional com baixa participação de mercado nas regiões centro-sul, mas com diversidade nas operações de transporte de soja, milho, sementes, fertilizantes, entre outros. As despesas com frete giram na casa de 500 milhões de reais, para movimentar cerca de 5 milhões de toneladas por uma distância média de $1.300 \mathrm{~km}$ por ano. Possui apenas armazéns e sua operação portuária é executada em terminais terceiros. Contrata em sua maioria grandes transportadores que realizam o serviço prestado com frota própria e terceiros, mas também realiza em algumas localidades a contratação direta de autônomos, principalmente onde há regionalização e necessidade de acompanhamento do serviço de transporte com muito cuidado. Não possui ativos e nem contratos de longo prazo, sendo a contratação normalmente realizada com frequência semanal no mercado spot.

\section{EMPRESA 9}

Multinacional com expressão nacional na fabricação e distribuição de fertilizantes, possuindo fábricas e portos de onde são expedidas as mercadorias para todo o país. A 
distância média por onde transporta cerca de 5 milhões de toneladas é de aproximadamente $1.500 \mathrm{~km}$, o que gera um gasto de frete rodoviário superior a 500 milhões de reais. Não possui ativos para o transporte próprio, mas fazem contratos de transporte anual, mensal e semanal, principalmente com grandes transportadores. A contratação de terceiros ainda não é uma realidade, principalmente pela baixa visibilidade da operação principal (grãos), uma vez que a maior parte do transporte é fluxo de retorno.

\section{EMPRESA 10}

Empresa brasileira, com atuação principalmente no centro-oeste, que possui fábricas e armazéns, por onde expede soja, milho, farelo, fertilizantes, entre outros granéis sólidos agrícolas. Apesar de uma movimentação inferior a 3 milhões de toneladas e um gasto com frete inferior a 300 milhões de reais, possui uma frota própria e uma estrutura de transportadora para subcontratar motoristas terceiros. Atua também na contratação de grandes transportadores para alguns fluxos, mas não possui contratos de longo prazo, atuando principalmente na modalidade spot. Se estruturar na logística para melhor atender à demanda, e acompanhar de perto o mercado spot é uma grande vantagem, uma vez que sua atuação é regional e muitas vezes é possível aproveitar oportunidades como o frete de retorno em rotas longas.

\section{EMPRESA 11}

Fabricante multinacional de fertilizantes, que atua em todo o território nacional e movimenta menos de 5 milhões de toneladas com um gasto de frete inferior a 500 milhões de reais por ano, para cruzar em média mais de $1.300 \mathrm{~km}$. Possui contratação de fretes via transportadoras de grande porte que executam o serviço em boa parte com frota própria e também com terceiros. Como os fluxos normalmente são de frete de retorno com origem em suas fábricas e portos, o transportador prioriza a frota para o aproveitamento do retorno e melhora da produtividade dos veículos, que se atuassem na contratação do frete de retorno estariam mais sujeitos à variação do mercado spot. Já realizaram investimentos em aquisição de ativos que repassaram para terceiros operarem mediante arrendamento, mas não operam frota com funcionários próprios. 


\section{EMPRESA 12}

Empresa nacional com atuação principalmente no centro-sul, que transporta principalmente milho, soja e fertilizantes com origem principal em seus armazéns. Possui contratos de curto prazo e principalmente no mercado spot, onde realiza a contratação direta dos terceiros e pagando apenas o agenciamento dos motoristas para uma empresa local que faz a captação. Também possui uma frota própria que está crescendo, que é operada por funcionários e ativos da própria empresa e que se mostra como uma estratégia interessante de verticalização para reduzir os seus gastos com frete. A despesa anual com logística é inferior a 300 milhões de reais para movimentar menos de 3 milhões de toneladas/ano por uma distância média de aproximadamente $1.200 \mathrm{~km}$.

\section{EMPRESA 13}

Empresa nacional com participação principalmente na região sul, onde possui terminais portuários, fábricas e armazéns. Seu mix de transporte inclui o transporte principal de soja, milho e farelo, além do retorno com trigo e fertilizantes. Os gastos anuais com frete são inferiores a 300 milhões de reais, sendo o volume transportado de menos de 5 milhões de toneladas, que percorrem em média $500 \mathrm{~km}$. Para executar a sua logística a empresa possui uma frota expressiva de caminhões, também contrata diretamente autônomos e pequenos frotistas. Devido à atuação regional e à alta volatilidade do mercado, os contratos são baseados na exclusividade do ativo e, portanto, não executados com transportadores que subcontratam o transporte, somente com os frotistas. O restante da contratação é no mercado spot, e o frete é pago direto ao terceiro que já sai com o conhecimento de transporte diretamente do armazém.

\section{EMPRESA 14}

Empresa nacional com expressão no centro-oeste e sudeste, que transporta para suas fábricas, armazéns e portos soja, milho, farelo, óleo vegetal a granel, entre outros produtos. O volume anual movimentado é de aproximadamente 5 milhões de toneladas, que geram um custo com frete próximo a 500 milhões de reais/ano para se percorrer uma distância média de $800 \mathrm{~km}$. Possui contratação direta de autônomos e pequenos frotistas, além de contratar também grandes transportadores para atendimento em regiões mais distantes de sua área de atuação. Possui contratos de safra com frotistas, 
mas a principal modalidade de contratação é no mercado spot, devido à alta sazonalidade dos fretes em sua região. Não possui ativos de transporte rodoviário, mas a contratação direta permite uma proximidade muito grande com o dono do ativo, sendo esta especificidade negociada no transporte de suas mercadorias. 